Cochrane Database of Systematic Reviews

\title{
Dimercaptosuccinic acid scan or ultrasound in screening for vesicoureteral reflux among children with urinary tract infections
} (Review)

Shaikh N, Spingarn RB, Hum SW

Shaikh N, Spingarn RB, Hum SW.

Dimercaptosuccinic acid scan or ultrasound in screening for vesicoureteral reflux among children with urinary tract infections.

Cochrane Database of Systematic Reviews 2016, Issue 7. Art. No.: CD010657.

DOI: 10.1002/14651858.CD010657.pub2. 
TABLE OF CONTENTS

HEADER

ABSTRACT

PLAIN LANGUAGE SUMMARY

SUMMARY OF FINDINGS

BACKGROUND

OBJECTIVES

METHODS

RESULTS

Figure 1.

Figure 2.

Figure 3.

Figure 4.

Figure 5.

Figure 6.

Figure 7.

Figure 8.

Figure 9.

Figure 10.

Figure 11.

Figure 12.

Figure 13.

DISCUSSION

AUTHORS' CONCLUSIONS

ACKNOWLEDGEMENTS

REFERENCES

CHARACTERISTICS OF STUDIES

DATA

Test 1. Ultrasound.

Test 2. Ultrasound for high-grade VUR.

Test 3. Ultrasound Renal Units.

Test 4. Ultrasound for high-grade VUR (Renal Units).

Test 5. DMSA.

Test 6. DMSA for high-grade VUR.

Test 7. DMSA Renal-Units.

Test 8. DMSA for high-grade VUR (Renal Units).

APPENDICES

CONTRIBUTIONS OF AUTHORS

DECLARATIONS OF INTEREST

SOURCES OF SUPPORT

DIFFERENCES BETWEEN PROTOCOL AND REVIEW

INDEX TERMS 
[Diagnostic Test Accuracy Review]

\section{Dimercaptosuccinic acid scan or ultrasound in screening for vesicoureteral reflux among children with urinary tract infections}

Nader Shaikh¹, Russell B Spingarn², Stephanie W Hum ${ }^{1}$

1 General Academic Pediatrics, Children's Hospital of Pittsburgh, Pittsburgh, PA, USA. 2University of Pittsburgh School of Medicine, Pittsburgh, PA, USA

Contact address: Nader Shaikh, General Academic Pediatrics, Children's Hospital of Pittsburgh, 3414 Fifth Ave, Suite 301, Pittsburgh, PA, 15213, USA. Nader.Shaikh@chp.edu.

Editorial group: Cochrane Kidney and Transplant Group.

Publication status and date: New, published in Issue 7, 2016.

Citation: Shaikh N, Spingarn RB, Hum SW. Dimercaptosuccinic acid scan or ultrasound in screening for vesicoureteral reflux among children with urinary tract infections. Cochrane Database of Systematic Reviews 2016, Issue 7. Art. No.: CD010657. DOI: 10.1002/14651858.CD010657.pub2.

Copyright ( 2016 The Cochrane Collaboration. Published by John Wiley \& Sons, Ltd.

\section{A B S T R A C T}

\section{Background}

There is considerable interest in detecting vesicoureteral reflux (VUR) because its presence, especially when severe, has been linked to an increased risk of urinary tract infections and renal scarring. Voiding cystourethrography (VCUG), also known as micturating cystourethrography, is the gold standard for the diagnosis of VUR, and the grading of its severity. Because VCUG requires bladder catheterisation and exposes children to radiation, there has been a growing interest in other screening strategies that could identify atrisk children without the risks and discomfort associated with VCUG.

\section{Objectives}

The objective of this review is to evaluate the accuracy of two alternative imaging tests - the dimercaptosuccinic acid renal scan (DMSA) and renal-bladder ultrasound (RBUS) - in diagnosing VUR and high-grade VUR (Grade III-V VUR).

\section{Search methods}

We searched MEDLINE, EMBASE, BIOSIS, and the Cochrane Register of Diagnostic Test Accuracy Studies from 1985 to 31 March 2016. The reference lists of relevant review articles were searched to identify additional studies not found through the electronic search.

\section{Selection criteria}

We considered published cross-sectional or cohort studies that compared the results of the index tests (DMSA Scan or RBUS) with the results of radiographic VCUG in children less than 19 years of age with a culture-confirmed urinary tract infection.

\section{Data collection and analysis}

Two authors independently applied the selection criteria to all citations and independently abstracted data. We used the bivariate model to calculate summary sensitivity and specificity values.

\section{Main results}

A total of 42 studies met our inclusion criteria. Twenty studies reported data on the test performance of RBUS in detecting VUR; the summary sensitivity and specificity estimates were $0.44(95 \% \mathrm{Cl} 0.34$ to 0.54$)$ and 0.78 ( $95 \% \mathrm{Cl} 0.68$ to 0.86$)$, respectively. A total of 11 studies reported data on the test performance of RBUS in detecting high-grade VUR; the summary sensitivity and specificity estimates were 0.59 ( $95 \% \mathrm{Cl}$ 0.45 to 0.72$)$ and $0.79(95 \% \mathrm{Cl} 0.65$ to 0.87$)$, respectively. A total of 19 studies reported data on the test performance of DMSA in detecting VUR; the summary sensitivity and specificity estimates were $0.75(95 \% \mathrm{Cl} 0.67$ to 0.81$)$ and $0.48(95 \% \mathrm{Cl} 0.38$ to 0.57$)$, respectively. A total 
of 10 studies reported data on the accuracy of DMSA in detecting high-grade VUR. The summary sensitivity and specificity estimates were $0.93(95 \% \mathrm{Cl} 0.77$ to 0.98$)$ and $0.44(95 \% \mathrm{Cl} 0.33$ to 0.56$)$, respectively.

\section{Authors' conclusions}

Neither the renal ultrasound nor the DMSA scan is accurate enough to detect VUR (of all grades). Although a child with a negative DMSA test has an $<1 \%$ probability of having high-grade VUR, performing a screening DMSA will result in a large number of children falsely labelled as being at risk for high-grade VUR. Accordingly, the usefulness of the DMSA as a screening test for high-grade VUR should be questioned.

\section{PLAIN LANGUAGE SUMMARY}

\section{The accuracy of two imaging tests in detecting vesicoureteral reflux}

Some children are born with an anatomic abnormality that allows backwards flow of urine from the bladder to the kidney. This is called vesicoureteral reflux or VUR. Children with VUR have more urinary tract infections and develop more renal scars than children without VUR. This is especially the case if VUR is severe. As such, clinicians are interested in finding out which children have VUR. Unfortunately, testing for VUR (using a voiding cystourethrogram or a VCUG or MCUG) involves bladder catheterisation and exposure to radiation. Accordingly, clinicians are interested in finding alternative tests that could replace the VCUG. The authors compared the accuracy of two other imaging tests (ultrasound and DMSA renal scan) to see whether these could replace the VCUG test. Neither test was found to be sufficiently accurate to replace the VCUG test. Although the DMSA scan seems to be good at ruling out high-grade VUR, it falsely labels many children as being at risk for high-grade VUR. Accordingly, DMSA does not appear to be useful as a screening test. 


\section{S U M MARY OF F I N D I N S}

Summary of findings 1. Renal-bladder ultrasound (RBUS) and 99Tc-Dimercaptosuccinic acid (DMSA) in the detection of vesicoureteral reflux (VUR)

Accuracy of RBUS and DMSA in detecting VUR in a population of 1000 children*

Population: 1000 children with urinary tract infection (UTI) of which 400 have VUR

Setting: not specified

Tests: DMSA conducted within 1 month of the diagnosis of UTI, RBUS

Reference test: radiographic voiding cystourethrogram

\begin{tabular}{|c|c|c|c|c|c|c|c|c|c|}
\hline $\begin{array}{l}\text { Test and } \\
\text { cut-off }\end{array}$ & $\begin{array}{l}\text { No. of stud- } \\
\text { ies (partici- } \\
\text { pants) }\end{array}$ & $\begin{array}{l}\text { Summary Sensitivity } \\
(95 \% \mathrm{Cl})\end{array}$ & $\begin{array}{l}\text { Summary Specificity } \\
(95 \% \mathrm{Cl})\end{array}$ & $\begin{array}{l}\text { No. with a } \\
\text { false neg- } \\
\text { ative test } \\
\text { (missed cas- } \\
\text { es) }\end{array}$ & $\begin{array}{l}\text { No. with a } \\
\text { false positive } \\
\text { test (over-di- } \\
\text { agnosed) }\end{array}$ & $\begin{array}{l}\text { Post-test } \\
\text { probability of } \\
\text { VUR given a } \\
\text { positive test }\end{array}$ & $\begin{array}{l}\text { Post-test } \\
\text { probability of } \\
\text { VUR given a } \\
\text { negative test }\end{array}$ & $\begin{array}{l}\text { Hetero- } \\
\text { geneity } \\
\text { between } \\
\text { studies }\end{array}$ & $\begin{array}{l}\text { High risk } \\
\text { of bias } \\
\text { studies }\end{array}$ \\
\hline $\begin{array}{l}\text { Ultra- } \\
\text { sound }\end{array}$ & $20(3726)$ & $0.44(0.34$ to 0.54$)$ & 0.78 (0.68 to 0.86$)$ & 224 & 132 & $57 \%$ & $32 \%$ & High & 13 of 20 \\
\hline DMSA & $19(3863)$ & 0.75 (0.67 to 0.81$)$ & 0.48 (0.38 to 0.57$)$ & 100 & 312 & $49 \%$ & $26 \%$ & Moderate & 10 of 19 \\
\hline
\end{tabular}

\section{Summary of findings 2. Renal-bladder ultrasound (RBUS) and 99Tc-Dimercaptosuccinic acid (DMSA) in the detection of high-grade vesicoureteral} reflux (VUR) (VUR III-V)

Accuracy of RBUS and DMSA in detecting high-grade VUR in a population of 1000 children

Population: 1000 children with urinary tract infection (UTI) of which 130 have VUR III-V

Setting: not specified

Tests: DMSA conducted within 1 month of the diagnosis of UTI, RBUS

Reference test: radiographic voiding cystourethrogram

\begin{tabular}{|c|c|c|c|c|c|c|c|c|}
\hline $\begin{array}{l}\text { Test and } \\
\text { cut-off }\end{array}$ & $\begin{array}{l}\text { No. of } \\
\text { studies }\end{array}$ & $\begin{array}{l}\text { Summary Sen- } \\
\text { sitivity }(95 \% \mathrm{Cl})\end{array}$ & $\begin{array}{l}\text { Summary } \\
\text { Specificity (95\% } \\
\text { Cl) }\end{array}$ & $\begin{array}{l}\text { No. with a } \\
\text { false neg- } \\
\text { ative test }\end{array}$ & $\begin{array}{l}\text { No. with a } \\
\text { false pos- } \\
\text { itive test }\end{array}$ & $\begin{array}{l}\text { Post-test probability } \\
\text { of high-grade VUR giv- } \\
\text { en a positive test }\end{array}$ & $\begin{array}{l}\text { Post-test probability } \\
\text { of high-grade VUR giv- } \\
\text { en a negative test }\end{array}$ & $\begin{array}{l}\text { High risk } \\
\text { of bias } \\
\text { studies }\end{array}$ \\
\hline
\end{tabular}




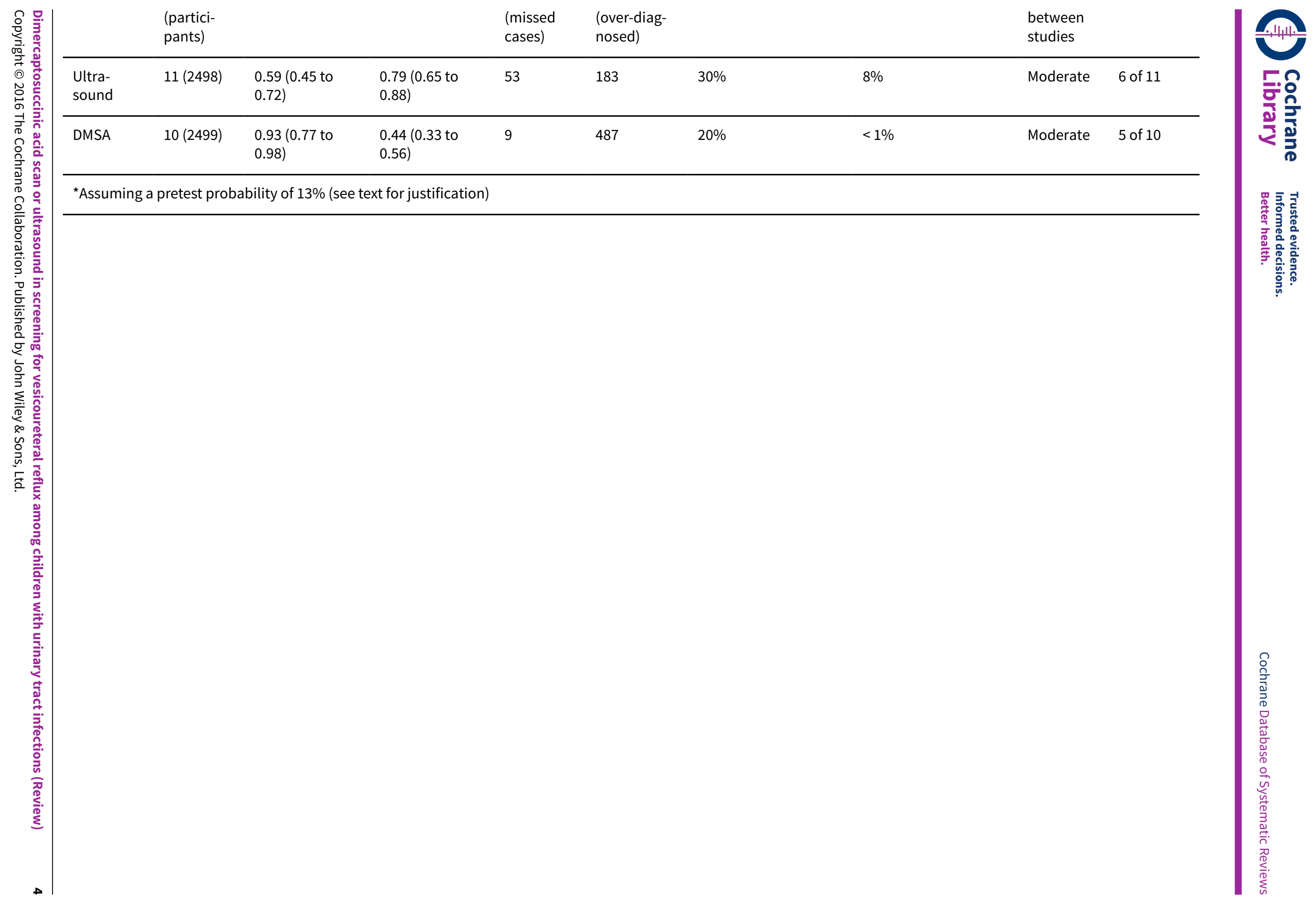




\section{B A C K G R O U N D}

Although the prevention of permanent renal scarring represents the ultimate goal of management strategies for childhood urinary tract infection (UTI), controversy exists about how this should be achieved. Until recently, the prevailing management approach in the United States has focused on the identification and treatment of the subset of children with vesicoureteral reflux (VUR), a congenital anatomic abnormality that enables retrograde flow of urine from the bladder to the kidney and therefore is thought to facilitate the ascent of infection to the kidney.

Voiding cystourethrography (VCUG), also known as micturating cystourethrography, is the gold standard for the diagnosis of VUR and the grading of its severity. During the VCUG the child is catheterized, and radiocontrast material is used to fill the bladder. The child is then asked to void (younger children often void automatically). Fluoroscopy is used to visualize the anatomy of the bladder and the urethra. Movement of the contrast medium into the ureters indicates VUR. VUR is graded on scale of I to V, with $V$ being the most severe. Grade III-V VUR is considered high-grade and may be present in up to $13 \%$ of children with febrile UTIs (Shaikh 2014).

Until recently, children with UTI underwent routine VCUG examinations and those with VUR were treated with prophylactic antibiotics and/or surgery. Increasingly, however, it has been recognized that the aggressive detection and treatment of VUR may not lead to improvements in long-term outcomes (Nagler 2011). Nevertheless, there is still considerable interest in detecting VUR, especially VUR that is severe. The Swedish reflux study showed that antibiotic treatment of girls with high-grade VUR was associated with significantly fewer infections and reduced renal scarring compared with placebo (Brandstrom 2010). A recent meta-analysis found that the prevalence of renal scarring was 2.6 times $(95 \% \mathrm{Cl} 1.7$ to 3.9) higher among children with VUR than among children with no VUR (41\% versus 17\%; $P=0.001$ ) (Shaikh 2010). The RIVUR study found that prophylactic antibiotics halved the rate of reinfection in children with VUR (Hoberman 2014). The American Academy of Pediatrics (AAP) guidelines recommend that children aged from 2 to 24 months with recurrent UTIs should be screened for VUR with a VCUG (AAP 2011). The United Kingdom's National Institute for Health and Care Excellence (NICE) guidelines recommend obtaining a VCUG in infants younger than six months of age with recurrent UTI (NICE 2007).

\section{Index test(s)}

One approach that has been advocated as an alternative to VCUGs is the performance of ${ }^{99} \mathrm{Tc}$-Dimercaptosuccinic acid (DMSA) renal scans within two weeks of the UTI. In this test, radiolabelled DMSA is injected through an IV catheter and DMSA uptake by the kidneys is visualized with a gamma camera approximately two hours later, enabling the radiologist to see the uptake of DMSA by different parts of the kidney. If tubular cell function is impaired because of pyelonephritis, the scan will show photon-deficient areas. A second approach is to use the renal-bladder ultrasound (RBUS) as a screening test for VUR. RBUS is useful for detecting a variety of anatomic abnormalities, but its accuracy in diagnosing VUR or highgrade VUR has not been systematically studied.

\section{Clinical pathway}

Although guidelines vary, most young children with UTI will have a routine RBUS performed soon after the first UTI. VCUG is usually reserved for children with an abnormal RBUS or children with multiple UTIs. If VUR is detected, controversy exists regarding which children, if any, should be treated with prophylactic antibiotics and or surgery. VUR resolves spontaneously and without sequelae in the large majority of children. DMSAs are not routinely performed in children with UTIs.

\section{Alternative test(s)}

Several other tests, such as inflammatory markers (e.g. procalcitonin) have been recently proposed as alternatives to VCUG. However, because they have been reviewed elsewhere, they were not considered here.

\section{Rationale}

Because VCUG requires bladder catheterization, there has been growing interest in other screening strategies that could identify at-risk children without the risks and discomfort associated with VCUG. Both DMSA and RBUS have been put forth as possible tests that could replace the VCUG in the detection of VUR. A systematic literature review on this topic will help clinicians to decide if a DMSA or a RBUS is an appropriate initial screening test for concerns regarding the presence of VUR.

\section{O B J E C T IVES}

The primary objective of this review is to evaluate the diagnostic accuracy of DMSA and RBUS in identifying VUR and high-grade VUR.

\section{Secondary objectives}

A secondary objective is to compare the rate of adverse events between DMSA scans and RBUS.

\section{METHODS}

\section{Criteria for considering studies for this review}

\section{Types of studies}

Cross-sectional and cohort designs were acceptable for inclusion. We excluded case-control studies because they are known to inflate estimates of sensitivity and specificity.

\section{Participants}

We considered published studies that compared the results of an index test (DMSA scan or RBUS) with the results of a radiographic VCUG in children from zero to 19 years of age with a cultureconfirmed episode of UTI. Studies were considered whether or not they included children with previous UTIs. UTI was defined as growth of $\geq 10^{4}$ colony-forming units $(\mathrm{CFU}) / \mathrm{mL}$ organisms from a catheterized specimen, $\geq 10^{5} \mathrm{CFU} / \mathrm{mL}$ organisms from a clean catch, midstream, or bag specimen, or any growth from a suprapubic specimen (Hoberman 1994). Studies that did not meet these minimum criteria were excluded.

\section{Index tests}

Studies in which DMSA scan was performed were included only if the DMSA was conducted within the first month of the UTI diagnosis. Planar DMSA scans are two-dimensional images of 
the distribution of radioisotope uptake, whereas SPECT (singlephoton emission computed tomography) DMSA scans reconstruct the three-dimensional distribution by taking multiple images from different angles. For the purpose of this analysis, any photopenia on a DMSA scan, with or without loss of contours, was considered positive. Studies in which RBUS was performed for the evaluation of UTI were included regardless of whether or not the timing of the RBUS was specified in the manuscript. Almost all centres we are aware of conduct the RBUS within the first two months after the diagnosis of a UTI. An ultrasound with any abnormality was considered positive.

\section{Target conditions}

VUR (any grade) and high-grade VUR (VUR grades III to V) were the target conditions.

\section{Reference standards}

VCUG is the reference standard for diagnosing VUR. VUR is graded from I to $V$ according to the International Reflux Study criteria (IRSC 1981); Grades III to V are considered high-grade.

\section{Search methods for identification of studies}

\section{Electronic searches}

We searched MEDLINE (OvidSP) to 31 March 2016 and EMBASE (OvidSP), BIOSIS, and the Cochrane Register of Diagnostic Test Accuracy Studies up to 6 February 2014. DMSA scans were not used in children until the late 1980s and ultrasound technology has improved greatly since the late 1980 's, so searches were limited to the years 1985 to the present.

See Appendix 1 for search strategies.

\section{Searching other resources}

1. Reference lists of important review articles retrieved from searches.

2. Reference lists of relevant diagnostic test accuracy studies.

\section{Data collection and analysis}

Two authors independently applied the selection criteria to all citations (titles and abstracts).

\section{Selection of studies}

Two authors independently assessed titles, abstracts and, if necessary, the full text of studies found using the search strategy to determine which studies satisfied the inclusion criteria. Disagreements were resolved by discussion.

\section{Data extraction and management}

Data extraction was carried out independently by two authors using standardized data extraction forms. When possible, study authors were contacted for clarification. Studies not published in English were translated before assessment. Where more than one publication of one study existed, reports were grouped together and the publication with the most complete data was used in the analyses.

For each study meeting our inclusion criteria, we abstracted the following information.
- Setting of enrolment (outpatient, emergency department, inpatient)

- Referral source (self-referred, referred by a specialist)

- Age range of participants

- Excluded children with genitourinary abnormalities? (yes, no)

- Excluded children with previous UTI? (yes, no)

- All children in study febrile (whether measured or tactile)? (yes, no)

- Used paediatric urine collection bags to collect urine specimen? (yes, no)

- Maximal delay in DMSA scan (within one week, one to two weeks, two to four weeks)

- Type of DMSA (planar versus. SPECT)

- Rate and type of adverse events from DMSA scan or RBUS.

Two by two tables were constructed independently by each author from the data in the publication. Only studies for which two by two data were available (or could be reconstructed) were included. Disagreements between authors were resolved by discussion.

\section{Assessment of methodological quality}

Two authors independently assessed the methodological quality of each included study using a four-domain tool (patient selection, the index test, the reference standard, and flow/timing) adapted from QUADAS-2 (Whiting 2011). QUADAS-2 is a validated tool specifically designed for review authors to evaluate quality of diagnostic accuracy studies. We adapted QUADAS-2 specifically for our review (see Appendix 2).

\section{Statistical analysis and data synthesis}

The primary analysis compared the accuracy of each index test (DMSA or RBUS) with the VCUG in the diagnosis of VUR of any grade. Because high-grade VUR (Grades III to V) is associated with a higher risk of scarring (Shaikh 2010), a secondary analysis was performed using high-grade VUR as the outcome.

For the analysis, we chose the bivariate model because we felt that studies mostly used uniform thresholds (any abnormality for RBUS and any photopenia for DMSA). In the bivariate model, the logittransformed sensitivity and specificity for each study are modelled jointly, and the correlation between them, across studies, is also taken into account. This method provides a summary estimate of sensitivity and specificity for each index test, along with a $95 \%$ confidence interval $(95 \% \mathrm{Cl})$. Results are then transformed back to the original scale and plotted in the ROC space.

We compared the index tests indirectly and directly. In the indirect comparison, we used the bivariate model to calculate summary sensitivity and specificity values separately for each test using data from all studies using test type as a covariate. Some studies directly compared (Hayen 2010) the accuracy of the two index tests (both index tests were performed in the same study); analysis of such studies may be less subject to bias.

$\mathrm{SAS}^{\oplus}$ software was used to perform all analyses.

\section{Investigations of heterogeneity}

We conducted a meta-regression to investigate heterogeneity in diagnostic accuracy across studies. We chose five variables a priori that we felt could explain some of the of heterogeneity. Each 
variable was included in the analysis as a study-level covariate and its effect on sensitivity and specificity was examined. This investigation was only performed if there were at least 10 studies (and least four studies for each category of the covariate).

The five covariates chosen are listed below. Two of the covariates are only applicable for studies of DMSA scan accuracy.

- All studies: whether or not fever was required for inclusion

- All studies: whether or not children with UTI diagnosed from a perineal bag collected specimen were included (because specimens obtained using a perineal bag have a high false positive rate)

- All studies: number of UTIs prior to enrolment ( 0 versus $\geq 1$ ) (because children with recurrent UTIs are more likely to have VUR)

- Studies of DMSA scan accuracy: timing of DMSA scan (<14 days versus < 30 days) after diagnosis of UTI (because DMSA scan sensitivity decreases substantively after two weeks (Stokland 1996))
- Studies of DMSA scan accuracy: whether a planar or a SPECT technique for the DMSA scan was used (because SPECT DMSA scans have lower specificity than planar DMSA scans (Craig 2000)).

\section{Sensitivity analyses}

To investigate robustness of the results we limited the analysis to 1 ) only studies at low risk of bias (QUADAS-2, item), and 2) only studies with no applicability concerns.

\section{RE S U L T S}

\section{Results of the search}

The results of the search strategy are shown in Figure 1. Of the 2778 articles found through the search strategy, 238 full text articles were retrieved and reviewed. A total of 42 studies met all the inclusion criteria, and all were included in the meta-analysis. 30/42 (71\%) studies enrolled only children with a first UTI, and 27/42 (64\%) studies enrolled only children with a fever. In studies in which DMSA scan was performed, 25/28 (89\%) conducted the scan within 14 days of UTI diagnosis, and all but one used planar DMSA imaging. 
Figure 1. Study flow diagram.

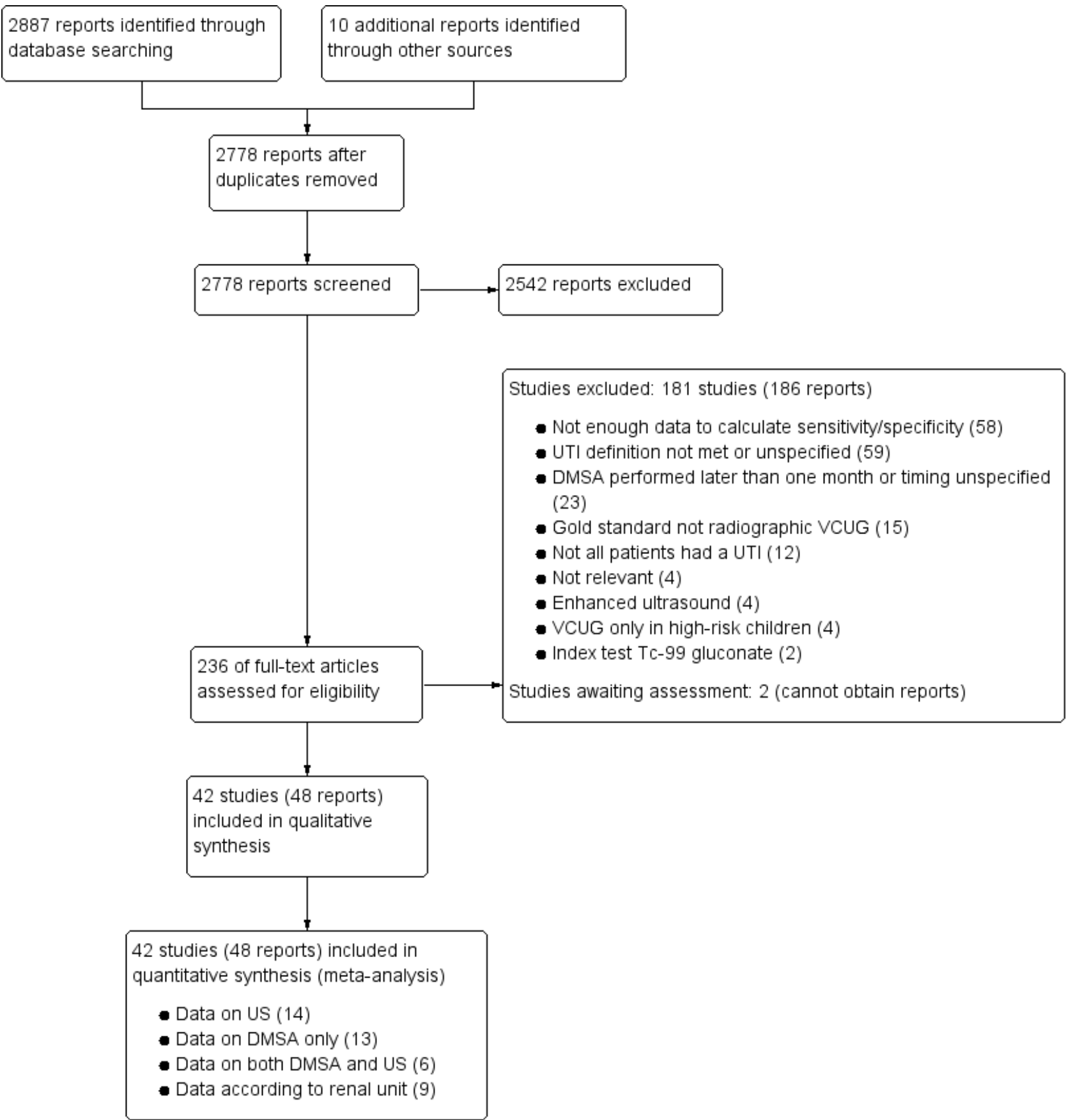

Data on the accuracy of ultrasound and DMSA in detecting VUR were available from 20 and 19 studies, respectively; six studies provided data on both tests. Data on the accuracy of ultrasound and DMSA in detecting high-grade VUR were available from 11 and 10 studies, respectively. Only one study included data on the accuracy of ultrasound at the level of the renal unit. Nine studies included data on the accuracy of DMSA in detecting VUR at the level of the renal unit; four of these provided data on high-grade VUR. A listing of the excluded studies and their characteristics is provided in Characteristics of excluded studies.

Prior to publication a final search (31 March 2016) was conducted. The references identified will be assessed in a future update of this review.

\section{Methodological quality of included studies}

The largest methodological limitations of the included studies are related to the selection of the patients (Figure 2; Figure 3). Of the 42 studies included, we judged that patient selection led to increased risk of bias in $11(26 \%)$ and to applicability concerns in $21(50 \%)$. We had relatively little concerns with regards to the way the reference standard was performed. Flow and timing issues were noted in four studies. Overall, there were concerns with risk of bias 
in the figures include the use of paediatric urine collection bags in 10 studies (23\%).

Figure 2. Risk of bias and applicability concerns graph: review authors' judgements about each domain presented as percentages across included studies

Patient Selection

Reference Standard

Flow and Timing

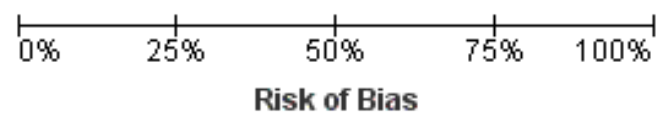

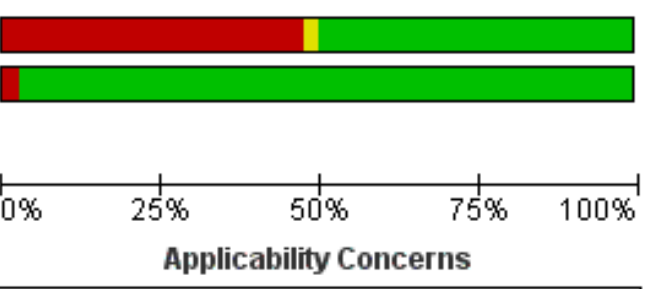

Low 
Figure 3. Risk of bias and applicability concerns summary: review authors' judgements about each domain for each included study

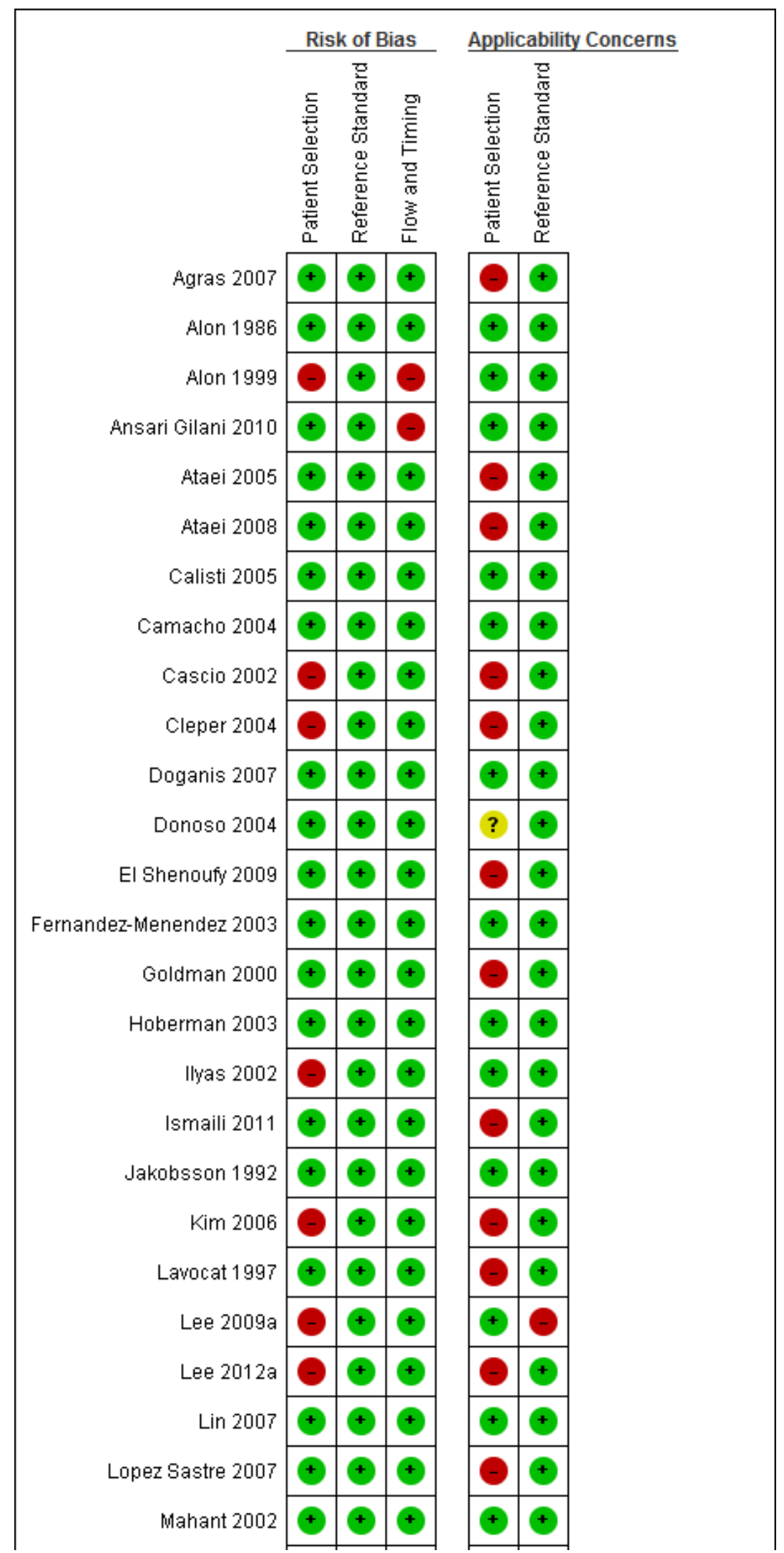

Dimercaptosuccinic acid scan or ultrasound in screening for vesicoureteral reflux among children with urinary tract infections (Review) 
Figure 3. (Continued)

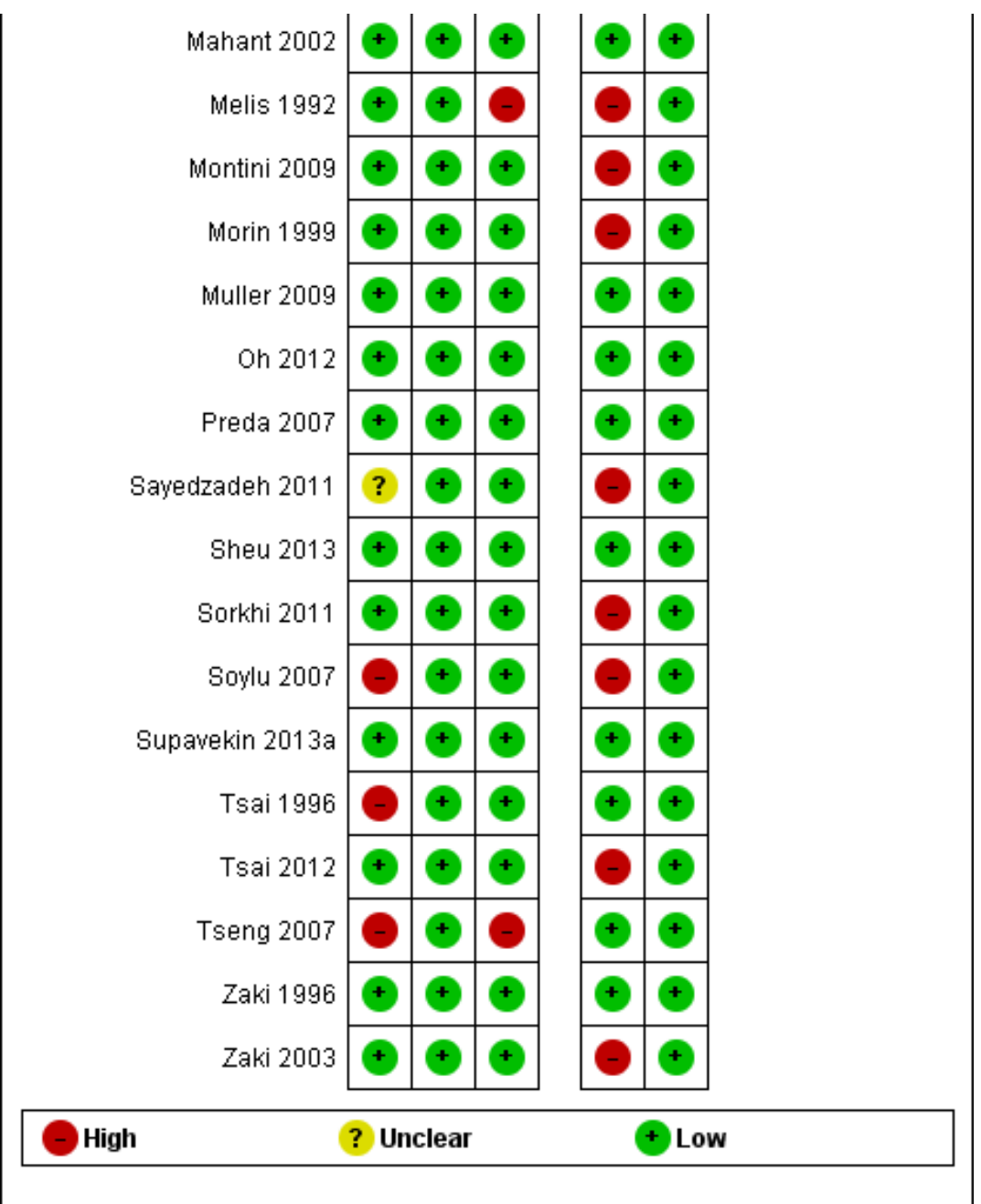

\section{Findings}

\section{Ultrasound}

Twenty studies reported data on the accuracy of ultrasound in detecting VUR. The summary sensitivity and specificity estimates were $0.44(95 \% \mathrm{Cl} 0.34$ to 0.54$)$ and $0.78(95 \% \mathrm{Cl} 0.68$ to 0.86 ), respectively (Figure 4). Although there was substantial heterogeneity between studies (Data table 1), none of the studies reported high sensitivity and specificity values. None of the covariates investigated in the meta-regression had a significant effect on either the sensitivity or specificity values. Limiting the analysis to low risk of bias studies resulted in an even lower summary specificity value $(0.72,95 \% \mathrm{Cl} 0.59$ to 0.82$)$. 
Figure 4. Ultrasound to detect VUR (all grades)

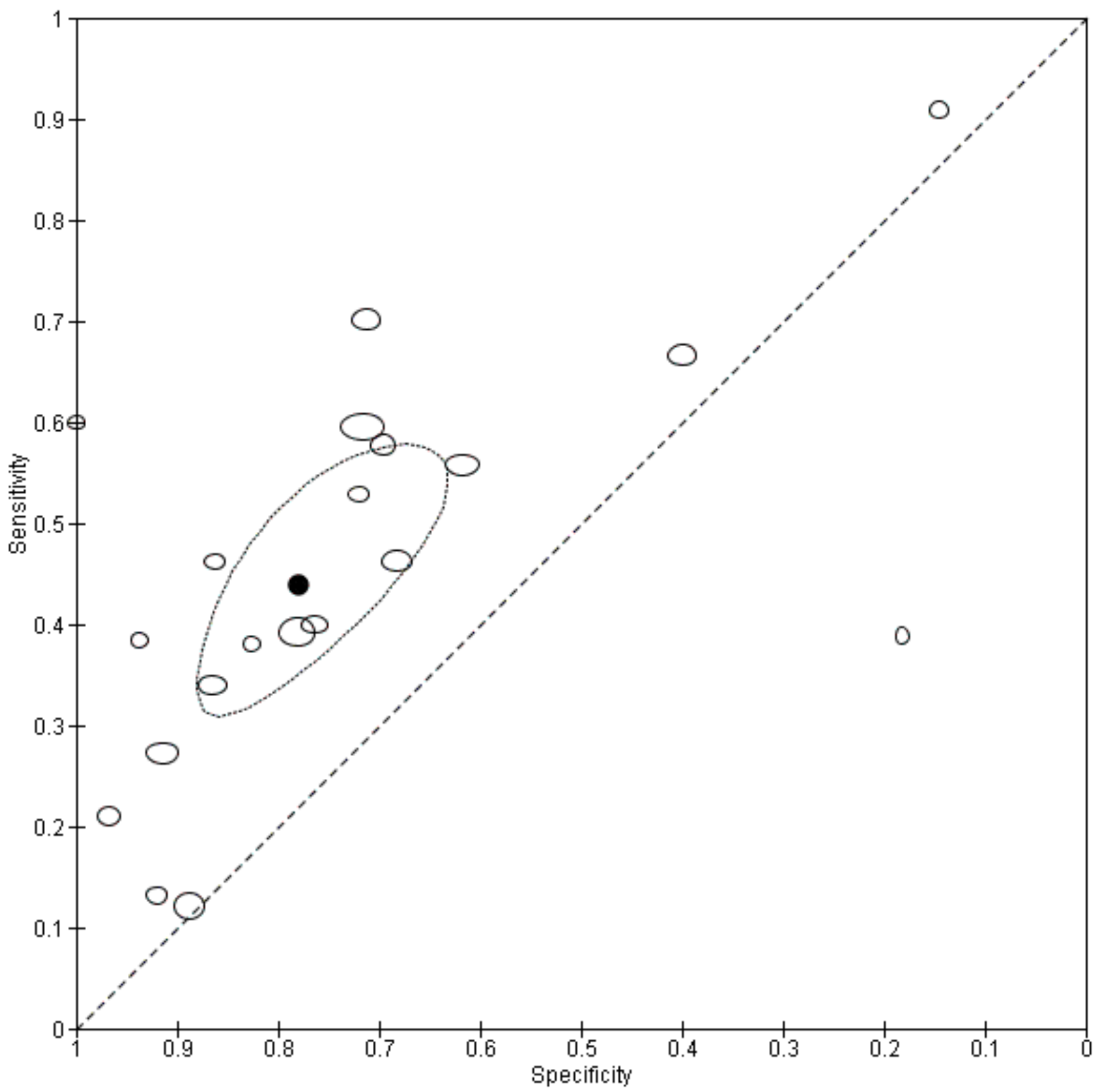

Eleven studies reported data on the accuracy of ultrasound in detecting high-grade VUR. The summary sensitivity and specificity estimates were $0.59(95 \% \mathrm{Cl} 0.45$ to 0.72$)$ and $0.79(95 \% \mathrm{Cl} 0.65$ to 0.87 ), respectively (Figure 5). Although there was substantial heterogeneity between studies (Data table 2), only Kim 2006 reported sensitivity and specificity values close to $90 \%$. The use of paediatric urine collection bags explained some of the heterogeneity in the sensitivity estimates $(P=0.045)$; the sensitivity of ultrasound in studies where paediatric urine collection bags were and were not used was $0.78(95 \% \mathrm{Cl} 0.55$ to 0.91$)$ and $0.49(95 \% \mathrm{Cl}$ 0.33 to 0.66 ), respectively. Sensitivity analysis did not substantively alter the summary estimates. 
Figure 5. Ultrasound to detect high-grade VUR

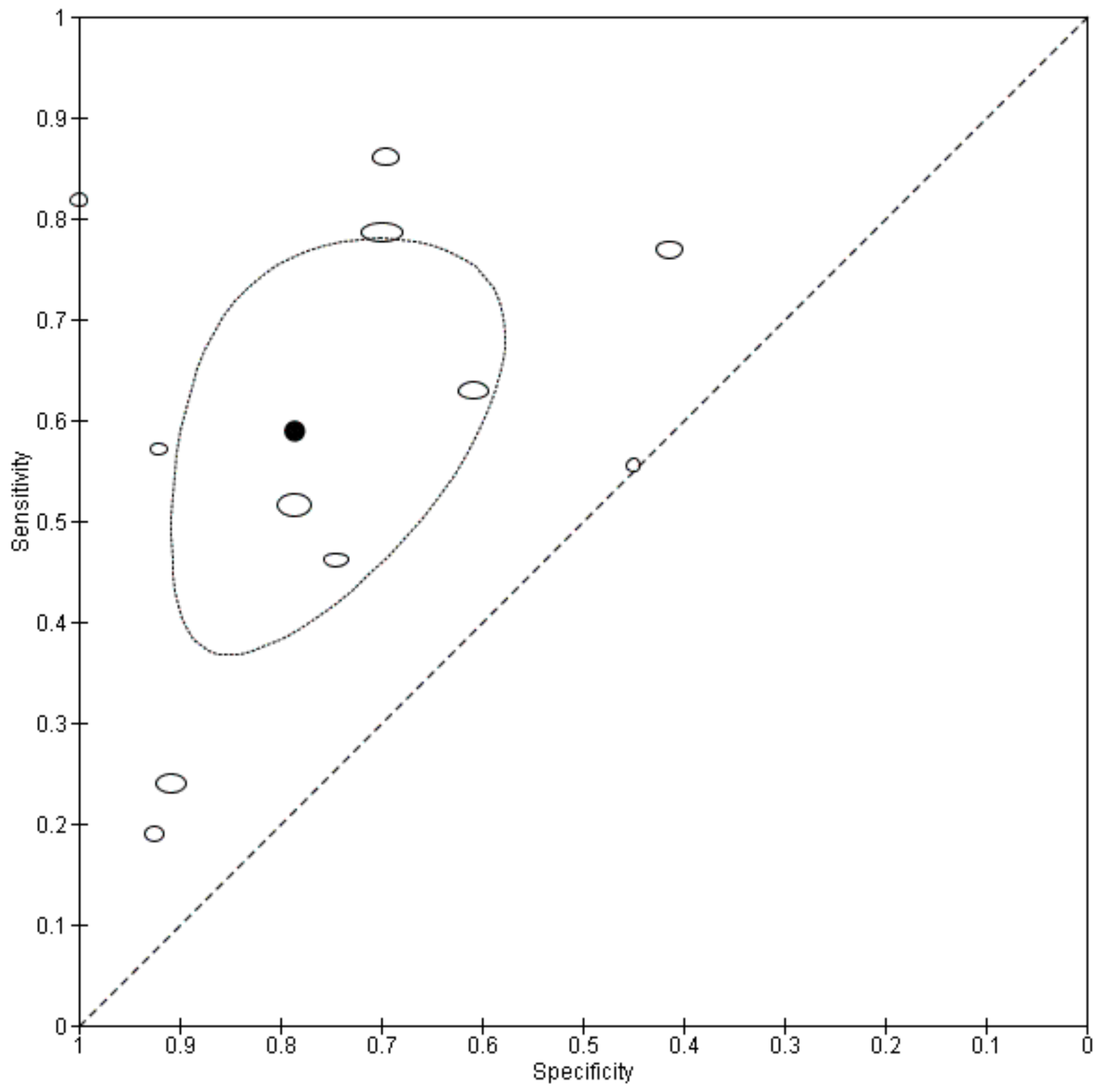

Only one study reported data according to renal units (Sorkhi 2011). This study found a sensitivity and specificity value of 0.30 and 0.84 in detecting VUR, respectively (Data table 3 ). The corresponding values for high-grade VUR were 0.29 and 0.81 (Data table 4).

\section{DMSA}

Nineteen studies reported data on the accuracy of DMSA in detecting VUR. The summary sensitivity and specificity estimates were $0.75(95 \% \mathrm{Cl} 0.67$ to 0.81$)$ and $0.48(95 \% \mathrm{Cl} 0.38$ to 0.57 ), respectively (Figure 6). However, substantial heterogeneity between the accuracy values limits our confidence in these summary estimates (Data table 5). Nevertheless, no study reported a specificity value close to $90 \%$. Exclusion of children with a previous UTI explained some of the heterogeneity between estimates; the specificity of DMSA in studies of children with a first UTI $(0.52,95 \% \mathrm{Cl} 0.42$ to 0.62$)$ was higher $(P=0.031)$ than in studies in which children with $>1$ UTI were included $(0.24,95 \% \mathrm{Cl} 0.11$ to 0.47$)$. Inclusion of afebrile children was another factor that explained some of the heterogeneity between studies; the sensitivity of DMSA in studies that included only febrile children $(0.72,95 \% \mathrm{Cl} 0.64$ to 0.78$)$ was lower $(P=0.037)$ than in studies which included afebrile children $(0.88,95 \% \mathrm{Cl} 0.74$ to $0.95)$. Sensitivity analysis did not substantively alter the summary estimates. 
Figure 6. DMSA to detect VUR (all grades)

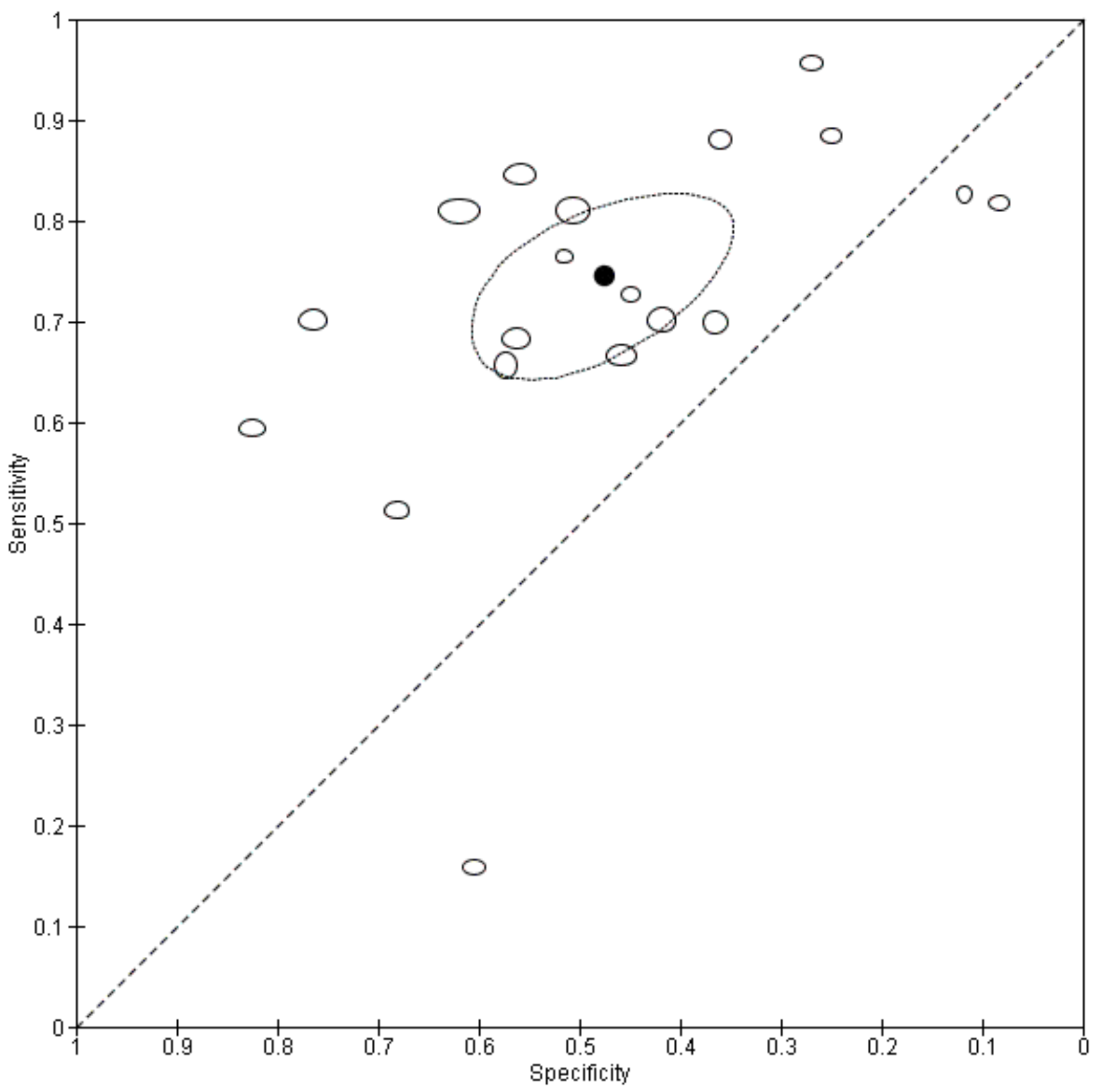

Ten studies reported data on the accuracy of DMSA in detecting high-grade VUR. The summary sensitivity and specificity estimates were $0.93(95 \% \mathrm{Cl} 0.77$ to 0.98$)$ and $0.44(95 \% \mathrm{Cl} 0.33$ to 0.56 ), respectively (Figure 7). However, substantial heterogeneity between the specificity values limits our confidence in these summary measures (Data table 6). Two studies (Agras 2007; Hoberman 2003 ) reported sensitivity values that were clearly lower than the rest of the studies. The inclusion of afebrile children explained some of the heterogeneity in the specificity values; the specificity of the DMSA scan in studies which included only febrile children $(0.52,95 \% \mathrm{Cl} 0.40$ to $0.64 ; \mathrm{P}=0.026)$ was higher $(\mathrm{p}=0.026)$ than in studies which included afebrile children $(0.27,95 \% \mathrm{Cl} 0.15$ to 0.45 ). Limiting the analysis to low risk of bias studies did not substantively alter the summary estimate; limiting the analysis to studies with no applicability concerns resulted in slightly lower specificity values $(0.34,95 \% \mathrm{Cl} 0.26$ to 0.43$)$. 
Figure 7. DMSA to detect high-grade VUR

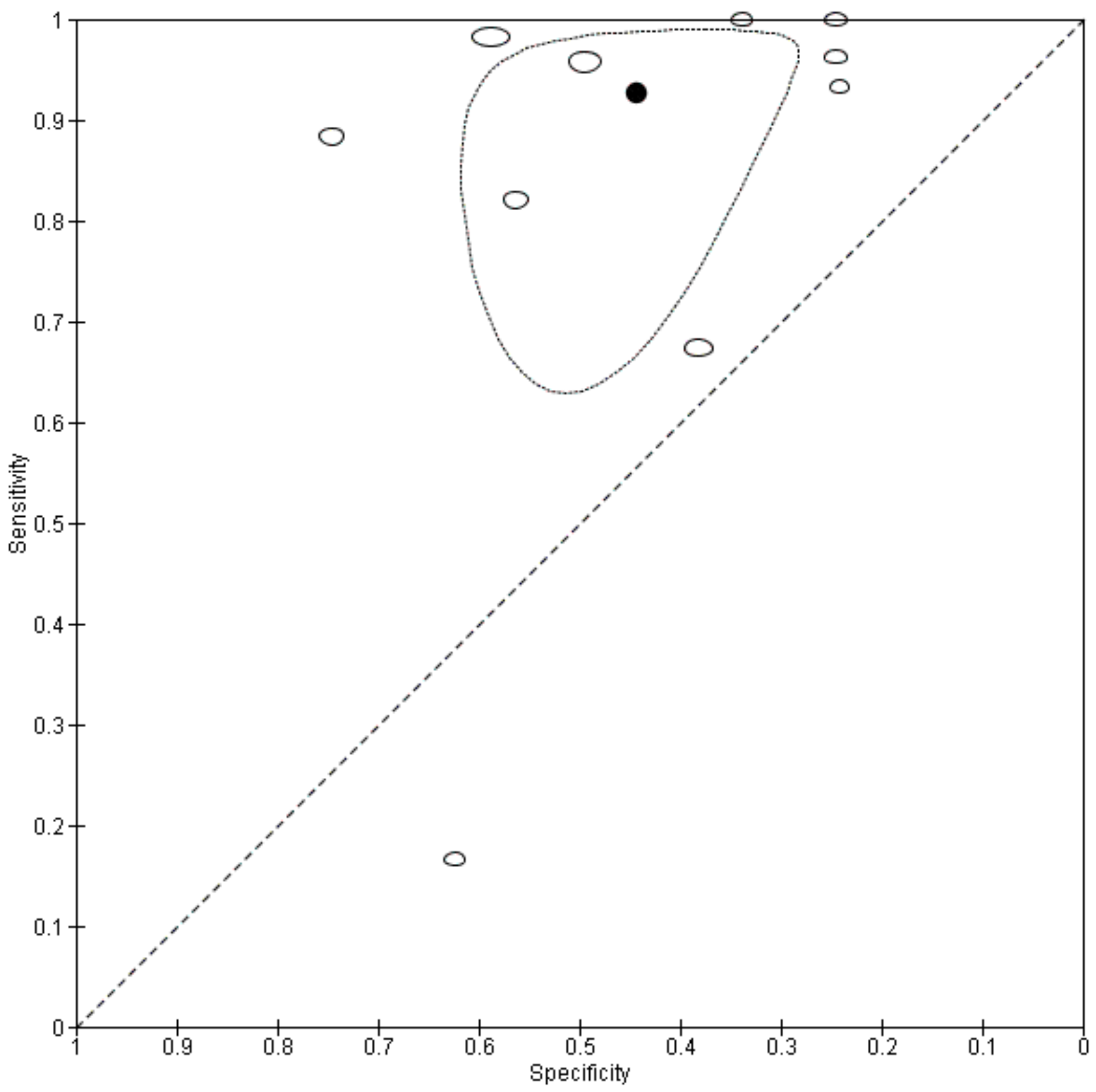

Nine studies reported data regarding the accuracy of DMSA in predicting VUR according to renal units. The summary sensitivity and specificity estimates were $0.72(95 \% \mathrm{Cl} 0.59$ to 0.82$)$ and 0.56 ( $95 \% \mathrm{Cl} 0.40$ to 0.40 ), respectively (Figure 8 ), However, substantial heterogeneity between the accuracy values limits our confidence in the summary accuracy measures (Data table 7). Because of the small number of studies, meta-regression could not be performed for the covariate relating to the use of paediatric urine collection bags. The inclusion of children with previous UTIs or the inclusion of afebrile children did not explain a significant proportion of the heterogeneity. Limiting the analysis to studies at high risk of bias or with concerns regarding applicability resulted in significantly lower specificity values $(0.48,95 \% \mathrm{Cl} 0.33$ to 0.63$)$. 
Figure 8. DMSA to detect renal units with VUR (all grades)

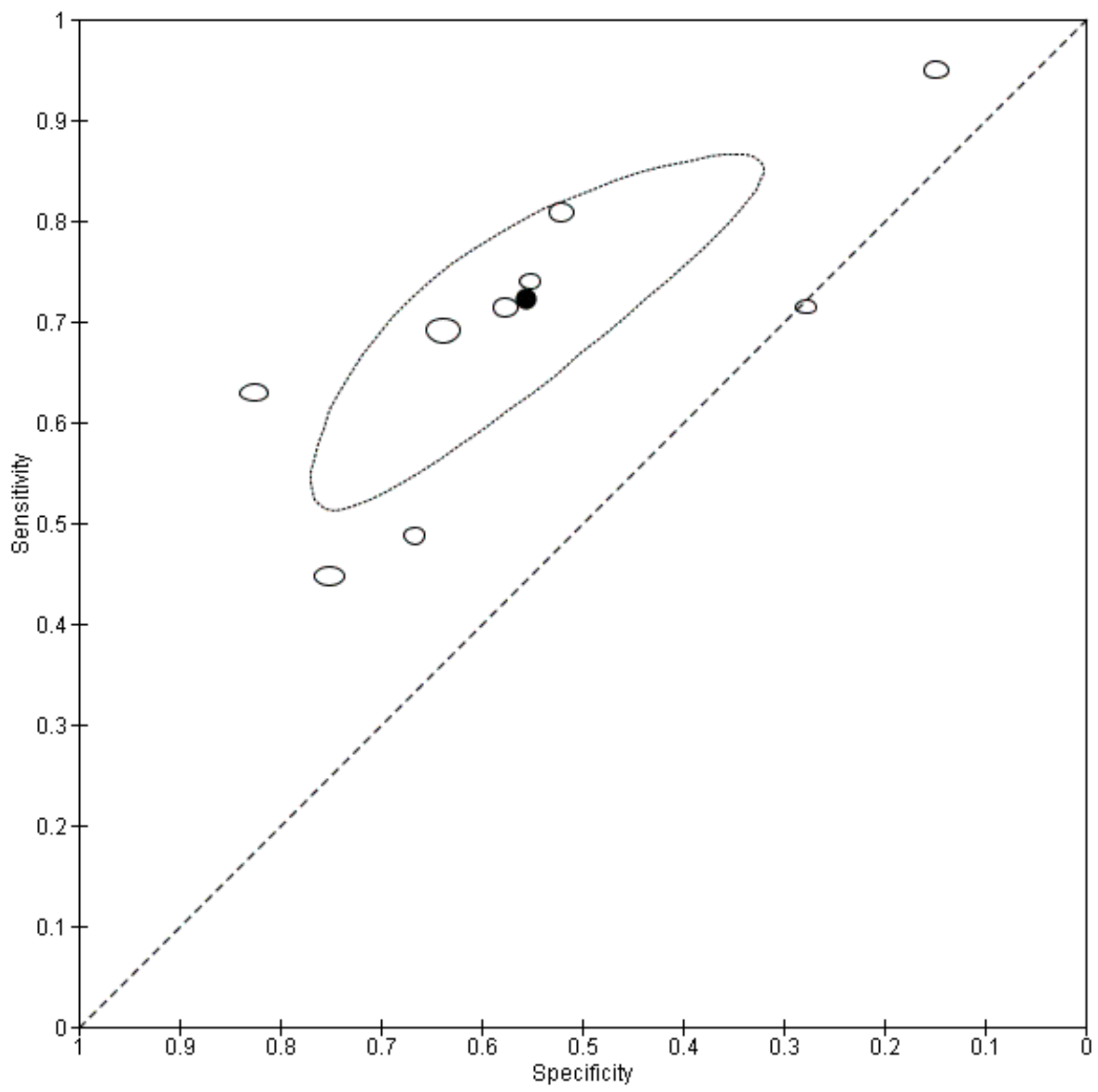

Four studies reported data regarding the accuracy of DMSA in predicting high-grade VUR according to renal units. The summary sensitivity and specificity estimates were $0.82(95 \% \mathrm{Cl} 0.67$ to
$0.91)$ and $0.55(95 \% \mathrm{Cl} 0.35$ to 0.74$)$, respectively (Figure 9). Metaregression and sensitivity analysis were limited due to the small number of studies. 
Figure 9. DMSA to detect renal units with high-grade VUR

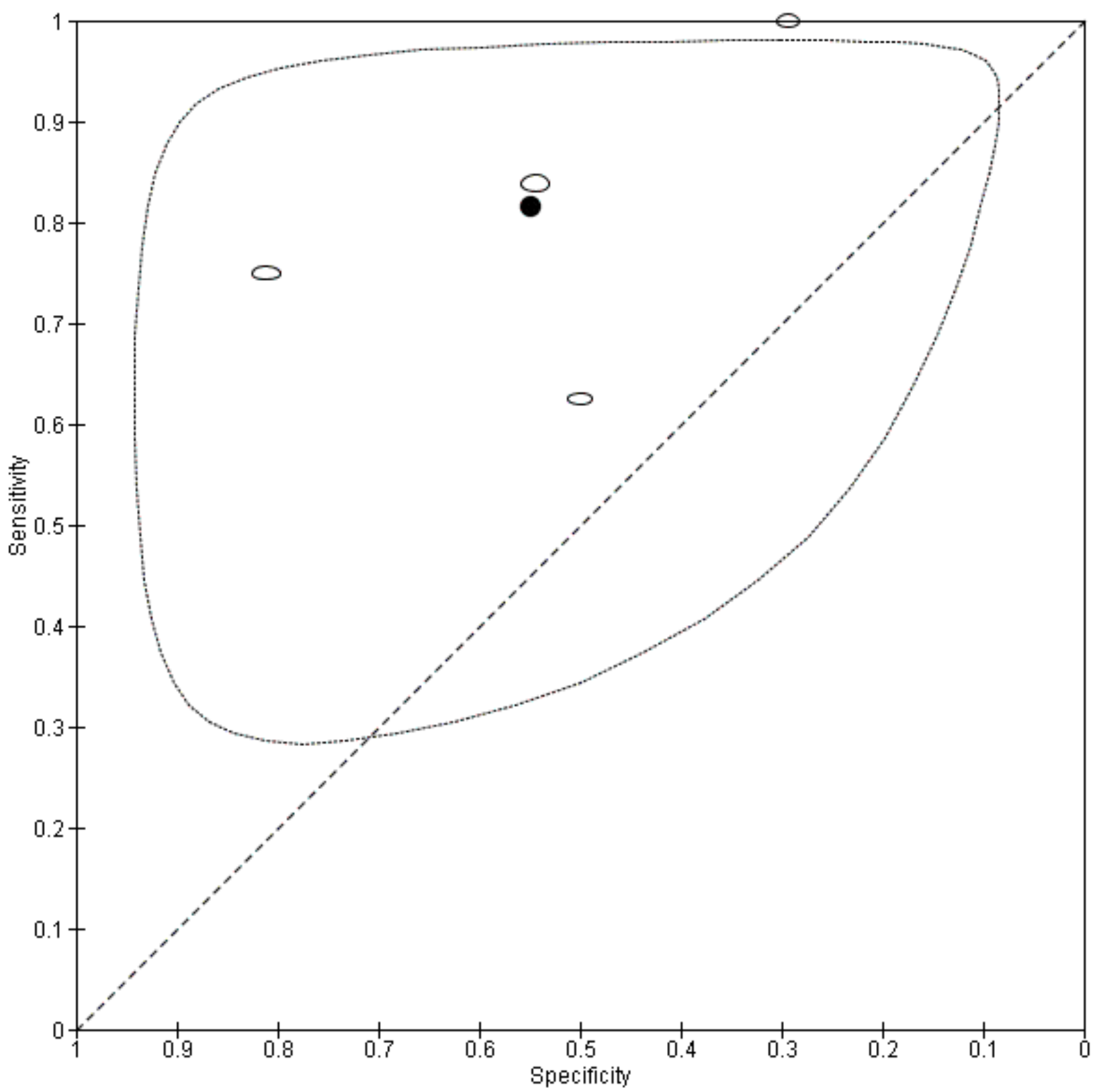

\section{Indirect comparison}

Based on the available data (19 studies for DMSA and 20 studies for ultrasound), there was strong evidence ( $P<0.001$ for both) that DMSA had a higher sensitivity and lower specificity than ultrasound for detecting VUR (Figure 10). Similarly, there was strong evidence $(\mathrm{P}<0.001$ for both) that DMSA had a higher sensitivity and lower specificity than ultrasound for detecting high-grade VUR (Figure $11)$. 
Figure 10. Ultrasound versus DMSA for the detection of VUR (indirect comparison)

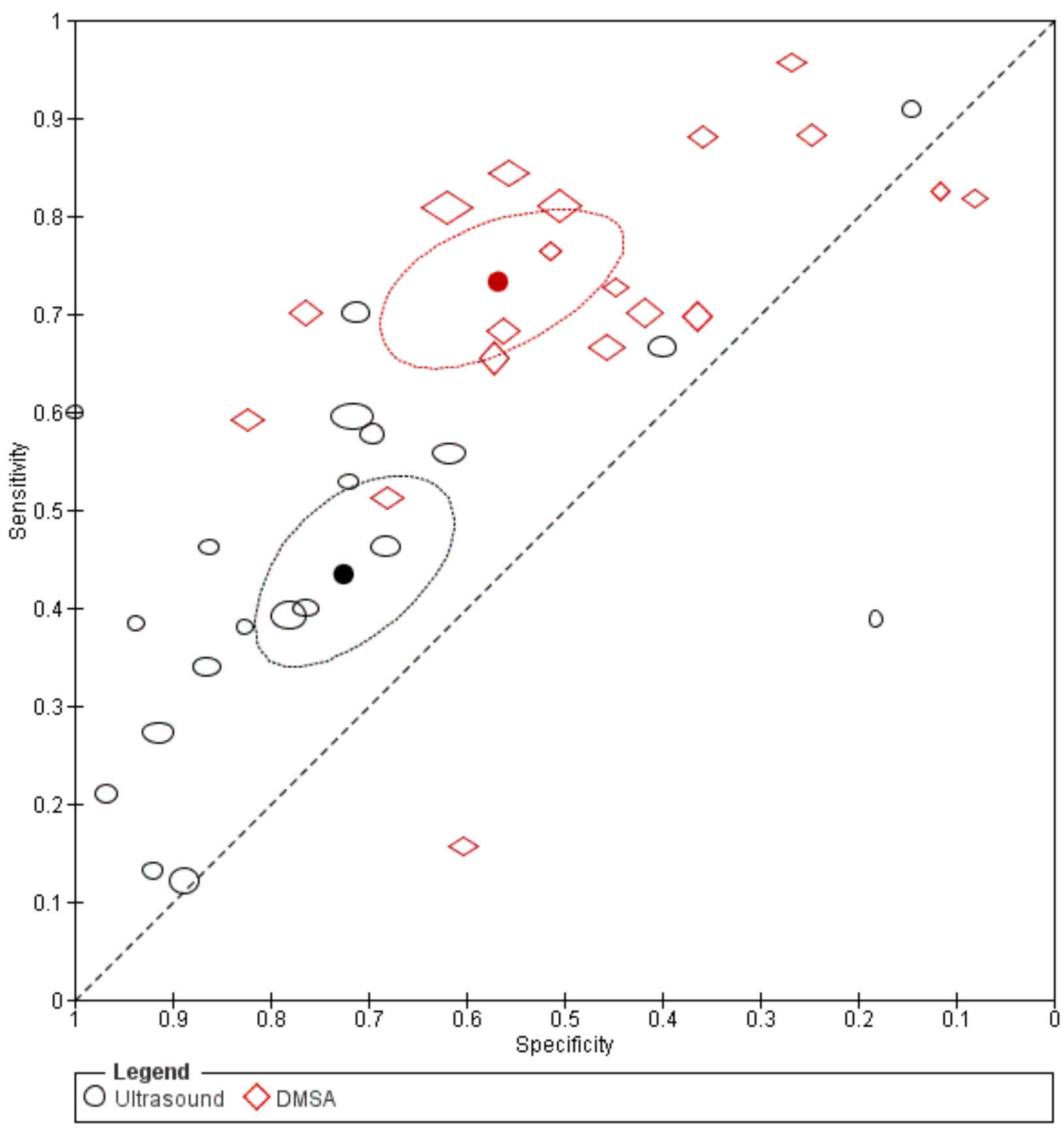


Figure 11. Ultrasound versus DMSA for the detection of High-Grade VUR (indirect comparison)

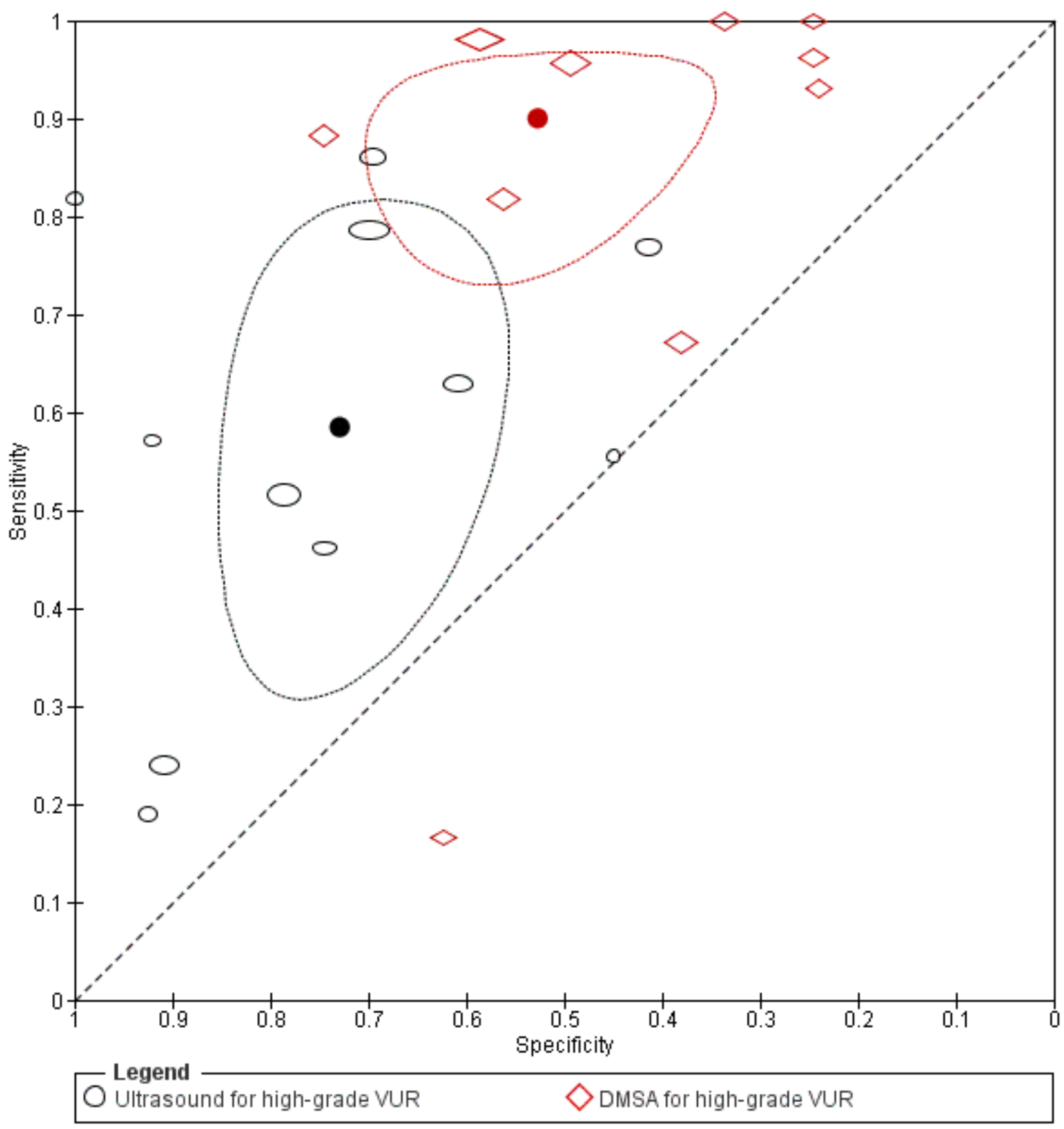

\section{Direct comparison}

Six studies provided data that allowed us to directly compare the DMSA and RBUS tests in detecting VUR (Figure 12). No clear pattern was visible (three studies showed that the DMSA was more sensitive and less specific, but three other studies showed other results). Quantitative direct comparison was not possible. 
Figure 12. Direct comparison of ultrasound and DMSA tests in detecting VUR

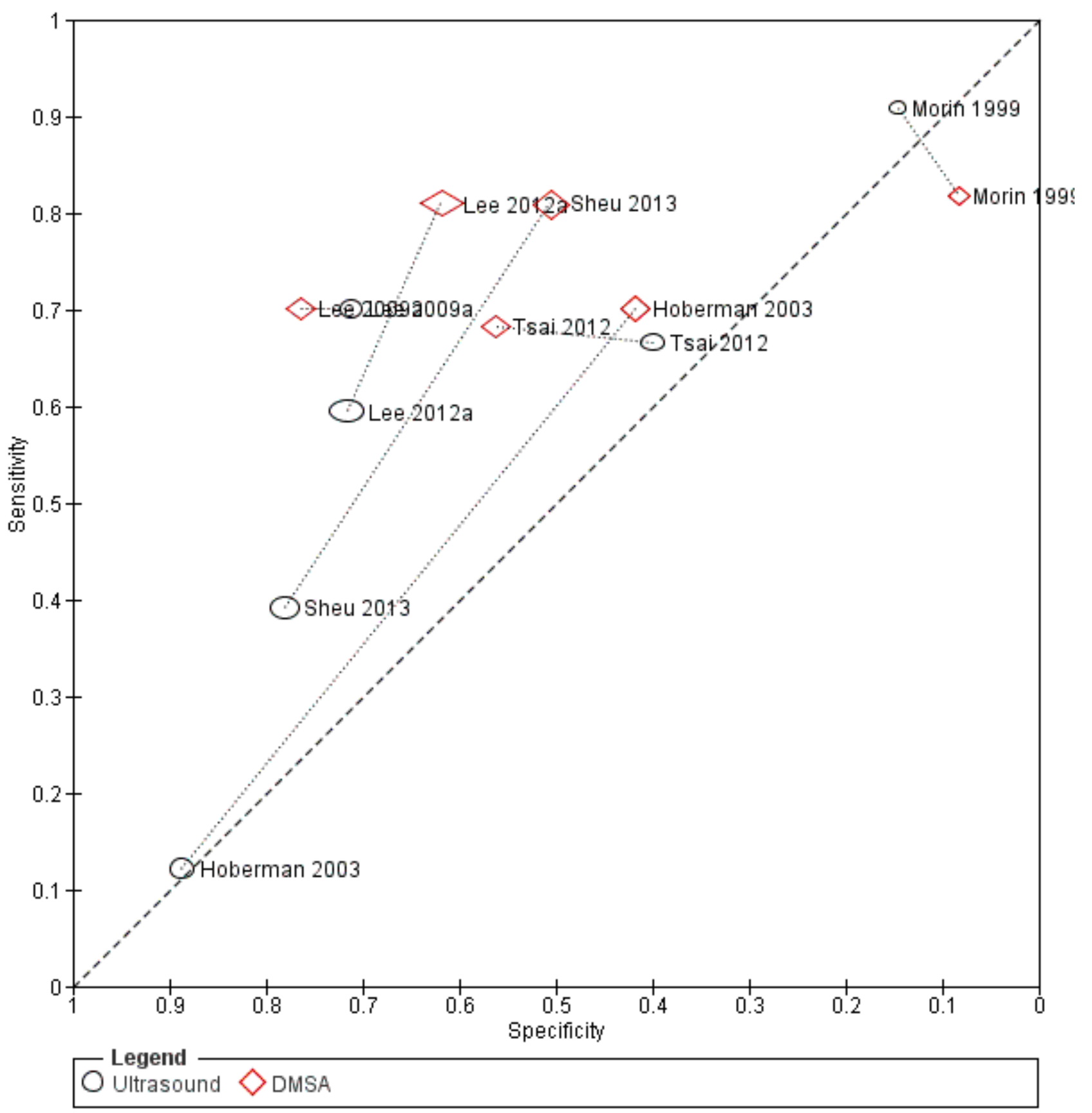

Six studies provided data that allowed us to directly compare the DMSA and RBUS tests in detecting high-grade VUR (Figure 13). Four studies showed that the DMSA was more sensitive and less specific than RBUS in detecting high-grade VUR. Quantitative direct comparison was not possible. 
Figure 13. Direct comparison of ultrasound and DMSA in detecting high-grade VUR

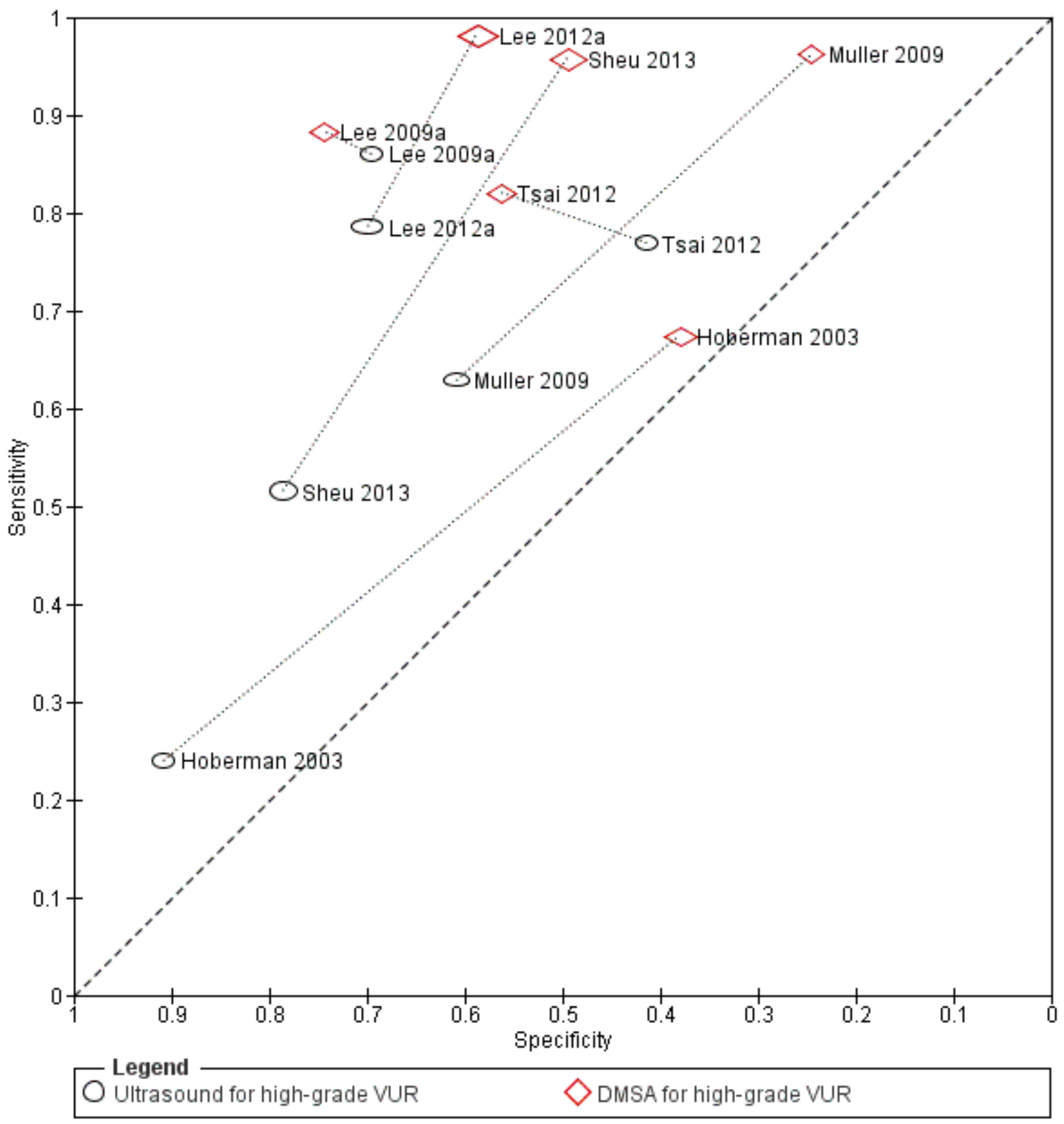

\section{Adverse events}

We did not find any information on the incidence of adverse events related to the performance of RBUS or DMSA.

\section{DISCUSSION}

\section{Summary of main results}

In this review, we examined the accuracy of ultrasound and DMSA tests in diagnosing VUR and high-grade VUR.
We found that the ultrasound tests lack the accuracy to detect either VUR or high-grade VUR (Summary of findings 1; Summary of findings 2), summary sensitivity values ranged from 0.44 to 0.59 and summary specificity values ranged from 0.78 to 0.79 ). Thus, the ultrasound test cannot replace the VCUG in detecting VUR. Nor can it serve to rule in or rule out VUR or high-grade VUR.

With regards to the DMSA test, examination of the scatter plots in ROC space reveals that despite the heterogeneity present, none of studies had accuracy values that were close to the top left hand corner of the ROC space. Thus, we can conclude that the DMSA 
cannot replace the VCUG in the detection of VUR or high-grade VUR. The data from articles that reported data in terms of renal units was generally consistent with this conclusion. In particular, we found that the DMSA lacks specificity to detect either VUR or high-grade VUR (Summary of findings 1; Summary of findings 2, summary specificity values ranged from 0.44 to 0.58 ). Therefore, it is not a useful test to rule in VUR or high-grade VUR. The sensitivity of the DMSA for detecting VUR was intermediate (Summary of findings 1 , summary sensitivity value of 0.75 ), which limits its usefulness in ruling out VUR. The probability of VUR in a child with a positive DMSA is only $49 \%$.

Because of its high sensitivity (Summary of findings 2, summary sensitivity of 0.93 ), a negative DMSA test appears, at first glance, to be useful for ruling out high-grade VUR. In an average risk population of children with UTIs, a child with a negative DMSA test has $a<1 \%$ probability of having high-grade VUR. However, the low specificity of the test cannot be ignored. In average risk population of children with febrile UTIs, the DMSA test will be positive in approximately $70 \%$ patients. Accordingly, most children with UTI may be inappropriately labelled as high risk and undergo additional testing. Other practical considerations also limit the usefulness of the DMSA as a screening test including: 1 ) it requires an additional trip to the hospital, 2) it necessitates placement of an intravenous line, 3) it may require sedation, 4) it incurs an additional cost, 5) it requires specialized equipment and personnel, which may not be available locally, 6) its results are not available at the time of UTI diagnosis, 7) differentiation of old scars from pyelonephritis may be difficult in children with previous UTIs or dysplasia, and 8) it exposes children to radiation. Thus, although the sensitivity of the acute-phase DMSA for high-grade VUR is high, we do not find any compelling evidence to recommend its routine use as a screening test for VUR or high-grade VUR.

\section{Strengths and weaknesses of the review}

Unexplained heterogeneity among studies was a limitation that reduced our confidence in the summary accuracy estimates. Nevertheless, examination of the scatter plots enabled us to reach firm conclusions regarding the utility of the tests in clinical practice.

\section{Applicability of findings to the review question}

We did not find any compelling evidence to recommend the routine use of RBUS or DMSA as a screening test for VUR or high-grade VUR.

\section{AUTHORS' CONCLUSIONS}

\section{Implications for practice}

Although the sensitivity of the acute-phase DMSA for the detection of high-grade VUR is high, we do not find any compelling evidence to recommend this test as a screening test for high-grade VUR because of the limitations discussed above.

\section{Implications for research}

Given the limitations of the RBUS and DMSA in detecting VUR, and given that the VCUG test itself is invasive, future studies should focus on the identification of biomarkers that could identify the small minority of children with UTI who need closer follow-up. Future studies should utilize representative populations, avoid the use of bag samples, and present results stratified by age. Since accuracy is best studied in populations suspected of having the target condition, studies should be limited to febrile children.

\section{ACKNOWLEDGEMENTS}

We wish to acknowledge the support of the Cochrane Collaboration's Diagnostic Test Accuracy editorial team and the peer referees for their assistance. 


\section{R E F E R E N C E S}

\section{References to studies included in this review}

Agras 2007 \{published data only\}

Agras K, Ortapamuk H, Naldoken S, Tuncel A, Atan A. Resolution of cortical lesions on serial renal scans in children with acute pyelonephritis. Pediatric Radiology 2007;37(2):153-8. [MEDLINE: 17171352]

\section{Alon 1986 \{published data only\}}

Alon U, Pery M, Davidai G, Berant M. Ultrasonography in the radiologic evaluation of children with urinary tract infection. Pediatrics 1986;78(1):58-64. [MEDLINE: 3523415]

\section{Alon 1999 \{published data only\}}

Alon US, Ganapathy S. Should renal ultrasonography be done routinely in children with first urinary tract infection?. Clinical Pediatrics 1999;38(1):21-5. [MEDLINE: 9924638]

\section{Ansari Gilani 2010 \{published data only\}}

Ansari Gilani K, Modaresi Esfeh J, Gholamrezanezhad A, Gholami A, Mamishi S, Eftekhari M, et al. Predictors of abnormal renal cortical scintigraphy in children with first urinary tract infection: the importance of time factor. International Urology \& Nephrology 2010;42(4):1041-7. [MEDLINE: 19798584]

\section{Ataei 2005 \{published data only\}}

Ataei N, Madani A, Habibi R, Khorasani M. Evaluation of acute pyelonephritis with DMSA scans in children presenting after the age of 5 years. Pediatric Nephrology 2005;20(10):1439-44. [MEDLINE: 16082551]

\section{Ataei 2008 \{published data only\}}

Ataei N, Safaian B, Madani A, Esfahani ST, Ataei F. The importance of $99 \mathrm{~m}$-Tc DMSA renal scintigraphy in evaluation of renal lesions in children with acute pyelonephritis. Acta Medica Iranica 2008; Vol. 46, issue 5:399-404. [EMBASE: 2008586412]

\section{Calisti 2005 \{published data only\}}

Calisti A, Perrotta ML, Oriolo L, Ingianna D, Sciortino R. Diagnostic workup of urinary tract infections within the first 24 months of life, in the era of prenatal diagnosis. The contribution of different imaging techniques to clinical management. Minerva Pediatrica 2005;57(5):269-73. [MEDLINE: 16205610]

\section{Camacho 2004 \{published data only\}}

Camacho V, Estorch M, Fraga G, Mena E, Fuertes J, Hernandez MA, et al. DMSA study performed during febrile urinary tract infection: a predictor of patient outcome? European Journal of Nuclear Medicine \& Molecular Imaging 2004;31(6):862-6. [MEDLINE: 14758509]

\section{Cascio 2002 \{published and unpublished data\}}

Cascio S, Chertin B, Yoneda A, Rolle U, Kelleher J, Puri P. Acute renal damage in infants after first urinary tract infection. Pediatric Nephrology 2002;17(7):503-5. [MEDLINE: 12172762]
Cleper 2004 \{published data only\}

Cleper R, Krause I, Eisenstein B, Davidovits M. Prevalence of vesicoureteral reflux in neonatal urinary tract infection. Clinical Pediatrics 2004;43(7):619-25. [MEDLINE: 15378148]

\section{Doganis 2007 \{published data only\}}

Doganis D, Siafas K, Mavrikou M, Issaris G, Martirosova A, Perperidis $\mathrm{G}$, et al. Does early treatment of urinary tract infection prevent renal damage?. Pediatrics 2007;120(4):e922-8. [MEDLINE: 17875650]

Donoso 2004 \{published and unpublished data\}

Donoso G, Lobo G, Arnello F, Arteaga MP, Hevia P, Rosati P, et al. Tc 99M DMSA scintigraphy in children with a first episode of acute pyelonephritis: correlation with laboratory tests, echography and the presence of vesico-ureteral reflux [Cintigrama renal DMSA en ninos con primera pielonefritis aguda: correlacion con examenes de laboratorio, ecografia y la presencia de reflujo vesico ureteral]. Revista Medica de Chile 2004;132(1):58-64. [MEDLINE: 15379054]

\section{El Shenoufy 2009 \{published data only\}}

El Shenoufy A, Issa M, Elfatah MA, Elabd N. Urine level of interleukin-8 as a non-invasive marker for diagnosis of vesicoureteral reflux in children. Journal of Medical Sciences 2009;9(3):133-9. [EMBASE: 2009396834]

Fernandez-Menendez 2003 \{published data only\}

Fernandez-Menendez JM, Malaga S, Matesanz JL, Solis G, Alonso S, Perez-Mendez C. Risk factors in the development of early technetium-99m dimercaptosuccinic acid renal scintigraphy lesions during first urinary tract infection in children. Acta Paediatrica 2003;92(1):21-6. [MEDLINE: 12650294]

Goldman 2000 \{published data only\}

Goldman M, Lahat E, Strauss S, Reisler G, Livne A, Gordin L, et al. Imaging after urinary tract infection in male neonates. Pediatrics 2000;105(6):1232-5. [MEDLINE: 10835062]

Hoberman 2003 \{published and unpublished data\} Hoberman A, Charron M, Hickey RW, Baskin M, Kearney DH, Wald ER. Imaging studies after a first febrile urinary tract infection in young children. New England Journal of Medicine 2003;348(3):195-202. [MEDLINE: 12529459]

\section{Ilyas 2002 \{published data only\}}

Ilyas M, Mastin ST, Richard GA. Age-related radiological imaging in children with acute pyelonephritis. Pediatric Nephrology 2002;17(1):30-4. [MEDLINE: 11793131]

\section{Ismaili 2011 \{published data only\}}

Ismaili K, Lolin K, Damry N, Alexander M, Lepage P, Hall M. Febrile urinary tract infections in 0 - to 3-month-old infants: a prospective follow-up study. Journal of Pediatrics 2011;158(1):91-4. [MEDLINE: 20708748]

* Ismaili K, Wissing KM, Lolin K, Le PQ, Christophe C, Lepage P, et al. Characteristics of first urinary tract infection with fever in children: a prospective clinical and imaging study. Pediatric 
Infectious Disease Journal 2011;30(5):371-4. [MEDLINE: 21502928]

\section{Jakobsson 1992 \{published data only\}}

Jakobsson B, Nolstedt L, Svensson L, Soderlundh S, Berg U. 99mTechnetium-dimercaptosuccinic acid scan in the diagnosis of acute pyelonephritis in children: relation to clinical and radiological findings. Pediatric Nephrology 1992;6(4):328-34. [MEDLINE: 1343562]

* Jakobsson B, Soderlundh S, Berg U. Diagnostic significance of 99mTc-dimercaptosuccinic acid (DMSA) scintigraphy in urinary tract infection. Archives of Disease in Childhood 1992;67(11):1338-42. [MEDLINE: 1335226]

\section{Kim 2006 \{published data only\}}

Kim GY, Lee SW, Moon HS, Park HY, Choi HY. The efficacy of imaging studies after a first febrile urinary tract infection in young children with normal prenatal ultrasonographic findings. Korean Journal of Urology 2006;47(3):293-7. [EMBASE: 2006267204]

\section{Lavocat 1997 \{published data only\}}

Lavocat MP, Granjon D, Allard D, Gay C, Freycon MT, Dubois F. Imaging of pyelonephritis. Pediatric Radiology 1997;27(2):159-65. [MEDLINE: 9028852]

\section{Lee 2009a \{published data only\}}

Lee HY, Soh BH, Hong CH, Kim MJ, Han SW. The efficacy of ultrasound and dimercaptosuccinic acid scan in predicting vesicoureteral reflux in children below the age of 2 years with their first febrile urinary tract infection. Pediatric Nephrology 2009;24(10):2009-13. [MEDLINE: 19593590]

\section{Lee 2012a \{published data only\}}

Lee JH, Kim MK, Park SE. Is a routine voiding cystourethrogram necessary in children after the first febrile urinary tract infection?. Acta Paediatrica 2012;101(3):e105-9. [MEDLINE: 22040289]

\section{Lin 2007 \{published data only\}}

Lin CH, Yang LY, Wamg HH, Chang JW, Shen MC, Tang RB. Evaluation of imaging studies for vesicoureteral reflux in infants with first urinary tract infection. Acta Paediatrica Taiwanica 2007;48(2):68-72. [MEDLINE: 17626605]

\section{Lopez Sastre 2007 \{published data only\}}

Lopez Sastre JB, Ramos Aparicio A, Coto Cotallo GD, Fernandez Colomer B, Crespo Hernandez M, Grupo de Hospitales Castrillo. Urinary tract infection in the newborn: clinical and radio imaging studies. Pediatric Nephrology 2007;22(10):1735-41. [MEDLINE: 17665222]

\section{Mahant 2002 \{published data only\}}

Mahant S, Friedman J, MacArthur C. Renal ultrasound findings and vesicoureteral reflux in children hospitalised with urinary tract infection. Archives of Disease in Childhood 2002;86(6):419-20. [MEDLINE: 12023172]
Melis 1992 \{published data only\}

Melis K, Vandevivere J, Hoskens C, Vervaet A, Sand A, Van Acker KJ. Involvement of the renal parenchyma in acute urinary tract infection: the contribution of $99 \mathrm{mTc}$ dimercaptosuccinic acid scan. European Journal of Pediatrics 1992; Vol. 151, issue 7:536-9. [MEDLINE: 1327798]

\section{Montini 2009 \{published data only\}}

Montini G, Rigon L, Zucchetta P, Fregonese F, Toffolo A, Gobber D, et al. Prophylaxis after first febrile urinary tract infection in children? A multicenter, randomized, controlled, noninferiority trial. Pediatrics 2008;122(5):1064-71. [MEDLINE: 18977988]

\section{Morin 1999 \{published data only\}}

Morin D, Veyrac C, Kotzki PO, Lopez C, Dalla Vale F, Durand MF, et al. Comparison of ultrasound and dimercaptosuccinic acid scintigraphy changes in acute pyelonephritis. Pediatric Nephrology 1999;13(3):219-22. [MEDLINE: 10353409]

\section{Muller 2009 \{published data only\}}

Muller L, Preda I, Jacobsson B, Sixt R, Jodal U, Hansson S, Hellstrom M. Ultrasonography as predictor of permanent renal damage in infants with urinary tract infection. Acta Paediatrica 2009;98(7):1156-61. [MEDLINE: 19397555]

Preda I, Jodal U, Sixt R, Stokland E, Hansson S. Imaging strategy for infants with urinary tract infection: a new algorithm. Journal of Urology 2011;185(6):1046-52. [MEDLINE: 21247606]

* Preda I, Jodal U, Sixt R, Stokland E, Hansson S. Value of ultrasound in evaluation of infants with first urinary tract infection. Journal of Urology 2010;183(5):1984-8. [MEDLINE: 20303537]

\section{Oh 2012 \{published data only\}}

Oh MM, Cheon J, Kang SH, Park HS, Lee JG, Moon du G. Predictive factors for acute renal cortical scintigraphic lesion and ultimate scar formation in children with first febrile urinary tract infection. Journal of Urology 2010; Vol. 183, issue 3:1146-50. [MEDLINE: 20096887]

Oh MM, Jin MH, Bae JH, Park HS, Lee JG, Moon du G. The role of vesicoureteral reflux in acute renal cortical scintigraphic lesion and ultimate scar formation. Journal of Urology 2008; Vol. 180, issue 5:2167-70. [MEDLINE: 18804801]

* Oh MM, Kim JW, Park MG, Kim JJ, Yoo KH, Moon DG. The impact of therapeutic delay time on acute scintigraphic lesion and ultimate scar formation in children with first febrile UTI. European Journal of Pediatrics 2012;171(3):565-70. [MEDLINE: 22048628]

\section{Preda 2007 \{published data only\}}

Preda I, Jodal U, Sixt R, Stokland E, Hansson S. Normal dimercaptosuccinic acid scintigraphy makes voiding cystourethrography unnecessary after urinary tract infection. Journal of Pediatrics 2007;151(6):581-4, 584.e1. [MEDLINE: 18035134] 
Sayedzadeh 2011 \{published data only\}

Sayedzadeh SA, Malaki M, Shoaran M, Nemati M. Kidney imaging in management of delayed febrile urinary tract infection. Saudi Journal of Kidney Diseases \& Transplantation 2011;22(6):1160-3. [MEDLINE: 22089774]

\section{Sheu 2013 \{published data only\}}

Sheu JN, Wu KH, Chen SM, Tsai JD, Chao YH, Lue KH. Acute 99mTc DMSA scan predicts dilating vesicoureteral reflux in young children with a first febrile urinary tract infection: a population-based cohort study. Clinical Nuclear Medicine 2013;38(3):163-8. [MEDLINE: 23354031]

\section{Sorkhi 2011 \{published data only\}}

Sorkhi H. Prediction of vesicoureteral reflux in children with first urinary tract infection by DMSA and ultrasonography [abstract]. Iranian Journal of Kidney Diseases 2011; Vol. 5:48-9. [EMBASE: 70673889]

\section{Soylu 2007 \{published data only\}}

Soylu A, Kasap B, Demir K, Turkmen M, Kavukcu S. Predictive value of clinical and laboratory variables for vesicoureteral reflux in children. Pediatric Nephrology 2007;22(6):844-8. [MEDLINE: 17273861]

\section{Supavekin 2013a \{published data only\}}

Supavekin S, Surapaitoolkorn W, Pravisithikul N, Kutanavanishapong S, Chiewvit S. The role of DMSA renal scintigraphy in the first episode of urinary tract infection in childhood. Annals of Nuclear Medicine 2013;27(2):170-6. [MEDLINE: 23203209]

\section{Tsai 1996 \{published data only\}}

Tsai TC, Huang FY, Yang CT, Shih BF. Dimercaptosuccinic acid renal scan in children with urinary tract infection. Chung-Hua Min Kuo Hsiao Erh Ko i Hsueh Hui Tsa Chih 1996; Vol. 37, issue 2:111-4. [MEDLINE: 8935409]

\section{Tsai 2012 \{published data only\}}

Tsai JD, Huang CT, Lin PY, Chang JH, Lee MD, Huang, FY, et al. Screening high-grade vesicoureteral reflux in young infants with a febrile urinary tract infection. Pediatric Nephrology 2012;27(6):955-63. [MEDLINE: 22374404]

\section{Tseng 2007 \{published data only\}}

Tseng MH, Lin WJ, Lo WT, Wang SR, Chu ML, Wang CC. Does a normal DMSA obviate the performance of voiding cystourethrography in evaluation of young children after their first urinary tract infection?. Journal of Pediatrics 2007;150(1):96-9. [MEDLINE: 17188624]

\section{Zaki 1996 \{published data only\}}

Zaki M, Al-Mutari G, Al-Saleh Q, Ramadan DG. Febrile urinary tract infection in children: role of $99 \mathrm{mTc}$-dimercaptosuccinic acid (DMSA) scan and other imaging techniques. Annals of Saudi Medicine 1996;16(4):410-3. [MEDLINE: 17372481]

\section{Zaki 2003 \{published data only\}}

Zaki M, Mutari GA, Badawi M, Ramadan D, Al deen Hanafy E. Vesicoureteric reflux in Kuwaiti children with first febrile urinary tract infection. Pediatric Nephrology 2003;18(9):898-901. [MEDLINE: 12883980]

\section{References to studies excluded from this review}

Adibi 2013 \{published data only\}

Adibi A, Gheysari A, Azhir A, Merikhi A, Khami S, Tayari N. Value of sonography in the diagnosis of mild, moderate and severe vesicoureteral reflux in children. Saudi Journal of Kidney Diseases \& Transplantation 2013;24(2):297-302. [MEDLINE: 23538353]

\section{Ahmadzadeh 2007 \{published data only\}}

Ahmadzadeh A, Askarpour S. Association of urinary tract abnormalities in children with first urinary tract infection. Pakistan Journal of Medical Sciences 2007;23(1):88-91. [EMBASE: 2007133746]

Ajdinovic 2005 \{published data only\}

Ajdinovic B, Krstic Z, Dopuda M, Jaukovic L. Renal scintigraphy in children with urinary tract infections. Vojnosanitetski Pregled 2005;62(10):745-9. [MEDLINE: 16305102]

Ajdinovic 2006 \{published data only\}

Ajdinovic B, Jaukovic L, Krstic Z, Dopuda M. Technetium-99mdimercaptosuccinic acid renal scintigraphy in children with urinary tract infections. Hellenic Journal of Nuclear Medicine 2006; Vol. 9, issue 1:27-30. [MEDLINE: 16617390]

Ajdinovic 2008 \{published data only\}

Ajdinovic B, Jaukovic L, Krstic Z, Dopuda M. Impact of micturating cystourethrography and DMSA renal scintigraphy on the investigation scheme in children with urinary tract infection. Annals of Nuclear Medicine 2008;22(8):661-5. [MEDLINE: 18982468]

Ajdinovic 2010 \{published data only\}

Ajdinovic B, Jaukovic L, Krstic Z, Dopudja M. Comparison of DMSA renal scintigraphy and micturating cystourethrography in children with urinary tract infection [abstract]. Pediatric Research 2010;68:490. [DOI: 10.1203/00006450-201011001-00984]

\section{Aktas 2008 \{published data only\}}

Aktas GE, Inanir S, Turoglu HT. Renal cortical involvement in children with first UTI: does it differ in the presence of primary VUR?. Annals of Nuclear Medicine 2008;22(10):877-81. [MEDLINE: 19142706]

\section{Almeida 1994 \{published data only\}}

Almeida HN, Ribeiro M, Colarinha J, Santos JF, Rosa FC. Imaging methods in the study of urinary tract infections in children. Acta Medica Portuguesa 1994;7 Suppl 1:S15-20. [MEDLINE: 7653274]

Alshamsam 2009 \{published data only\}

Alshamsam L, Al Harbi A, Fakeeh K, Al Banyan E. The value of renal ultrasound in children with a first episode of urinary tract infection. Annals of Saudi Medicine 2009;29(1):46-9. [MEDLINE: 19139618] 
Alvarez 2009 \{published data only\}

Alvarez MD, Batista BA, Cordova RP, Arias MI, Marrero BD. Prevalence and characteristics of the vesicoureteral reflux in infants who suffered neonatal urinary tract infection [Prevalencia y caracteristicas del reflujo vesicoureteral en ninos que presentaron infeccion urinaria neonatal]. Archivos Argentinos de Pediatria 2009; Vol. 107, issue 4:329-34. [MEDLINE: 19753440]

\section{Alzen 1994 \{published data only\}}

Alzen G, Wildberger JE, Muller-Leisse C, Deutz FJ. Ultrasound screening of vesico-uretero-renal reflux [Sonographisches screening des vesico-uretero-renalen refluxes]. Klinische Padiatrie 1994;206(3):178-80. [MEDLINE: 8051912]

\section{Asanuma 2012 \{published data only\}}

Asanuma H, Satoh H, Matsui Z, Mizuno R, Masuda A, Kono H, et al. Color doppler sonographic evaluation of ureteric jet angle in detecting high grade vesicoureteral reflux in children [abstract]. Journal of Urology 2012;4 Suppl 1:e248. [EMBASE: 70720306]

\section{Balbay 1998 \{published data only\}}

Balbay MD, Ozsan O, Ozbek E, Ozkan S, Gunes A. Comparison of screening of vesicoureteral reflux with renal ultrasound and voiding cystourethrography. International Urology \& Nephrology 1998;30(3):263-6. [MEDLINE: 9696330]

\section{Barros 2010 \{published data only\}}

Barros AC, Oliveira E, Rodrigues LR, Carneiro F, Alves V, Cruz ME. Urinary tract infection in children: 5 years of clinical and microbiological data [Infeccoes urinarias na crianca: 5 anos de dados clinicos e microbiologicos]. Arquivos de Medicina 2010;24(6):247-252. [EMBASE: 2012116611]

\section{Beiraghdar 2012 \{published data only\}}

Beiraghdar F, Panahi Y, Einollahi B, Moharamzad Y, Nemati E, Amirsalari S. Predisposing factors for renal scarring in children with urinary tract infection. Saudi Journal of Kidney Diseases \& Transplantation 2012;23(3):532-7. [MEDLINE: 22569440]

\section{Benador 1994 \{published data only\}}

Benador D, Benador N, Slosman DO, Nussle D, Mermillod B, Girardin E. Cortical scintigraphy in the evaluation of renal parenchymal changes in children with pyelonephritis. Journal of Pediatrics 1994;124(1):17-20. [MEDLINE: 8283371]

\section{Benador 1997 \{published data only\}}

Benador D, Benador N, Slosman D, Mermillod B, Girardin E. Are younger children at highest risk of renal sequelae after pyelonephritis?. Lancet 1997;349(9044):17-9. [MEDLINE: 8988117]

\section{Benador 1998 \{published data only\}}

Benador N, Siegrist CA, Gendrel D, Greder C, Benador D, Assicot M, et al. Procalcitonin is a marker of severity of renal lesions in pyelonephritis. Pediatrics 1998;102(6):1422-5. [MEDLINE: 9832579]

\section{Benador 2001 \{published data only\}}

Benador D, Neuhaus TJ, Papazyan JP, Willi UV, Engel-Bicik I, Nadal D, et al. Randomised controlled trial of three day versus
10 day intravenous antibiotics in acute pyelonephritis: effect on renal scarring. Archives of Disease in Childhood 2001;84(3):241-6. [MEDLINE: 11207174]

Ben-Ami 1989 \{published data only\}

Ben-Ami T, Rozin M, Hertz M. Imaging of children with urinary tract infection: a tailored approach. Clinical Radiology 1989;40(1):64-7. [MEDLINE: 2646060]

\section{Bergius 1990 \{published data only\}}

Bergius AR, Niskanen K, Kekomaki M. Detection of significant vesico-ureteric reflux by ultrasound in infants and children. Zeitschrift fur Kinderchirurgie 1990;45(3):144-5. [MEDLINE: 2197833]

\section{Berry 2012 \{published data only\}}

Berry CS, Vander BB, Koff SA, Alpert SA, Jayanthi VR. Is VCUG still indicated following the first episode of urinary tract infection in boys?. Urology 2012;80(6):1351-5. [MEDLINE: 23206783]

\section{Bhatnagar 2002 \{published data only\}}

Bhatnagar V, Mitra DK, Agarwala S, Kumar R, Patel C, Malhotra AK, et al. The role of DMSA scans in evaluation of the correlation between urinary tract infection, vesicoureteric reflux, and renal scarring. Pediatric Surgery International 2002;18(2-3):128-34. [MEDLINE: 11956778]

\section{Biggi 2001 \{published data only\}}

Biggi A, Dardanelli L, Cussino P, Pomero G, Noello C, Sernia O, et al. Prognostic value of the acute DMSA scan in children with first urinary tract infection. Pediatric Nephrology 2001; Vol. 16, issue 10:800-4. [MEDLINE: 11605786]

\section{Biyikli 2004 \{published data only\}}

Biyikli NK, Alpay H, Ozek E, Akman I, Bilgen H. Neonatal urinary tract infections: analysis of the patients and recurrences. Pediatrics International 2004;46(1):21-5. [MEDLINE: 15043659]

\section{Blane 1993 \{published data only\}}

Blane CE, DiPietro MA, Zerin JM, Sedman AB, Bloom DA. Renal sonography is not a reliable screening examination for vesicoureteral reflux. Journal of Urology 1993;150(2 Pt 2):752-5. [MEDLINE: 8326640]

\section{Boudailliez 1989 \{published data only\}}

Boudailliez B, McMahon Y, Grumbach Y, Baratte B, Caraco MH, Piussan $C$. Role of ultrasound in studying the first urinary infection in children [Place de l'echographie dans l'investigation d'une premiere infection urinaire chez l'enfant]. Archives Francaises de Pediatrie 1989;46(2):113-5. [MEDLINE: 2660762]

\section{Bouissou 1988 \{published data only\}}

Bouissou F, Danet B, Meguira B, Martinez S, Guiraud R, Barthe P. Quantitative renal scintigraphy with technetiumlabelled dimercaptosuccinic acid in children. Presse Medicale 1988;17(16):791-4. [MEDLINE: 2838835]

\section{Bouissou 1994 \{published data only\}}

Bouissou F, Belmonte D, Danet B, Baunin C, Raynaud N, Salles JP, et al. Value of DMSA renal scintigraphy in acute 
pyelonephritis in pediatric patients [Interet de la scintigraphie renale au dmsa dans les pyelonephritis aigues de l'enfant]. Annales de Pediatrie 1994;41(1):7-13. [EMBASE: 1994068022]

Butorac-Ahel 2011 \{published data only\}

Butorac-Ahel I, Flajsman-Raspot S, Subat-Dezulovic M. Applicability of more selective imaging program in children diagnosed with a first urinary tract infection [abstract]. Pediatric Nephrology 2011;26(9):1697-8. [EMBASE: 70530853]

\section{Cabezuelo Huerta 2005 \{published data only\}}

Cabezuelo Huerta G, Vidal Mico S, Frontera Izquierdo P. Urinary tract infection in children under two years of age in out-patient setting and detection of vesicoureteral reflux [Infeccion del tracto urinario en menores de dos anos de edad en el medio ambulatorio y la deteccion de reflujo vesico ureteral]. Revista Espanola de Pediatria 2005;61(2):106-9. [EMBASE: 2005220536]

\section{Caillaud 2013 \{published data only\}}

Caillaud C, Abely M, Pons A, Brunel D, Viprey M, Pietrement C. A retrospective study to evaluate a protocol aimed at reducing the number of unnecessary voiding cystourethrographies performed after a first episode of febrile urinary tract infection [Evaluation d'un protocole de limitation des indications de cystographie dans les infections urinaires febriles]. Archives de Pediatrie 2013;20(5):476-83. [MEDLINE: 23562318]

\section{Calleja Gero 2008 \{published data only\}}

Calleja Gero L, Cabeza Martin B, Garcia Garcia MC, Rabadan Sanz B, Sanchez Bayle MA, Cano Fernandez J. Non-E. coli urinary infections and urinary tract anomalies [Infecciones de orina por germenes no E. coli y alteraciones nefrourologicas]. Revista Espanola de Pediatria 2008;64(6):438-40. [EMBASE: 2009034303]

\section{Castello Girona 1995 \{published data only\}}

Castello Girona F, Vilaplana Canto E, Yeste Fernandez D, Roca Bielsa I, Enriquez Civico G. 99mTc dimercaptosuccinic scan in the study of the first urinary tract infection in infants [Gammagrafia con 99mtecnecio-acido dimercaptosuccinico en el estudio de la primera infeccion urinaria del lactante]. Anales Espanoles de Pediatria 1995;42(2):118-22. [EMBASE: 1995091284]

\section{Cemerlic-Zecevic 2002 \{published data only\}}

Cemerlic-Zecevic E, Milicic-Pokrajac D, Dzinovic A. Urinary tract infections and vesicoureteral reflux as a cause of renal parenchymal damage [Infekcija urinarnog trakta i vezikoureteralni refluks kao uzrok renalnog parenhimnog ostecenja]. Medicinski Arhiv 2002;56(3 Suppl 1):14-6. [MEDLINE: 12762236]

\section{Cheng 2011 \{published data only\}}

Cheng CH, Hang JF, Tsau YK, Lin TY. Nephromegaly is a significant risk factor for renal scarring in children with first febrile urinary tract infections. Journal of Urology 2011;186(6):2353-7. [MEDLINE: 22019042]

\section{Chroustova 2006 \{published data only\}}

Chroustova D, Palyzova D, Urbanova I, Kolska M. Results of a five-year study of 99mTc DMSA renal scintigraphy in children and adolescents following acute pyelonephritis. Nuclear Medicine Review 2006;9(1):46-50. [MEDLINE: 16791804]

Clarke 1996 \{published data only\}

Clarke SE, Smellie JM, Prescod N, Gurney S, West DJ.

Technetium-99m-DMSA studies in pediatric urinary infection. Journal of Nuclear Medicine 1996; Vol. 37, issue 5:823-8. [MEDLINE: 8965153]

\section{Cortes 2010 \{published data only\}}

Cortes D, Lytzen R, Thorup J. Copenhagen experience with the nice-guidelines for children with upper urinary tract infection [abstract]. Pediatric Nephrology 2010;25(9):1849. [EMBASE: 70438372]

\section{Craig 1998 \{published data only\}}

Craig JC, Irwig LM, Knight JF, Sureshkumar P, Roy LP. Symptomatic urinary tract infection in preschool Australian children. Journal of Paediatrics \& Child Health 1998;34(2):154-9. [MEDLINE: 9588640]

\section{D'Souza 2013 \{published data only\}}

D'Souza MK, Verma NS, Prasanna Kumar AR, Das K, Phadke KD, Iyengar A. Detecting reflux: does ureteric jet Doppler waveform have a role?. Pediatric Nephrology 2013;28(9):1821-6. [MEDLINE: 23588743]

\section{David 1998 \{published data only\}}

David C, Dacher JN, Monroc M, Eurin D, Le Dosseur P. Voiding cysto-urethrography after a first episode of acute pyelonephritis in girls [Cystographie retrograde apres un premier episode de pyelonephrite aigue chez la fillette et l'adolescente]. Journal de Radiologie 1998;79(2):133-7. [EMBASE: 1998136587]

\section{De Mutiis 2011 \{published data only\}}

De Mutiis C, La Scola C, Mencarelli F, Marsciani M, Lega MV, Pasini A, et al. Febrile urinary tract infection: what investigative protocol? [abstract]. Pediatric Nephrology 2011;26(9):1714. [EMBASE: 70530904]

\section{DiPietro 1997 \{published data only\}}

DiPietro MA, Blane CE, Zerin JM. Vesicoureteral reflux in older children: concordance of US and voiding cystourethrographic findings. Radiology 1997;205(3):821-2. [MEDLINE: 9393542]

\section{Ditchfield 1994 \{published data only\}}

Ditchfield MR, De Campo JF, Cook DJ, Nolan TM, Powell HR, Sloane R, et al. Vesicoureteral reflux: an accurate predictor of acute pyelonephritis in childhood urinary tract infection?. Radiology 1994;190(2):413-5. [MEDLINE: 8284391]

Ditchfield MR, de Campo JF, Nolan TM, Cook DJ, Grimwood K, Powell HR, et al. Risk factors in the development of early renal cortical defects in children with urinary tract infection. AJR. American Journal of Roentgenology 1994;162(6):1393-7. [MEDLINE: 8192006]

\section{Ditchfield 1998 \{published data only\}}

Ditchfield MR, Nadel HR. The DMSA scan in paediatric urinary tract infection. Australasian Radiology 1998;42(4):318-20. [MEDLINE: 9833368] 


\section{Donoso 2012 \{published data only\}}

Donoso G, Lagos E, Rosati P, Hevia P, Cuevas K, Lobo G, et al. Evolution of scintigraphic renal lesions in children after an episode of acute pyelonephritis [Una lesion en el cintigrama renal DMSA 6 meses post fase aguda de una pielonefritis representa siempre una cicatriz: un debate abierto]. Revista Medica de Chile 2012;140(6):746-50. [MEDLINE: 23282612]

\section{Dura Trave 1997 \{published data only\}}

Dura Trave T, Gonzalez Montero R, Juste Ruiz M, Gonzalez de Dios J, Carratala Marco F, Moya Benavent M, et al. Usefulness of renal scintigraphy in the assessment of the first febrile urinary infection in children [Utilidad de la gammagrafia renal en la valoracion de la primera infeccion urinaria febril en la edad pediatrica]. Anales Espanoles de Pediatria 1997;47(4):378-82. [MEDLINE: 9499305]

\section{Ekim 1992 \{published data only\}}

Ekim M, Tumer N, Salih M, Yalcinkaya F, Ensari C, Cakar N. Color Doppler ultrasonography in the diagnosis of vesicoureteric reflux in children [abstract]. Pediatric Nephrology 1992;6:C120.

\section{Elison 1992 \{published data only\}}

Elison BS, Taylor D, Van der Wall H, Pereira JK, Cahill S, Rosenberg AR, et al. Comparison of DMSA scintigraphy with intravenous urography for the detection of renal scarring and its correlation with vesicoureteric reflux. British Journal of Urology 1992;69(3):294-302. [MEDLINE: 1314684]

\section{El-Naggari 2011 \{published data only\}}

El-Naggari M, Elnour I. Is a British nice radiological guideline concerning children with urinary tract infection suitable for Oman and the developing countries? [abstract]. Pediatric Nephrology 2011;26(9):1713. [EMBASE: 70530901]

\section{Fallahzadeh 2008 \{published data only\}}

Fallahzadeh MK, Fallahzadeh MH, Ghane F. Reliability of ultrasonography in prediction of vesicoureteral reflux in children. Iranian Red Crescent Medical Journal 2008; Vol. 10, issue 2:131-2. [EMBASE: 2008429932]

\section{Farnsworth 1991 \{published data only\}}

Farnsworth RH, Rossleigh MA, Leighton DM, Bass SJ, Rosenberg AR. The detection of reflux nephropathy in infants by 99 mtechnetium dimercaptosuccinic acid studies. Journal of Urology 1991;145(3):542-6. [MEDLINE: 1847727]

Fidan 2013 \{published data only\}

Fidan C, Kantar A, Gulleroglu K, Ozcan KE, Uslu N, Bayrakci U, et al. Efficacies of screening methods in the diagnosis of urinary tract infection. Pediatric Nephrology 2013;28(8):1387-8. [EMBASE: 71127052]

\section{Foresman 2001 \{published data only\}}

Foresman WH, Hulbert WC Jr, Rabinowitz R. Does urinary tract ultrasonography at hospitalization for acute pyelonephritis predict vesicoureteral reflux?. Journal of Urology 2001;165(6 Pt 2):2232-4. [MEDLINE: 11371951]

\section{Fouzas 2010 \{published data only\}}

Fouzas S, Krikelli E, Vassilakos P, Gkentzi D, Papanastasiou DA, Salakos C. DMSA scan for revealing vesicoureteral reflux in young children with urinary tract infection. Pediatrics 2010;126(3):e513-9. [MEDLINE: 20679300]

Gelfand 2000 \{published data only\} Gelfand MJ, Barr LL, Abunku O. The initial renal ultrasound examination in children with urinary tract infection: the prevalence of dilated uropathy has decreased. Pediatric Radiology 2000;30(10):665-70. [MEDLINE: 11075596]

Geronikola-Trapali 2010 \{published data only\} Geronikola-Trapali X, Armeniakos I, Karampina P, Stafanoyiannis A, Lyra V, Bakalis S, et al. The art of timing for DMSA study for the evaluation of patient outcome after urinary tract infection (UTI) [abstract]. Acta Paediatrica, International Journal of Paediatrics 2010;99:81-2. [EMBASE: 70313069]

\section{Ghiro 2002 \{published data only\}}

Ghiro L, Cracco AT, Sartor M, Comacchio S, Zacchello G, Dall'Amico R, et al. Retrospective study of children with acute pyelonephritis. Evaluation of bacterial etiology, antimicrobial susceptibility, drug management and imaging studies. Nephron 2002;90(1):8-15. [MEDLINE: 11744799]

\section{Giorgi 2005 \{published data only\}}

Giorgi LJ Jr, Bratslavsky G, Kogan BA. Febrile urinary tract infections in infants: renal ultrasound remains necessary. Journal of Urology 2005;173(2):568-70. [MEDLINE: 15643258]

\section{Gomez Tellado 1994 \{published data only\}}

Gomez Tellado M, Vela Nieto D, Pais Pineiro E, Candal Alonso J. Comparative sensitivity of intravenous urography, ultrasonography and DMSA scan in the diagnosis of vesicoureteral reflux nephropathy [Sensibilidad comparada de la urografia intravenosa, la ecografia y el DMSA scan en la deteccion de la nefropatia del reflujo vesicoureteral]. Archivos Espanoles de Urologia 1994;47(10):1007-10. [MEDLINE: 7864667]

\section{Gupta 2011 \{published data only\}}

Gupta N, Abulaban O, Goodfellow T, Helm E. Predictors of vesicoureteric reflux in infants with urinary tract infection using National Institute for Clinical Excellence (NICE) criteria [abstract]. Pediatric Radiology 2011;41:S279-80. [EMBASE: 70646880]

\section{Halevy 2013 \{published data only\}}

Halevy R, Smolkin V, Sakran W, Haimovitz L, Koren A. Urinary tract infection in infants: pyelonephritis or not [abstract]. Pediatric Nephrology 2013;28(8):1383-4. [EMBASE: 71127038]

\section{Hamoui 2008 \{published data only\}}

Hamoui N, Hagerty JA, Maizels M, Yerkes EB, Chaviano A, Shore R, et al. Ultrasound fails to delineate significant renal pathology in children with urinary tract infections: a case for dimercapto-succinic acid scintigraphy. Journal of Urology 2008;180(4 Suppl):1639-42. [MEDLINE: 18715573] 
Hannula 2009 \{published data only\}

Hannula A, Venhola M, Renko M, Pokka T, Huttunen NP, Uhari M. Vesicoureteral reflux in children with suspected and proven urinary tract infection [abstract]. Clinical Microbiology \& Infection 2009;15:S568. [EMBASE: 70071936]

Hannula 2010 \{published data only\}

* Hannula A, Venhola M, Renko M, Pokka T, Huttunen NP, Uhari M. Vesicoureteral reflux in children with suspected and proven urinary tract infection. Pediatric Nephrology 2010;25(8):1463-9. [MEDLINE: 20467791]

Hannula 2011 \{published data only\}

Hannula A, Venhola M, Perhomaa M, Pokka T, Renko M, Uhari M. Imaging the urinary tract in children with urinary tract infection. Acta Paediatrica 2011;100(12):e253-9. [MEDLINE: 21711394]

\section{Hansson 1997 \{published data only\}}

Hansson S, Jodal U, Stokland E, Sixt R, Wennerstrom M. 99mTechnetium dimercaptosuccinic acid scintigraphy for prognostic evaluation of children with urinary tract infection [abstract]. Pediatric Nephrology 1997;11:C54.

\section{Hansson 2004 \{published data only\}}

Hansson S, Dhamey M, Sigstrom O, Sixt R, Stokland E, Wennerstrom M, et al. Dimercapto-succinic acid scintigraphy instead of voiding cystourethrography for infants with urinary tract infection. Journal of Urology 2004;172(3):1071-3. [MEDLINE: 15311040]

\section{Haznedaroglu 1996 \{published data only\}}

Haznedaroglu A, Buyan N, Hasanoglu E, Atasever T, Gokcora N. The importance of DMSA scintigraphy in the diagnosis and follow-up of first symptomatic urinary tract infection in childhood [abstract]. Pediatric Nephrology 1996;10:C137.

\section{Herz 2005 \{published data only\}}

Herz DB. Can Dimercaptosiccinic acid scan predict clinically significant vesicoureteral reflux in infants with febrile urinary tract infection? [abstract]. Journal of Urology 2005;173:217-8.

\section{Herz 2010 \{published data only\}}

Herz D, Merguerian P, McQuiston L, Danielson C, Gheen M, Brenfleck L. 5-year prospective results of dimercapto-succinic acid imaging in children with febrile urinary tract infection: Proof that the top-down approach works. Journal of Urology 2010;184(4 Suppl):1703-8. [MEDLINE: 20728131]

\section{Hiraoka 1996 \{published data only\}}

Hiraoka M, Hashimoto G, Hayashi S, Hori C, Tsuchida S, Tsukahara $\mathrm{H}$, et al. Ultrasonography for the detection of ureteric reflux in infants with urinary infection. Acta Paediatrica Japonica 1996;38(3):248-51. [MEDLINE: 8741315]

\section{Hiraoka 1997 \{published data only\}}

Hiraoka M, Hashimoto G, Hori C, Tsukahara H, Konishi Y, Sudo M. Use of ultrasonography in the detection of ureteric reflux in children suspected of having urinary infection. Journal of Clinical Ultrasound 1997;25(4):195-9. [MEDLINE: 9142619]

\section{Honkinen 1986 \{published data only\}}

Honkinen O, Ruuskanen O, Rikalainen H, Makinen EO, Valimaki I. Ultrasonography as a screening procedure in children with urinary tract infection. Pediatric Infectious Disease 1986;5(6):633-5. [MEDLINE: 3540885]

\section{Huang 2008 \{published data only\}}

Huang H P, Lai YC, Tsai IJ, Chen SY, Tsau YK. Renal ultrasonography should be done routinely in children with first urinary tract infections. Urology 2008;71(3):439-43. [MEDLINE: 18342183]

\section{Inoue 2011 \{published data only\}}

Inoue Y, Fujinaga S, Hirano D, Endo A, Nishizaki N, Ohtomo $\mathrm{Y}$, et al. Is it possible to avoid unnecessary voiding cystourethrography by performing acute Technetium-99m dimercaptosuccinic acid scintigraphy and renal ultrasound scanning after first febrile urinary tract infection in children? [abstract]. Pediatric Nephrology 2011;26(5):828. [EMBASE: 70391931]

\section{Jakobsson 1996 \{published data only\}} Jakobsson B, Svensson L. Identifying children at risk after acute pyelonephritis [abstract]. Pediatric Nephrology 1996;10:C138.

\section{Jakobsson 1997 \{published data only\}}

Jakobsson B, Svensson L. Transient pyelonephritic changes on 99mTechnetium-dimercaptosuccinic acid scan for at least five months after infection. Acta Paediatrica 1997;86(8):803-7. [MEDLINE: 9307157]

\section{Jarmolinski 2011 \{published data only\}}

Jarmolinski T, Marciniak SH, Pacanowska B, Dudarenko G. Is it necessary to perform voiding cystourethrography (VCUG) in every child with acute pyelonephritis (APN)? [abstract]. Pediatric Nephrology 2011;26(9):1717-8. [EMBASE: 70530915]

\section{Jaukovic 2009 \{published data only\}}

Jaukovic L, Ajdinovic B, Dopudja M, Krstic Z. Renal scintigraphy in children with vesicoureteral reflux. Indian Journal of Pediatrics 2009;76(10):1023-6. [MEDLINE: 19907934]

\section{Jequier 1985 \{published data only\}}

Jequier S, Forbes PA, Nogrady MB. The value of ultrasonography as a screening procedure in a first-documented urinary tract infection in children. Journal of Ultrasound in Medicine 1985;4(8):393-400. [MEDLINE: 3897561]

Jewkes 1990 \{published data only\}

Jewkes FE, Gupta SC, Wilson B, Postlethwaite RJ, Houston IB. DMSA scanning in acute urinary tract infection and it's relationship to vesico ureteric reflux [abstract]. Pediatric Nephrology 1990;4:C44.

\section{Johnson 1985 \{published data only\}}

Johnson CE, Shurin PA, Marchant CD, Strieter CM, MurdellPanek D, Debaz BP, et al. Identification of children requiring radiologic evaluation for urinary infection. Pediatric Infectious Disease 1985;4(6):656-63. [MEDLINE: 3909120] 
Johnson 1986 \{published data only\}

Johnson CE, DeBaz BP, Shurin PA, DeBartolomeo R. Renal ultrasound evaluation of urinary tract infections in children. [Erratum appears in Pediatrics $1987 \mathrm{Jul} ; 80(1): 121]$. Pediatrics 1986;78(5):871-8. [MEDLINE: 3532020]

\section{Juliano 2013 \{published data only\}}

Juliano TM, Stephany HA, Clayton DB, Thomas JC, Pope JC, Adams MC, et al. Incidence of abnormal imaging and recurrent pyelonephritis after first febrile urinary tract infection in children 2 to 24 months old. Journal of Urology 2013;190(4 Suppl):1505-10. [MEDLINE: 23353046]

\section{Kanellopoulos 2005 \{published data only\}}

Kanellopoulos TA, Vassilakos PJ, Kantzis M, Ellina A, Kolonitsiou F, Papanastasiou DA. Low bacterial count urinary tract infections in infants and young children. European Journal of Pediatrics 2005;164(6):355-61. [MEDLINE: 15739109]

\section{Kanellopoulos 2006 \{published data only\}}

Kanellopoulos TA, Salakos C, Spiliopoulou I, Ellina A, Nikolakopoulou NM, Papanastasiou DA. First urinary tract infection in neonates, infants and young children: a comparative study. Pediatric Nephrology 2006;21(8):1131-7. [MEDLINE: 16810514]

\section{Kangarloo 1985 \{published data only\}}

Kangarloo H, Gold RH, Fine RN, Diament MJ, Boechat MI. Urinary tract infection in infants and children evaluated by ultrasound. Radiology 1985;154(2):367-73. [MEDLINE: 3880909]

\section{Kaplan Bulut 2011 \{published data only\}}

Kaplan Bulut I, Mir S, Sozeri B. Risk factors for VUR in children with upper and lower UTI [abstract]. Pediatric Nephrology 2011;26(9):1714. [EMBASE: 70530905]

\section{Kass 1992 \{published data only\}}

Kass EJ, Fink-Bennett D, Cacciarelli AA, Balon H, Pavlock S. The sensitivity of renal scintigraphy and sonography in detecting nonobstructive acute pyelonephritis. Journal of Urology 1992;148(2 Pt 2):606-8. [MEDLINE: 1640534]

\section{Kass 2000 \{published data only\}}

Kass EJ, Kernen KM, Carey JM. Paediatric urinary tract infection and the necessity of complete urological imaging. $B J U$ International 2000;86(1):94-6. [MEDLINE: 10886091]

\section{Kim 2010 \{published data only\}}

Kim S, Lim I. Comparison of the efficacy of renal ultrasonography, 99m technetium DMSA renal scan and voiding cystourethrography in children with urinary tract infection in Korea [abstract]. Nephrology 2010;15:122. [EMBASE: 70467699]

\section{Kljucevsek 2009 \{published data only\}}

Kljucevsek D, Kljucevsek T, Levart TK, Kenda RB. Ureteric jet Doppler waveform: is it a reliable predictor of vesicoureteric reflux in children?. Pediatric Nephrology 2009;24(2):313-8. [MEDLINE: 18815817]

\section{Krzemien 2002 \{published data only\}}

Krzemien G, Roszkowska-Blaim M, Kostro I, Szmigielska A, Karpinska M, Fracka B. Significance of the acute 99mTc-DMSA renal scintigraphy in children with urinary tract infection [Znaczenie scyntygrafii statycznej nerek z uzyciem 99mTc-DMSA w ostrej fazie zakazenia ukladu moczowego u dzieci]. Polski Merkuriusz Lekarski 2002;12(71):402-4. [EMBASE: 2002184349]

\section{Kuzmanovska 2008 \{published data only\}}

Kuzmanovska D, Sahpazova E, Bogdanovska A, Konstadinova R. Parenchymal renal damage in children with urinary tract infection [Parenhimna bubrezna ostecenja u djece sa infekcijom mokracnog sustava]. Pediatria Croatica 2008;52(Suppl 1):212-7. [EMBASE: 2010638845]

\section{La Scola 2013 \{published data only\}}

La Scola C, De Mutiis C, Hewitt IK, Puccio G, Toffolo A, Zucchetta $\mathrm{P}$, et al. Different guidelines for imaging after first UTI in febrile infants: yield, cost, and radiation. Pediatrics 2013;131(3):e665-71. [MEDLINE: 23439905]

\section{Lee 2009b \{published data only\}}

Lee MD, Lin CC, Huang FY, Tsai TC, Huang CT, Tsai JD. Screening young children with a first febrile urinary tract infection for high-grade vesicoureteral reflux with renal ultrasound scanning and technetium-99m-labeled dimercaptosuccinic acid scanning. Journal of Pediatrics 2009;154(6):797-802. [MEDLINE: 19230904]

\section{Lee 2012b \{published data only\}}

Lee J. Is voiding cystourethrogram necessary in children with a first episode of urinary tract infection? [abstract no: P003-030]. Nephrology 2010;15(Suppl 3):123.

Lee J, Lee JH, Park YS. Risk factors for renal scar formation in infants with first episode of acute pyelonephritis: a prospective clinical study. Journal of Urology 2012;187(3):1032-6. [MEDLINE: 22264451]

\section{Leroy 2010 \{published data only\}}

Leroy S, Vantalon S, Larakeb A, Ducou-Le-Pointe H, Bensman A. Vesicoureteral reflux in children with urinary tract infection: comparison of diagnostic accuracy of renal US criteria. Radiology 2010;225(3):890-8. [MEDLINE: 20501726]

\section{Lim 2010 \{published data only\}}

Lim IS, Kim S. Comparison of the efficacy of renal ultrasonography, 99mTechnetium DMSA renal scan in children with urinary tract infection with vesicourethral reflux in Korea [abstract]. Pediatric Nephrology 2010;25(9):1853. [EMBASE: 70438390]

\section{Lin 2003 \{published data only\}}

Lin KY, Chiu NT, Chen MJ, Lai CH, Huang JJ, Wang YT, et al. Acute pyelonephritis and sequelae of renal scar in pediatric first febrile urinary tract infection. Pediatric Nephrology 2003;18(4):362-5. [MEDLINE: 12700963]

\section{Lytzen 2011 \{published data only\}}

Lytzen R, Thorup J, Cortes D. Experience with the NICE guidelines for imaging studies in children with first 
pyelonephritis. European Journal of Pediatric Surgery 2011;21(5):283-6. [MEDLINE: 21678239]

MacLeod 2011 \{published data only\}

MacLeod L, Balise R, Shortliffe L. Ultrasonography renal parenchymal area predicts vesicoureteral reflux after urinary tract infection [abstract]. Journal of Urology 2011;185(4 Suppl 1):e230. [EMBASE: 70377835]

\section{Mage 1989 \{published data only\}}

Mage K, Zoppardo P, Cohen R, Reinert P, Ponet M. Imaging and the first urinary infection in children. Respective role of each test during the initial evaluation apropos of 122 cases [Imagerie et premiere infection urinaire de l'enfant. Place respective de chaque examen lors du bilan initial a propos de 122 observations]. Journal de Radiologie 1989;70(4):279-83. [MEDLINE: 2677332]

\section{Majd 1991 \{published data only\}}

Majd M, Rushton HG, Jantausch B, Wiedermann BL. Relationship among vesicoureteral reflux, P-fimbriated Escherichia coli, and acute pyelonephritis in children with febrile urinary tract infection. Journal of Pediatrics 1991;119(4):578-85. [MEDLINE: 1681043]

\section{Martin Aguado 2000 \{published data only\}}

Martín Aguado MJ, Canals Baeza A, Vioque López J, Tarazona JL, Flores Serrano J. Technetium-99m-dimercaptosuccinic acid (DMSA) scintigraphy in the first febrile urinary tract infection in children [Gammagrafía con tecnecio-99m-ácido dimercaptosuccínico en el estudio de la primera infección urinaria febril del niño]. Anales Espanoles de Pediatria 2000;52(1):23-30. [MEDLINE: 11003855]

\section{Martinez 2012 \{published data only\}}

Martinez M, Bolong D. TC99-DMSA scan as first investigation to detect vesicoureteral reflux as documented in VCUG: a 10-year retrospective review of DMSA and VCUG imaging in patients with first febrile urinary tract infection: a top-down approach [abstract]. Journal of Urology 2012;187(4 Suppl 1):e249-50. [EMBASE: 70720310]

\section{Masalskiene 2011 \{published data only\}}

Masalskiene J, Pundziene B, Verbliugeviciute G. Comparison of renal ultrasound with fluoroscopic voiding cystourethrography for the detection of vesicoureteral reflux in infants [abstract]. Pediatric Nephrology 2011;26(9):1687. [EMBASE: 70530817]

\section{Massanyi 2013 \{published data only\}}

Massanyi EZ, Preece J, Gupta A, Lin SM, Wang MH. Utility of screening ultrasound after first febrile UTI among patients with clinically significant vesicoureteral reflux. Urology 2013; Vol. 82, issue 4:905-9. [MEDLINE: 23768525]

\section{Matesanz 1998 \{published data only\}}

Matesanz Perez JL, Fernandez Menendez JM, Gracia Chapulle A, Aira Delgado F, Rodriguez Posada R, Ballesteros Garcia S. The utility of gammagraphy with Tc 99-labelled dimercaptosuccinic acid (DMSA) in the protocol for studying urinary infection in a 2nd-level hospital [Utilidad de la gammagrafia con acido dimercaptosuccinico (DMSA) marcado con Tc99 en el protocolo de estudio de la infeccion urinaria en un hospital de segundo nivel]. Anales Espanoles de Pediatria 1998;48(1):21-4. [MEDLINE: 9542222]

\section{Mazigh Mrad 2002 \{published data only\}}

Mazigh Mrad S, Fetni I, Rabeh O, Oubich F, Boukthir S, Barsaoui S. Localisation diagnosis of urinary tract infection study of clinical, biological and radiologigical parameters [Apport des parametres cliniques biologiques et radiologiques dans le diagnostic de localisation de l'infection urinaire]. Tunisie Medicale 2002;80(10):628-32. [EMBASE: 2003041044]

\section{Merguerian 1999 \{published data only\}}

Merguerian PA, Jamal MA, Agarwal SK, McLorie GA, Bagli DJ, Shuckett $B$, et al. Utility of SPECT DMSA renal scanning in the evaluation of children with primary vesicoureteral reflux. Urology 1999;53(5):1024-8. [MEDLINE: 10223500]

Merguerian PA, Jamal MA, Agarwal SK, et al. The utility of dimercaptosuccinic acid (DMSA) renal scanning in the evaluation of children with primary vesicoureteral reflux [abstract]. Pediatrics 1997; Vol. 100, issue 3 Part 2:544.

\section{Mersdorf 1997 \{published data only\}}

Mersdorf A, Rohrmann D, Duque-Reina D, Kleinhans E, Jakse G. The diagnosis of vesicoureteral reflux. Which method is the best? [abstract]. Journal of Urology 1997;157:36.

\section{Mingin 2004 \{published data only\}}

Mingin GC, Nguyen HT, Baskin LS, Harlan S. Abnormal dimercapto-succinic acid scans predict an increased risk of breakthrough infection in children with vesicoureteral reflux.[Erratum appears in J Urol. 2005 May;173(5):1832 Note: Harlan, Susan [added]]. Journal of Urology 2004;172(3):1075-7. [MEDLINE: 15311041]

\section{Mohkam 2010 \{published data only\}}

Mohkam M, Maham S, Rahmani A, Naghi I, Otokesh B, Raiati H, et al. Technetium Tc 99m dimercaptosuccinic acid renal scintigraphy in children with acute pyelonephritis correlation with other imaging tests. Iranian Journal of Kidney Diseases 2010;4(4):297-301. [MEDLINE: 20852370]

\section{Mohkam 2012 \{published data only\}}

Mohkam M, Maham S, Khatami A, Naghi I, Otukesh B, Shamshiri AR, et al. Kidney ultrasonography and dimercaptosuccinic acid scans for revealing vesicoureteral reflux in children with pyelonephritis: a 7-year prospective cohort study of 1500 pyelonephritic patients and 2986 renal units. Nephro-Urology Monthly 2012;4(1):350-5. [EMBASE: 2012043572]

\section{Monakil 2013 \{published data only\}}

Monakil O, Herrera L, Frias IV MV. Concordance of ultrasonographic and voiding cystourethrogram findings in infants and children with urinary tract infection [abstract]. Pediatric Nephrology 2013;28(8):1381-2. [EMBASE: 71127031]

\section{Montini 2008 \{published data only\}}

Montini G, Rigon L, Zucchetta P, Fregonese F, Toffolo A, Gobber D, et al. Prophylaxis after first febrile urinary tract 
infection in children? A multicenter, randomized, controlled, noninferiority trial. Pediatrics 2008;122(5):1064-71. [MEDLINE: 18977988]

\section{Moon 2009 \{published data only\}}

Moon DG, Oh MM, Nam SG, Jin MH, Park HS, Cheon J, et al. Predictive factors for acute scintingraphic lesion and ultimate scar formation in patients with acute febrile UTI [abstract]. Journal of Urology 2009;181(4 Suppl 1):380. [EMBASE: 70113158]

\section{Muensterer 2002 \{published data only\}}

Muensterer OJ. Comprehensive ultrasound versus voiding cysturethrography in the diagnosis of vesicoureteral reflux. European Journal of Pediatrics 2002;161(8):435-7. [MEDLINE: 12172827]

\section{Muga Zuriarrain 2008 \{published data only\}}

Muga Zuriarrain O, Onate Vergara E, Sota Busselo I, Arruebarrena Lizarraga D, Ubetagoyena Arrieta M, Garcia Pardos $\mathrm{C}$, et al. Imaging studies in the first urinary infection with fever in infants: is voiding cystourethrography necessary? [Estudios por imagen en la primera infeccion urinaria con fiebre del lactante. Es necesaria la cistografia miccional?]. Anales de Pediatria 2008;69(6):521-5. [MEDLINE: 19128764]

\section{Nafisi-Moghadam 2011 \{published data only\}}

Nafisi-Moghadam R, Malek M, Najafi F, Shishehsaz B. The value of ultrasound in diagnosing vesicoureteral reflux in young children with urinary tract infection. Acta Medica Iranica 2011;49(9):588-91. [MEDLINE: 22052149]

\section{Nammalwar 2005 \{published data only\}}

Nammalwar BR, Vijayakumar M, Sankar J, Ramnath B, Prahlad N. Evaluation of the use of DMSA in culture positive UTI and culture negative acute pyelonephritis. Indian Pediatrics 2005;42(7):691-6. [MEDLINE: 16085971]

\section{Naseri 2013 \{published data only\}}

Naseri M, Alamdaran SA. Urinary tract infection and predisposing factors in children [abstract]. Pediatric Nephrology 2013;28(8):1379-80. [EMBASE: 71127023]

\section{Nelson 2013 \{published data only\}}

Nelson C, Chow J, Johnson E, Rosoklija I, Tan W. Test characteristics and predictive value of ultrasound as a screening test for GU anomalies among children presenting with UTI [abstract]. Journal of Urology 2013;189(4 Suppl 1):E266. [EMBASE: 71031593]

\section{Ninos 1998 \{published data only\}}

Ninos UE, Martin Hernandez E, Fernandez Posada A, Garcia Ibanez B, Vecilla Rivelles C, Cruz Diaz MA, et al. Voiding cystourethrography in children. Practical consideration concerning irradiation doses [Uretrocistografia en ninos. Consideraciones practicas en relacion con las dosis de irradiacion]. Anales Espanoles de Pediatria 1998;48(4):363-7. [EMBASE: 1998220378]

\section{Orive 2010 \{published data only\}}

Orive B, Madariaga L, Hualde I, Mari A, Comet A. Febrile urinary tract infection in infants. Is cystourethrography necessary? [abstract]. Pediatric Research 2010;68:182.

\section{Otukesh 2011 \{published data only\}}

Otukesh H, Hoseini R, Behzadi AH, Mehran M, Tabbaroki A, Khamesan B, et al. Accuracy of cystosonography in the diagnosis of vesicourethral reflux in children. Saudi Journal of Kidney Diseases \& Transplantation 2011;22(3):488-91. [MEDLINE: 21566305]

\section{Otukesh 2013 \{published data only\}}

Otukesh H. Can DMSA at acute phase of febrile urinary tract infection predict the presence of vesicoureteral reflux and its severity? A prospective blind study [abstract]. Pediatric Nephrology 2013;28(8):1389-90. [EMBASE: 71127059]

\section{Paripovic 2010 \{published data only\}}

Paripovic D, Spasojevic B, Kruscic D, Lomic G, Cvetkovic M, Milovanovic $D$, et al. Low predictive value of ultrasound for detection of vesicouretral reflux in infants after the first acute pyelonephritis [abstract]. Pediatric Nephrology 2010;25(9):1855. [EMBASE: 70438404]

\section{Pecile 1999 \{published data only\}}

Pecile P, Romanello C, Miorin E, Tenore A. Renal parenchymal localization of infection in febrile UTI: relationship with age and vescico-ureteral-reflux [abstract]. Pediatric Nephrology 1999;13:C49.

\section{Pecile 2009 \{published data only\}}

Pecile P, Miorin E, Romanello C, Vidal E, Contardo M, Valent F, et al. Age-related renal parenchymal lesions in children with first febrile urinary tract infections. Pediatrics 2009;124(1):23-9. [MEDLINE: 19564279]

\section{Pennesi 2012 \{published data only\}}

Pennesi M, L'erario I, Travan L, Ventura A. Managing children under 36 months of age with febrile urinary tract infection: a new approach. Pediatric Nephrology 2012;27(4):611-5. [MEDLINE: 22234625]

\section{Printza 2012 \{published data only\}}

Printza N, Farmaki E, Piretzi K, Arsos G, Kollios K, Papachristou F. Acute phase 99mTc-dimercaptosuccinic acid scan in infants with first episode of febrile urinary tract infection. World Journal of Pediatrics 2012;8(1):52-56. [MEDLINE: 22282382]

\section{Puseljic 2003 \{published data only\}}

Puseljic S, Arambasic J, Gardasanic J, Milas V, Puseljic I, Sipl M. The role of tc99m-DMSA scintigraphy in the evaluation of renal parenchymal changes in children with acute urinary tract infection [Vrijednost tc99m-DMSA scintigrafije bubrega u djece s akutnom uroinfekcijom u procjeni tezine parenhimskih lezija]. Acta Medica Croatica 2003;57(1):5-10. [EMBASE: 2003259035]

\section{Quirino 2011 \{published data only\}}

Quirino IG, Silva JM, Diniz JS, Lima EM, Rocha AC, Simoes e Silva AC, et al. Combined use of late phase dimercapto-succinic 
acid renal scintigraphy and ultrasound as first line screening after urinary tract infection in children. Journal of Urology 2011;185(1):258-63. [MEDLINE: 21074813]

\section{Radmayr 2001 \{published data only\}}

Radmayr CH, Klauser A, Frauscher F, Zur Nedden D, Bartsch G. Contrast enhanced ultrasonography in the diagnosis of vesicoureteral reflux in a paediatric population [abstract]. European Urology 2001;39:155.

\section{Radmayr 2002 \{published data only\}}

Radmayr C, Klauser A, Pallwein L, Zurnedden D, Bartsch G, Frauscher $\mathrm{F}$. Contrast enhanced reflux sonography in children: a comparison to standard radiological imaging. Journal of Urology 2002;167(3):1428-30. [MEDLINE: 11832762]

Risi 1990 \{published data only\}

Risi O, Blefari F, Pino P, Facchi E, Lelo G, Tumiati MN. Scintiscanning for the diagnosis of vesicoureteral reflux in childhood [Reflusso vescico-ureterale in eta pediatrica: studio con radionuclidi]. Rassegna Italiana di Chirurgia Pediatrica 1990;32(1):24-6. [EMBASE: 1990160473]

Ristola 2013 \{published data only\}

Ristola MT, Hurme T. NICE guidelines for imaging studies in children with UTI adequate only in boys under the age of 6 months. Pediatric Surgery International 2013;29(3):215-22. [MEDLINE: 23314790]

\section{Rosenberg 1990 \{published data only\}}

Rosenberg AR, Brydon MP, Rossleigh MA, Leighton D, Bass S, Gibbeson M, et al. DMSA scintigraphy in children at the time of acute urinary tract infection: a prospective study [abstract]. Kidney International 1990;38:544-5.

\section{Rosenberg 1992 \{published data only\}}

Rosenberg AR, Rossleigh MA, Brydon MP, Bass SJ, Leighton DM, Farnsworth RH. Evaluation of acute urinary tract infection in children by dimercaptosuccinic acid scintigraphy: a prospective study. Journal of Urology 1992;148(5 Pt 2):1746-9. [MEDLINE: 1331546]

\section{Sadeghi-bojd 2013 \{published data only\}}

Sadeghi-Bojd S. Urinary tract infection and predisposing factor in infant and children in Zahedan (Iran) [abstract]. Pediatric Nephrology 2013;28(8):1386. [EMBASE: 71127046]

\section{Schiavina 1988 \{published data only\}}

Schiavina G, Arrigo G, Mattai del Moro R, D'Urbano M, Morello AC, Vegni M, et al. Urography and sonography in the diagnosis of reflux nephropathy. Contributions to Nephrology 1988;61:220-7.

\section{Schneider 1986 \{published data only\}}

Schneider K. Possibilities and limitations of sonographic reflux diagnosis [Moglichkeiten und grenzen der sonographischen refluxdiagnostil]. Beitrage zur Urologie 1986;4:166-70. [http:// eurekamag.com/research/028/930/028930982.php]

\section{Schneider 1997 \{published data only\}}

Schneider LH, Goldraich NP. Febrile urinary tract infection (UTI) in infants with/without vesicoureteral reflux (VUR): acute changes on DMSA renal scan [abstract]. Pediatric Nephrology 1997;11:C56.

\section{Sciagra 1996 \{published data only\}}

Sciagra R, Materassi M, Rossi V, lenuso R, Danti A, La Cava G. Alternative approaches to the prognostic stratification of mild to moderate primary vesicoureteral reflux in children. Journal of Urology 1996; Vol. 155, issue 6:2052-5. [MEDLINE: 8618333]

\section{Sinha 2013 \{published data only\}}

Sinha R, Mukherjee D, Sengupta J, Saha S, Banerjee S. A prospective evaluation of investigations for urinary tract infection in children less than 5 years of age as per Indian Society of Paediatric Nephrologist (ISPN) guidelines [abstract]. Pediatric Nephrology 2013;28(8):1383. [EMBASE: 71127037]

\section{Siomou 2009 \{published data only\}}

Siomou E, Giapros V, Fotopoulos A, Aasioti M, Papadopoulou F, Serbis A, et al. Implications of $99 \mathrm{mTc}$-DMSA scintigraphy performed during urinary tract infection in neonates. Pediatrics 2009; Vol. 124, issue 3:881-7. [MEDLINE: 19661052]

\section{Smellie 1995 \{published data only\}}

Smellie JM, Rigden SP, Prescod NP. Urinary tract infection: a comparison of four methods of investigation. Archives of Disease in Childhood 1995;72(3):247-50. [MEDLINE: 7741578]

\section{Soccorso 2010 \{published data only\}}

Soccorso G, Wagstaff J, Blakey K, Moss GD, Broadley P, Roberts JP, Godbole P. Investigating febrile UTI in infants: Is a cystogram necessary?. Journal of Pediatric Urology 2010;6(2):148-152. [MEDLINE: 19620025]

Sorkhi 2010 \{published data only\}

Sorkhi H, Rajifar B. Vesicoureteral reflux and renal scarring in infants. Journal of Babol University of Medical Sciences 2010;12(2):41-6. [EMBASE: 2010552001]

\section{Sreenarasimhaiah 1995 \{published data only\}}

Sreenarasimhaiah V, Alon US. Uroradiologic evaluation of children with urinary tract infection: Are both ultrasonography and renal cortical scintigraphy necessary [abstract]. Pediatric Research 1994; Vol. 37, issue 4 Part 2:372A.

Sreenarasimhaiah V, Alon US. Uroradiologic evaluation of children with urinary tract infection: are both ultrasonograpy and renal cortical scintigraphy necessary?. Journal of Pediatrics 1995;127(3):373-7. [MEDLINE: 7658265]

\section{Stokland 1996 \{published data only\}}

Stokland E, Hellstrom M, Jacobsson B, Jodal U, Lundgren P, Sixt R. Early 99mTc dimercaptosuccinic acid (DMSA) scintigraphy in symptomatic first-time urinary tract infection. Acta Paediatrica 1996;85(4):430-6. [MEDLINE: 8740300]

Strife 1989 \{published data only\}

Strife JL, Bisset GS 3rd, Kirks DR, Schlueter FJ, Gelfand MJ, Babcock DS, et al. Nuclear cystography and renal sonography: 
findings in girls with urinary tract infection. AJR. American Journal of Roentgenology 1989;153(1):115-9. [MEDLINE: 2660529]

\section{Subat-Dezulovic 1998 \{published data only\}}

Subat-Dezulovic M, Saina G, Smokvina A. Renal ultrasonography - First imaging procedure in children with urinary infection [Renalna ultrasonografija - Prva dijagnosticka pretraga u djece s dokazanom urinarnom infekcijom]. Paediatria Croatica 1998;42(3-4):139-44. [EMBASE: 1999052128]

\section{Sun 2013 \{published data only\}}

Sheu JN, Sun HL, Chen SM, Chao YH, Ku MS, Liao PF, et al. Diagnostic performance of procalcitonin in predicting dilating vesicoureteral reflux in young children hospitalized with a first febrile urinary tract infection [abstract]. Pediatric Nephrology 2013;28(8):1391-2. [EMBASE: 71127066]

Sun HL, Wu KH, Chen SM, Chao YH, Ku MS, Hung TW, et al. Role of procalcitonin in predicting dilating vesicoureteral reflux in young children hospitalized with a first febrile urinary tract infection. Pediatric Infectious Disease Journal 2013; Vol. 32, issue 9:e348-54. [MEDLINE: 23584577]

\section{Supavekin 2013b \{published data only\}}

Supavekin S, Hunnangkul S, Pravitsitthikul N, Kutanavanishapong S, Chiewvit S, Pattaragarn A, et al. Percentage of serum PMN cells and therapeutic response time predict renal damage in the first episode of urinary tract infection in childhood [abstract]. Pediatric Nephrology 2013;28(8):1384-5. [EMBASE: 71127041$]$

\section{Taheri 2013 \{published data only\}}

Taheri M, Ziaei-Kajbaf T, Valavi E, Fakhrizadeh A, Kalamizadeh M, Javaherizadeh $\mathrm{H}$. Should we do renal ultrasonogram in every child with urinary tract infection?. Pakistan Paediatric Journal 2013;37(4):222-5. [MEDLINE: 2014058820]

\section{Tan 1988 \{published data only\}}

Tan SM, Chee T, Tan KP, Cheng HK, Ooi BC. Role of renal ultrasonography (RUS) and micturating cystourethrogram (MCU) in the assessment of vesico-ureteric reflux (VUR) in children and infants with urinary tract infection (UTI). Singapore Medical Journal 1988;29(2):150-2. [MEDLINE: 3041610]

\section{Tappin 1989 \{published data only\}}

Tappin DM, Mackenzie JR, Murphy AV, Beattie TJ. A prospective study of children with first acute symptomatic E. coli urinary tract infection. Early 99mtechnetium dimercaptosuccinic acid scan appearances [abstract]. Nuclear Medicine Communications 1990; Vol. 11, issue 1:64-5.

Tappin DM, Murphy AV, Mocan H, Shaw R, Beattie TJ, McAllister TA, et al. A prospective study of children with first acute symptomatic E. coli urinary tract infection. Early 99mtechnetium dimercaptosuccinic acid scan appearances. Acta Paediatrica Scandinavica 1989;78(6):923-9. [MEDLINE: 2557721]

\section{Temiz 2006 \{published data only\}}

Temiz Y, Tarcan T, Onol FF, Alpay H, Simsek F. The efficacy of Tc99m dimercaptosuccinic acid (Tc-DMSA) scintigraphy and ultrasonography in detecting renal scars in children with primary vesicoureteral reflux (VUR). International Urology \& Nephrology 2006;38(1):149-52. [MEDLINE: 16502071]

Teoh 2011 \{published data only\}

Teoh CW, Mavinkurve M, Damachi U, Medani S, Waldron M, Coghlan D. Vesico-ureteric reflux and renal scarring in children under 1 year of age with first urinary tract infection [abstract]. Pediatric Nephrology 2011;26(9):1715. [EMBASE: 70530908]

Tepmongkol 2002 \{published data only\}

Tepmongkol S, Chotipanich C, Sirisalipoch S, Chaiwatanarat T, Vilaichon AO, Wattana D. Relationship between vesicoureteral reflux and renal cortical scar development in Thai children: the significance of renal cortical scintigraphy and direct radionuclide cystography. Journal of the Medical Association of Thailand 2002;85 Suppl 1:S203-9. [MEDLINE: 12188413]

Tramma 2010 \{published data only\}

Tramma D, Gerasimou G, Papadopoulou A. First time urinary tract infection in children. Clinical, laboratory findings and risk of renal scarring [abstract]. Pediatric Nephrology 2010;25(9):1857. [EMBASE: 70438415]

\section{Tsai 2004 \{published data only\}}

Tsai YC, Hsu CY, Lin GJ, Wang CJ, Cheng CH, Huang YH, et al. Vesicoureteral reflux in hospitalized children with urinary tract infection: the clinical value of pelvic ectasia on renal ultrasound, inflammatory responses and demographic data. Chang Gung Medical Journal 2004; Vol. 27, issue 6:436-42. [MEDLINE: 15455544]

Tse 2009 \{published data only\}

Tse NK, Yuen SL, Chiu MC, Lai WM, Tong PC. Imaging studies for first urinary tract infection in infants less than 6 months old: can they be more selective?. Pediatric Nephrology 2009;24(9):1699-703. [MEDLINE: 19444481]

\section{Valavi 2011 \{published data only\}}

Valavi E, Ahmadzadeh A, Ziaee Kajbaf T, Nicfar R, Aminzadeh M, Najafi R. Clinical correlation between findings of renal scintigraphy and clinical / Laboratory findings in children with febrile UTI [abstract]. Iranian Journal of Kidney Diseases 2011;5:10. [EMBASE: 70539623]

Venhola 2010 \{published data only\}

Venhola M, Huttunen NP, Renko M, Pokka T, Uhari M. Practice guidelines for imaging studies in children after the first urinary tract infection. Journal of Urology 2010;184(1):325-8. [MEDLINE: 20488488]

\section{Verber 1988 \{published data only\}}

Verber IG, Strudley MR, Meller ST. 99mTc dimercaptosuccinic acid (DMSA) scan as first investigation of urinary tract infection. Archives of Disease in Childhood 1988; Vol. 63, issue 11:1320-5. [MEDLINE: 2849382]

\section{Wong 2010 \{published data only\}}

Wong SN, Tse NK, Lee KP, Yuen SF, Leung LC, Pau BC, et al. Evaluating different imaging strategies in children after

Dimercaptosuccinic acid scan or ultrasound in screening for vesicoureteral reflux among children with urinary tract infections (Review) 
first febrile urinary tract infection. Pediatric Nephrology 2010;25(10):2083-91. [MEDLINE: 20556431]

\section{Wongbencharat 2013 \{published data only\}}

Wongbencharat $\mathrm{K}$. Challenging radiologic investigation in infants with first febrile urinary tract infections [abstract]. Pediatric Nephrology 2013;28(8):1381. [EMBASE: 71127029]

Wu 2004 \{published data only\}

Wu CY, Chiu PC, Hsieh KS, Chiu CL, Shih CH, Chiou YH. Childhood urinary tract infection: a clinical analysis of 597 cases. Acta Paediatrica Taiwanica 2004;45(6):328-33. [MEDLINE: 15868848]

\section{Wu 2011 \{published data only\}}

Wu JH, Chiou YH, Chang JT, Wang HP, Chen YY, Hsieh KS. Urinary tract infection in infants: a single-center clinical analysis in southern Taiwan. Pediatrics \& Neonatology 2011;53(5):283-8. [MEDLINE: 23084719]

\section{Zaki 2005 \{published data only\}}

Zaki M, Badawi M, Al Mutari G, Ramadan D, Adul Rahman M. Acute pyelonephritis and renal scarring in Kuwaiti children: a follow-up study using 99mTc DMSA renal scintigraphy. Pediatric Nephrology 2005;20(8):1116-9. [MEDLINE: 15973531]

\section{Zhang 2010 \{published data only\}}

Zhang X, Xu H. The efficacy of acute DMSA scan in predicting VUR in Chinese young children with febrile UTI [abstract]. Pediatric Nephrology 2010;25(9):1848. [EMBASE: 70438367]

\section{Zhang 2013 \{published data only\}}

Zhang X, Xu H, Shen Q, Sun L, Cao Q, Zhai Y, et al. Accuracy of early DMSA scan in predicting dilating VUR in young children with febrile UTI [abstract]. Pediatric Nephrology 2013;28(8):1392. [EMBASE: 71127067 ]

\section{Zhang 2014 \{published data only\}}

Zhang X, Xu H, Zhao RF. Efficacy of acute (99m)Tcdimercaptosuccinic acid scan in predicting vesicoureteral reflux among young children with febrile urinary tract infection. Zhonghua Erke Zazhi [Chinese Journal of Pediatrics] 2010; Vol. 48, issue 5:334-7. [MEDLINE: 20654031]

Zhang X, Xu H, Zhou L, Cao Q, Shen Q, Sun L, et al. Accuracy of early DMSA scan for VUR in young children with febrile UTI. Pediatrics 2014;133(1):e30-8. [MEDLINE: 24366989]

\section{Zhao 2006 \{published data only\}}

Zhao RF, Zeng JH, Ji ZY, Lv XM, Wu H, Li YW, et al. Evaluation and analysis of imaging modalities in children with first urinary tract infection. Chinese Journal of Medical Imaging Technology 2006;22(7):1083-6. [EMBASE: 2006401888]

\section{Zocchi 1988 \{published data only\}}

Zocchi M, Ferrero CG. Importance of sonography in the evaluation of urinary tract infections in children. Radiologia Medica 1988;76(6):597-600. [EMBASE: 1989032609]

\section{References to studies awaiting assessment}

\section{Alvarez 2007 \{published data only\}}

Alvarez MD, Estevez RR, de la Paz MT, Garcia MM. Low risk of renal damage in new borns with acquired in the community urinary tract infection [Bajo riesgo de dano renal cicatrizal en recien nacidos con infeccion del tracto urinario adquirida en la comunidad]. Saludarte 2007;5(2):142-54. [EMBASE: 2007398631]

\section{Maioli 1987 \{published data only\}}

Maioli A, Dell Vecchio E. Ultrasonography in diagnosis of recurrent urinary tract infections in children: comparison with urography and micturating cystouretrography [L'ecotomografia nell'iter diagnostico delle infezioni ricorrenti delle vie urinarie in eta pediatrica: confronto con altre metodiche strumentali (urografia e cistouretrografia minzionale)]. Italian Current Radiology 1987;6(3):293-8. [EMBASE: 1988013468]

\section{Additional references}

\section{AAP 2011}

Subcommittee on Urinary Tract Infection, Steering Committee on Quality Improvement and Management, Roberts KB. Urinary tract infection: clinical practice guideline for the diagnosis and management of the initial UTI in febrile infants and children 2 to 24 months. Pediatrics 2011;128(3):595-610. [MEDLINE: 21873693]

\section{Brandstrom 2010}

Brandstrom P, Neveus T, Sixt R, Stokland E, Jodal U, Hansson S. The Swedish reflux trial in children: IV. Renal damage. Journal of Urology 2010;184(1):292-7. [MEDLINE: 20494369]

\section{Craig 2000}

Craig JC, Wheeler DM, Irwig L, Howman-Giles RB. How accurate is dimercaptosuccinic acid scintigraphy for the diagnosis of acute pyelonephritis? A meta-analysis of experimental studies. Journal of Nuclear Medicine 2000;41(6):986-93. [MEDLINE: 10855622]

\section{Hayen 2010}

Hayen A, Macaskill P, Irwig L, Bossuyt P. Appropriate statistical methods are required to assess diagnostic tests for replacement, add-on, and triage. Journal of Clinical Epidemiology 2010;63(8):883-91. [MEDLINE: 20079607]

\section{Hoberman 1994}

Hoberman A, Wald ER, Reynolds EA, Penchansky L, Charron M. Pyuria and bacteriuria in urine specimens obtained by catheter from young children with fever. Journal of Pediatrics 1994;124(4):513-9. [MEDLINE: 8151463]

\section{Hoberman 2014}

Hoberman A, Chesney RW, RIVUR Trial Investigators. Antimicrobial prophylaxis for children with vesicoureteral reflux. New England Journal of Medicine 2014;371(11):1072-3. [MEDLINE: 25207771] 


\section{IRSC 1981}

Anonymous. Medical versus surgical treatment of primary vesicoureteral reflux: report of the International Reflux Study Committee. Pediatrics 1981;67(3):392-400. [MEDLINE: 7017578]

\section{Nagler 2011}

Nagler EV, Williams G, Hodson EM, Craig JC. Interventions for primary vesicoureteric reflux. Cochrane Database of Systematic Reviews 2011, Issue 6. [DOI: 10.1002/14651858.CD001532.pub4]

\section{NICE 2007}

National Institute for Health and Care Excellence. Urinary tract infection in under 16s: diagnosis and management 2007 [CG54]. www.nice.org.uk/guidance/cg54 (accessed 16 February 2016).

\section{Shaikh 2010}

Shaikh N, Ewing AL, Bhatnagar S, Hoberman A. Risk of renal scarring in children with a first urinary tract infection: a systematic review. Pediatrics 2010;126(6):1084-91. [MEDLINE: 21059720]

\section{CHARACTERISTICS OF STUDIES}

Characteristics of included studies [ordered by study ID]

\section{Shaikh 2014}

Shaikh N, Craig JC, Rovers MM, Da Dalt L, Gardikis S, Hoberman A, et al. Identification of children and adolescents at risk for renal scarring after a first urinary tract infection: a meta-analysis with individual patient data. JAMA Pediatrics 2014;168(10):893-900. [MEDLINE: 25089634]

\section{Whiting 2011}

Whiting PF, Rutjes AW, Westwood ME, Mallett S, Deeks JJ, Reitsma JB, et al. QUADAS-2: a revised tool for the quality assessment of diagnostic accuracy studies. Annals of Internal Medicine 2011;155(8):529-36. [MEDLINE: 22007046]

\section{References to other published versions of this review \\ Spingarn 2013}

Spingarn RB, Shaikh N. Dimercaptosuccinic acid scan versus ultrasound in screening for vesicoureteral reflux among children with urinary tract infections. Cochrane Database of Systematic Reviews 2013, Issue 7. [DOI: 10.1002/14651858.CD010657]

* Indicates the major publication for the study

\section{Agras 2007}

\section{Study characteristics}

\begin{tabular}{ll}
\hline Patient sampling & Prospective \\
\hline Patient characteristics and setting & $\begin{array}{l}217 \text { children aged } 2 \text { months to } 11 \text { years with pyelonephritis who } \\
\text { were hospitalised and had increased ESR/CRP and did not have a } \\
\text { recurrent UTI during follow-up }\end{array}$ \\
\hline
\end{tabular}

Index tests DMSA

\begin{tabular}{ll}
\hline Target condition and reference standard(s) & VUR, VCUG \\
\hline Flow and timing & $\begin{array}{l}\text { DMSA was obtained within first week of fever and VCUG } 6 \text { to } 8 \\
\text { weeks after APN }\end{array}$ \\
\hline Comparative & \\
\hline
\end{tabular}

Notes Males $>$ females, age up to 11 years

\section{Methodological quality}

\begin{tabular}{llll}
\hline Item & $\begin{array}{l}\text { Authors' judge- } \\
\text { ment }\end{array}$ & Risk of bias & $\begin{array}{l}\text { Applicability con- } \\
\text { cerns }\end{array}$ \\
\hline
\end{tabular}

\section{DOMAIN 1: Patient Selection}

Was a consecutive or random sample of patients enrolled? Unclear

Was a case-control design avoided? Yes


Agras 2007 (Continued)

\begin{tabular}{lll}
\hline Low & High \\
\hline
\end{tabular}

\section{DOMAIN 2: Index Test All tests}

Were the index test results interpreted without knowledge of Yes the results of the reference standard?

If a threshold was used, was it pre-specified? Yes

\begin{tabular}{|c|c|c|c|}
\hline & & Low & Low \\
\hline \multicolumn{4}{|l|}{ DOMAIN 3: Reference Standard } \\
\hline $\begin{array}{l}\text { Is the reference standards likely to correctly classify the target } \\
\text { condition? }\end{array}$ & Yes & & \\
\hline \multirow[t]{2}{*}{$\begin{array}{l}\text { Were the reference standard results interpreted without knowl- } \\
\text { edge of the results of the index tests? }\end{array}$} & Unclear & & \\
\hline & & Low & Low \\
\hline \multicolumn{4}{|l|}{ DOMAIN 4: Flow and Timing } \\
\hline $\begin{array}{l}\text { Was there an appropriate interval between index test and refer- } \\
\text { ence standard? }\end{array}$ & Yes & & \\
\hline Did all patients receive the same reference standard? & Yes & & \\
\hline \multirow[t]{2}{*}{ Were all patients included in the analysis? } & Yes & & \\
\hline & & Low & \\
\hline
\end{tabular}

\section{Alon 1986}

\section{Study characteristics}

\begin{tabular}{ll}
\hline Patient sampling & Prospective \\
\hline Patient characteristics and setting & $\begin{array}{l}81 \text { children aged } 12 \text { weeks to } 12 \text { years with UTI who were hospi- } \\
\text { talised or seen at the outpatient clinic with symptomatic UTI; radi- } \\
\text { ologic evaluation was indicated as per standard of care at the time }\end{array}$ \\
\hline Index tests & US \\
\hline Target condition and reference standard(s) & VUR, VCUG \\
\hline Flow and timing & $\begin{array}{l}\text { US was performed within } 4 \text { days of hospitalisation and VCUG with- } \\
\text { in } 4 \text { to } 6 \text { weeks after of completing antibiotics }\end{array}$
\end{tabular}

\section{Comparative}

\section{Notes}


Alon 1986 (Continued)

Methodological quality

\begin{tabular}{llll}
\hline Item & $\begin{array}{l}\text { Authors' judge- } \\
\text { ment }\end{array}$ & Risk of bias & $\begin{array}{l}\text { Applicability con- } \\
\text { cerns }\end{array}$ \\
\hline
\end{tabular}

\section{DOMAIN 1: Patient Selection}

\begin{tabular}{lll}
\hline Was a consecutive or random sample of patients enrolled? & No \\
\hline Was a case-control design avoided? & Yes & \\
\hline Did the study avoid inappropriate exclusions? & Yes & Low \\
\hline
\end{tabular}

DOMAIN 2: Index Test All tests

Were the index test results interpreted without knowledge of Yes the results of the reference standard?

If a threshold was used, was it pre-specified? Unclear

\begin{tabular}{lll}
\hline Low & Low \\
\hline
\end{tabular}

\section{DOMAIN 3: Reference Standard}

Is the reference standards likely to correctly classify the target Yes condition?

Were the reference standard results interpreted without knowl- Yes edge of the results of the index tests?

\begin{tabular}{lll}
\hline DOMAIN 4: Flow and Timing & Low \\
\hline $\begin{array}{l}\text { Was there an appropriate interval between index test and refer- } \\
\text { ence standard? }\end{array}$ & Yes \\
\hline Did all patients receive the same reference standard? & Yes \\
\hline Were all patients included in the analysis? & & Low \\
\hline
\end{tabular}

\section{Alon 1999 \\ Study characteristics}

\begin{tabular}{ll}
\hline Patient sampling & $\begin{array}{l}\text { Retrospective study of patients with complete radiological evalua- } \\
\text { tion }\end{array}$ \\
\hline Patient characteristics and setting & $\begin{array}{l}100 \text { children aged } 1 \text { month to } 18 \text { years admitted for a first febrile } \\
\text { UTI or APN }\end{array}$ \\
\hline
\end{tabular}


Alon 1999 (Continued)

Index tests US

Target condition and reference standard(s)

VUR, VCUG

Flow and timing

US done during hospitalisation and VCUG 4 to 6 weeks after acute infection; 100/124 received VCUG

Comparative

Notes Only "major" ultrasound abnormalities considered

\section{Methodological quality}

\begin{tabular}{llll}
\hline Item & $\begin{array}{l}\text { Authors' judge- } \\
\text { ment }\end{array}$ & Risk of bias & $\begin{array}{l}\text { Applicability con- } \\
\text { cerns }\end{array}$ \\
\hline
\end{tabular}

\section{DOMAIN 1: Patient Selection}

Was a consecutive or random sample of patients enrolled?

Was a case-control design avoided?

Did the study avoid inappropriate exclusions?

\section{No}

Yes

Yes

High Low

\section{DOMAIN 2: Index Test All tests}

Were the index test results interpreted without knowledge of Unclear the results of the reference standard?

\begin{tabular}{llll}
\hline If a threshold was used, was it pre-specified? & Unclear & \\
\hline & High & Low \\
\hline
\end{tabular}

\section{DOMAIN 3: Reference Standard}

Is the reference standards likely to correctly classify the target Yes condition?

Were the reference standard results interpreted without knowl- Unclear edge of the results of the index tests?

\begin{tabular}{lll}
\hline & Low & Low \\
\hline DOMAIN 4: Flow and Timing &
\end{tabular}

Was there an appropriate interval between index test and refer- Yes ence standard?

Did all patients receive the same reference standard? Yes

Were all patients included in the analysis? No

High 
Ansari Gilani 2010

\section{Study characteristics}

\begin{tabular}{ll}
\hline Patient sampling & Prospective \\
\hline Patient characteristics and setting & $\begin{array}{l}119 \text { children aged } 1 \text { to } 120 \text { months with first UTI; setting not speci- } \\
\text { fied }\end{array}$ \\
\hline Index tests & DMSA \\
\hline Target condition and reference standard(s) & VUR, VCUG \\
\hline Flow and timing & $\begin{array}{l}\text { All had DMSA within 1 week and 71/119 VCUG 4 weeks after admis- } \\
\text { sion }\end{array}$ \\
\hline
\end{tabular}

Comparative

Notes

\section{Methodological quality}

\begin{tabular}{llll}
\hline Item & $\begin{array}{l}\text { Authors' judge- } \\
\text { ment }\end{array}$ & Risk of bias & $\begin{array}{l}\text { Applicability con- } \\
\text { cerns }\end{array}$
\end{tabular}

\section{DOMAIN 1: Patient Selection}

\begin{tabular}{lcc}
\hline Was a consecutive or random sample of patients enrolled? & Yes \\
\hline Was a case-control design avoided? & Yes & \\
\hline Did the study avoid inappropriate exclusions? & Yes & Low \\
\hline
\end{tabular}

\section{DOMAIN 2: Index Test All tests}

Were the index test results interpreted without knowledge of Yes the results of the reference standard?

If a threshold was used, was it pre-specified?

\begin{tabular}{lll}
\hline Low & Low \\
\hline
\end{tabular}

\section{DOMAIN 3: Reference Standard}

Is the reference standards likely to correctly classify the target Yes condition?

Were the reference standard results interpreted without knowl- Unclear edge of the results of the index tests?

\begin{tabular}{lll}
\hline & Low & Low \\
\hline DOMAIN 4: Flow and Timing & \\
\hline
\end{tabular}


Ansari Gilani 2010 (Continued)

Was there an appropriate interval between index test and refer- Yes ence standard?

Did all patients receive the same reference standard?

Yes

Were all patients included in the analysis?

No

High

Ataei 2005

\section{Study characteristics}

\begin{tabular}{|c|c|c|c|}
\hline Patient sampling & \multicolumn{3}{|l|}{ Prospective } \\
\hline Patient characteristics and setting & \multicolumn{3}{|c|}{$\begin{array}{l}52 \text { children aged } 5 \text { to } 12 \text { years (restricted age range) admitted to } \\
\text { the hospital with suspected pyelonephritis and a high CRP who } \\
\text { were admitted to hospital }\end{array}$} \\
\hline Index tests & \multicolumn{3}{|l|}{ DMSA } \\
\hline Target condition and reference standard(s) & \multicolumn{3}{|l|}{ VUR, VCUG } \\
\hline Flow and timing & \multicolumn{3}{|c|}{$\begin{array}{l}\text { DMSA was done within days of admission and VCUG within } 5 \text { to } 7 \\
\text { days of admission }\end{array}$} \\
\hline \multicolumn{4}{|l|}{ Comparative } \\
\hline \multicolumn{4}{|l|}{ Notes } \\
\hline \multicolumn{4}{|l|}{ Methodological quality } \\
\hline Item & $\begin{array}{l}\text { Authors' judge- } \\
\text { ment }\end{array}$ & Risk of bias & $\begin{array}{l}\text { Applicability con- } \\
\text { cerns }\end{array}$ \\
\hline \multicolumn{4}{|l|}{ DOMAIN 1: Patient Selection } \\
\hline Was a consecutive or random sample of patients enrolled? & Unclear & & \\
\hline Was a case-control design avoided? & Yes & & \\
\hline \multirow[t]{2}{*}{ Did the study avoid inappropriate exclusions? } & Yes & & \\
\hline & & Low & High \\
\hline
\end{tabular}

\section{DOMAIN 2: Index Test All tests}

Were the index test results interpreted without knowledge of Yes the results of the reference standard?

If a threshold was used, was it pre-specified? 
Ataei 2005 (Continued)

\section{DOMAIN 3: Reference Standard}

Is the reference standards likely to correctly classify the target Yes condition?

Were the reference standard results interpreted without knowl- Unclear edge of the results of the index tests?

Low Low

\section{DOMAIN 4: Flow and Timing}

Was there an appropriate interval between index test and refer- Yes ence standard?

\begin{tabular}{ll}
\hline Did all patients receive the same reference standard? Yes \\
\hline
\end{tabular}

Were all patients included in the analysis? Yes

Low

Ataei 2008

\section{Study characteristics}

\begin{tabular}{ll}
\hline Patient sampling & Prospective \\
\hline Patient characteristics and setting & $\begin{array}{l}102 \text { patients aged } 1 \text { month to } 12 \text { years admitted to the hospital } \\
\text { with high suspicion of pyelonephritis and a high CRP/ESR }\end{array}$ \\
\hline Index tests & DMSA \\
\hline Target condition and reference standard(s) & VUR, VCUG \\
\hline Flow and timing & $\begin{array}{l}\text { DMSA within first days after admission, VCUG within } 5 \text { to } 7 \text { days of } \\
\text { hospitalisation but before patient was discharged. } 98 / 102 \text { patients } \\
\text { included in the analysis }\end{array}$ \\
\hline
\end{tabular}

Comparative

Notes Results in terms of renal units

\section{Methodological quality}

\begin{tabular}{llll}
\hline Item & $\begin{array}{l}\text { Authors' judge- } \\
\text { ment }\end{array}$ & Risk of bias & $\begin{array}{l}\text { Applicability con- } \\
\text { cerns }\end{array}$
\end{tabular}

\section{DOMAIN 1: Patient Selection}

\begin{tabular}{ll}
\hline Was a consecutive or random sample of patients enrolled? & Unclear \\
\hline Was a case-control design avoided? & Yes \\
\hline Did the study avoid inappropriate exclusions? & Yes \\
\hline
\end{tabular}


Ataei 2008 (Continued)

Low

High

\section{DOMAIN 2: Index Test All tests}

Were the index test results interpreted without knowledge of

the results of the reference standard?

If a threshold was used, was it pre-specified?

Yes

Low Low

\section{DOMAIN 3: Reference Standard}

Is the reference standards likely to correctly classify the target Yes condition?

Were the reference standard results interpreted without knowl- Unclear edge of the results of the index tests?

Low

Low

\section{DOMAIN 4: Flow and Timing}

Was there an appropriate interval between index test and refer- Yes ence standard?

Did all patients receive the same reference standard?

Yes

Were all patients included in the analysis?

No

Low

Calisti 2005

\section{Study characteristics}

\begin{tabular}{ll}
\hline Patient sampling & Prospective \\
\hline Patient characteristics and setting & 147 patients aged 1 to 24 months admitted with a first UTI \\
\hline Index tests & VUR, VCUG \\
\hline Target condition and reference standard(s) & Unclear timing of US and VCUG \\
\hline Flow and timing & \\
\hline Comparative & $\begin{array}{l}\text { Authors' judge- } \\
\text { ment }\end{array}$ \\
\hline Notes & Risk of bias \\
\hline Methodological quality & $\begin{array}{l}\text { Applicability con- } \\
\text { cerns }\end{array}$
\end{tabular}

Dimercaptosuccinic acid scan or ultrasound in screening for vesicoureteral reflux among children with urinary tract infections (Review) 
Calisti 2005 (Continued)

DOMAIN 1: Patient Selection

\begin{tabular}{llll}
\hline Was a consecutive or random sample of patients enrolled? & Unclear \\
\hline Was a case-control design avoided? & Yes & \\
\hline Did the study avoid inappropriate exclusions? & Yes & Low & Low \\
\hline
\end{tabular}

\section{DOMAIN 2: Index Test All tests}

Were the index test results interpreted without knowledge of Yes the results of the reference standard?

\begin{tabular}{lll}
\hline If a threshold was used, was it pre-specified? & Unclear & \\
\hline Low & Low \\
\hline
\end{tabular}

\section{DOMAIN 3: Reference Standard}

Is the reference standards likely to correctly classify the target Yes condition?

Were the reference standard results interpreted without knowl- Yes edge of the results of the index tests?

Low Low

\section{DOMAIN 4: Flow and Timing}

Was there an appropriate interval between index test and refer- Unclear ence standard?

Did all patients receive the same reference standard? Yes

Were all patients included in the analysis? Yes

Low

\section{Camacho 2004}

\section{Study characteristics}

\begin{tabular}{ll}
\hline Patient sampling & Prospective \\
\hline Patient characteristics and setting & $\begin{array}{l}142 \text { children aged } 1 \text { month to } 12 \text { years with a first episode of } \\
\text { febrile UTI; setting not specified }\end{array}$ \\
\hline Index tests & DMSA \\
\hline Target condition and reference standard(s) & VUR, VCUG \\
\hline
\end{tabular}




\section{Camacho 2004 (Continued)}

Flow and timing

DMSA within 5 days of presentation and VCUG after acute phase of illness

\section{Comparative}

\section{Notes}

\section{Methodological quality}

\begin{tabular}{llll}
\hline Item & $\begin{array}{l}\text { Authors' judge- } \\
\text { ment }\end{array}$ & Risk of bias & $\begin{array}{l}\text { Applicability con- } \\
\text { cerns }\end{array}$
\end{tabular}

\section{DOMAIN 1: Patient Selection}

\begin{tabular}{lcc}
\hline Was a consecutive or random sample of patients enrolled? & Yes \\
\hline Was a case-control design avoided? & Yes & \\
\hline Did the study avoid inappropriate exclusions? & Yes & Low \\
\hline
\end{tabular}

\section{DOMAIN 2: Index Test All tests}

Were the index test results interpreted without knowledge of Yes the results of the reference standard?

\begin{tabular}{lll}
\hline If a threshold was used, was it pre-specified? & Yes & Low \\
\hline
\end{tabular}

\section{DOMAIN 3: Reference Standard}

Is the reference standards likely to correctly classify the target Yes condition?

Were the reference standard results interpreted without knowl- Unclear edge of the results of the index tests?

Low Low

\section{DOMAIN 4: Flow and Timing}

Was there an appropriate interval between index test and refer- Unclear ence standard?

Did all patients receive the same reference standard? Yes

Were all patients included in the analysis?

Yes 
Cascio 2002

\section{Study characteristics}

Patient sampling

Retrospective study of patients with complete radiological evaluation

\begin{tabular}{lll}
\hline Patient characteristics and setting & 57 children aged 0 to 8 weeks hospitalised with a first UTI \\
\hline Index tests & DMSA & VUR, VCUG \\
\hline Target condition and reference standard(s) & $\begin{array}{l}\text { DMSA within } 72 \text { hours of admission and VCUG at least } 6 \text { weeks af- } \\
\text { ter UTI }\end{array}$ \\
\hline Flow and timing & \begin{tabular}{l} 
Data in terms of renal units, DMSA threshold not specified \\
\hline Comparative
\end{tabular} & $\begin{array}{l}\text { Authors' judge- } \\
\text { ment }\end{array}$ \\
\hline Notes & Risk of bias & $\begin{array}{l}\text { Applicability con- } \\
\text { cerns }\end{array}$
\end{tabular}

\section{DOMAIN 1: Patient Selection}

\begin{tabular}{lll}
\hline Was a consecutive or random sample of patients enrolled? & No \\
\hline Was a case-control design avoided? & Yes & \\
\hline Did the study avoid inappropriate exclusions? & No & High \\
\hline
\end{tabular}

\section{DOMAIN 2: Index Test All tests}

Were the index test results interpreted without knowledge of Yes the results of the reference standard?

\begin{tabular}{lll}
\hline Low & Low \\
\hline
\end{tabular}

\section{DOMAIN 3: Reference Standard}

Is the reference standards likely to correctly classify the target Yes condition?

Were the reference standard results interpreted without knowl- Unclear edge of the results of the index tests?

\begin{tabular}{l}
\hline Low \\
\hline DOMAIN 4: Flow and Timing \\
\hline $\begin{array}{l}\text { Was there an appropriate interval between index test and refer- } \quad \text { Unclear } \\
\text { ence standard? }\end{array}$ \\
\hline $\begin{array}{l}\text { Dimercaptosuccinic acid scan or ultrasound in screening for vesicoureteral reflux among children with urinary tract infections (Review) } \\
\text { Copyright } \odot 2016 \text { The Cochrane Collaboration. Published by John Wiley \& Sons, Ltd. }\end{array}$
\end{tabular}


Cascio 2002 (Continued)

Did all patients receive the same reference standard?

Were all patients included in the analysis?
Yes

Yes

Low

\section{Cleper 2004}

\section{Study characteristics}

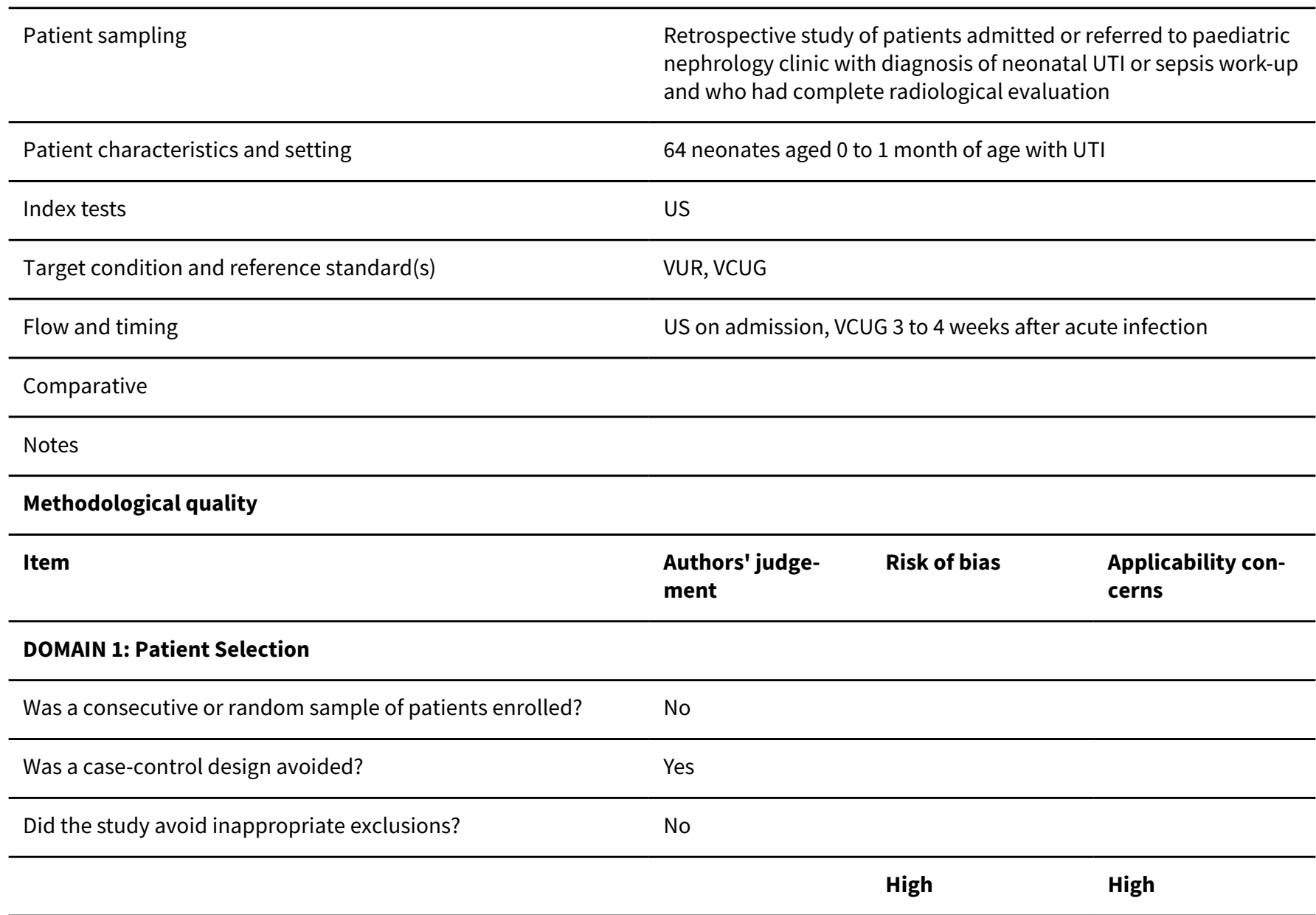

DOMAIN 2: Index Test All tests

Were the index test results interpreted without knowledge of Yes the results of the reference standard?

If a threshold was used, was it pre-specified?

Yes

\begin{tabular}{l}
\hline Low \\
\hline DOMAIN 3: Reference Standard \\
\hline $\begin{array}{l}\text { Is the reference standards likely to correctly classify the target Yes } \\
\text { condition? }\end{array}$ \\
\hline $\begin{array}{l}\text { Dimercaptosuccinic acid scan or ultrasound in screening for vesicoureteral reflux among children with urinary tract infections (Review) } \\
\text { Copyright } \odot 2016 \text { The Cochrane Collaboration. Published by John Wiley \& Sons, Ltd. }\end{array}$
\end{tabular}

Copyright $\odot 2016$ The Cochrane Collaboration. Published by John Wiley \& Sons, Ltd. 
Cleper 2004 (Continued)

Were the reference standard results interpreted without knowl- Unclear edge of the results of the index tests?

Low

Low

\section{DOMAIN 4: Flow and Timing}

Was there an appropriate interval between index test and refer- Yes ence standard?

Did all patients receive the same reference standard?

Yes

Were all patients included in the analysis?

Yes

Low

\section{Doganis 2007}

\section{Study characteristics}

\begin{tabular}{|c|c|c|c|}
\hline Patient sampling & \multicolumn{3}{|l|}{ Prospective } \\
\hline Patient characteristics and setting & \multicolumn{3}{|c|}{$\begin{array}{l}278 \text { infants aged }<12 \text { months with first febrile UTI who were ad- } \\
\text { mitted to the hospital; males }>\text { females }\end{array}$} \\
\hline Index tests & \multicolumn{3}{|l|}{ DMSA } \\
\hline Target condition and reference standard(s) & \multicolumn{3}{|l|}{ VUR, VCUG } \\
\hline Flow and timing & \multicolumn{3}{|c|}{$\begin{array}{l}\text { DMSA within } 18 \text { days of admission and VCUG before discharge; } 9 \\
\text { parents refused VCUG ( } 269 / 278 \text { had complete data) }\end{array}$} \\
\hline \multicolumn{4}{|l|}{ Comparative } \\
\hline \multicolumn{4}{|l|}{ Notes } \\
\hline \multicolumn{4}{|l|}{ Methodological quality } \\
\hline Item & $\begin{array}{l}\text { Authors' judge- } \\
\text { ment }\end{array}$ & Risk of bias & $\begin{array}{l}\text { Applicability con- } \\
\text { cerns }\end{array}$ \\
\hline \multicolumn{4}{|l|}{ DOMAIN 1: Patient Selection } \\
\hline Was a consecutive or random sample of patients enrolled? & Yes & & \\
\hline Was a case-control design avoided? & Yes & & \\
\hline \multirow[t]{2}{*}{ Did the study avoid inappropriate exclusions? } & Yes & & \\
\hline & & Low & Low \\
\hline
\end{tabular}

\section{DOMAIN 2: Index Test All tests}


Doganis 2007 (Continued)

Were the index test results interpreted without knowledge of Unclear the results of the reference standard?

\section{DOMAIN 3: Reference Standard}

Is the reference standards likely to correctly classify the target Yes condition?

Were the reference standard results interpreted without knowl- Unclear edge of the results of the index tests?

\begin{tabular}{lll}
\hline LOMAIN 4: Flow and Timing & Low \\
\hline $\begin{array}{l}\text { Was there an appropriate interval between index test and refer- } \\
\text { ence standard? }\end{array}$ & Yes \\
\hline Did all patients receive the same reference standard? & No \\
\hline Were all patients included in the analysis? & Low \\
\hline
\end{tabular}

Donoso 2004

\section{Study characteristics}

\begin{tabular}{ll}
\hline Patient sampling & Prospective \\
\hline Patient characteristics and setting & $\begin{array}{l}143 \text { children with a first episode of pyelonephritis; unclear } \\
\text { whether elevated CRP/EST or peripheral WBC count was used for } \\
\text { inclusion; unclear whether children were "referred" for DMSA scan } \\
\text { or whether this was per protocol }\end{array}$ \\
\hline Index tests & DMSA \\
\hline Target condition and reference standard(s) & VUR, VCUG \\
\hline Flow and timing & $\begin{array}{l}\text { DMSA was done within 7 days of diagnosis and VCUG unspecified } \\
(69 \% \text { within the first month); 127/143 with complete data }\end{array}$ \\
\hline Comparative & $\begin{array}{l}\text { Authors' judge- } \\
\text { ment }\end{array}$ \\
\hline Notes & Risk of bias \\
\hline Item & Applicability con- \\
\hline
\end{tabular}


Donoso 2004 (Continued)

\section{DOMAIN 1: Patient Selection}

\begin{tabular}{lll}
\hline Was a consecutive or random sample of patients enrolled? & Unclear \\
\hline Was a case-control design avoided? & Yes & Yes \\
\hline Did the study avoid inappropriate exclusions? & & Low Unclear
\end{tabular}

\section{DOMAIN 2: Index Test All tests}

Were the index test results interpreted without knowledge of Yes the results of the reference standard?

If a threshold was used, was it pre-specified?

Yes

Low Low

\section{DOMAIN 3: Reference Standard}

Is the reference standards likely to correctly classify the target Yes condition?

Were the reference standard results interpreted without knowl- Unclear edge of the results of the index tests?

Low Low

\section{DOMAIN 4: Flow and Timing}

Was there an appropriate interval between index test and refer- Unclear ence standard?

Did all patients receive the same reference standard?

Yes

Were all patients included in the analysis?

No

Low

El Shenoufy 2009

\section{Study characteristics}

\begin{tabular}{ll}
\hline Patient sampling & Prospective \\
\hline Patient characteristics and setting & $\begin{array}{l}\text { 45 children aged 1 to 5 years with symptoms of UTI referred to the } \\
\text { "Pediatric Outpatient and Urology clinic at Pediatric Specialized } \\
\text { Hospital" }\end{array}$ \\
\hline Index tests & US \\
\hline Target condition and reference standard(s) & VUR, VCUG \\
\hline
\end{tabular}




\section{El Shenoufy 2009 (Continued)}

Flow and timing

US a week from acute infection and VCUG 4 to 6 weeks after the onset of infection

\section{Comparative}

Notes Threshold for US not clear

\section{Methodological quality}

\begin{tabular}{llll}
\hline Item & $\begin{array}{l}\text { Authors' judge- } \\
\text { ment }\end{array}$ & Risk of bias & $\begin{array}{l}\text { Applicability con- } \\
\text { cerns }\end{array}$ \\
\hline
\end{tabular}

\section{DOMAIN 1: Patient Selection}

\begin{tabular}{llll}
\hline Was a consecutive or random sample of patients enrolled? & Yes \\
\hline Was a case-control design avoided? & Yes & \\
\hline Did the study avoid inappropriate exclusions? & Yes & Low & High
\end{tabular}

\section{DOMAIN 2: Index Test All tests}

Were the index test results interpreted without knowledge of Yes the results of the reference standard?

\begin{tabular}{lll}
\hline If a threshold was used, was it pre-specified? & Yes & Low \\
\hline
\end{tabular}

\section{DOMAIN 3: Reference Standard}

Is the reference standards likely to correctly classify the target Yes condition?

Were the reference standard results interpreted without knowl- Unclear edge of the results of the index tests?

\begin{tabular}{lll}
\hline DOMAIN 4: Flow and Timing & Low \\
\hline $\begin{array}{l}\text { Was there an appropriate interval between index test and refer- } \\
\text { ence standard? }\end{array}$ & Yes \\
\hline Did all patients receive the same reference standard? & Yes \\
\hline Were all patients included in the analysis? & & Low \\
\hline
\end{tabular}


Fernandez-Menendez 2003

\section{Study characteristics}

\begin{tabular}{|c|c|c|c|}
\hline Patient sampling & \multicolumn{3}{|l|}{ Prospective } \\
\hline Patient characteristics and setting & \multicolumn{3}{|c|}{$\begin{array}{l}158 \text { children aged } 1 \text { month to } 14 \text { years with a first episode of symp- } \\
\text { tomatic UTI }(85 \%<2 \text { years); patients attended the emergency } \\
\text { room and were then admitted to the hospital; all but } 5 \text { had fever }\end{array}$} \\
\hline Index tests & \multicolumn{3}{|l|}{ DMSA } \\
\hline Target condition and reference standard(s) & \multicolumn{3}{|l|}{ VUR, VCUG } \\
\hline Flow and timing & \multicolumn{3}{|c|}{$\begin{array}{l}\text { DMSA within } 10 \text { days, VCUG within } 4 \text { weeks after diagnosis; } \\
\text { 150/158 with complete data }\end{array}$} \\
\hline \multicolumn{4}{|l|}{ Comparative } \\
\hline Notes & \multicolumn{3}{|c|}{ Data in terms of renal units, older age not typical } \\
\hline \multicolumn{4}{|l|}{ Methodological quality } \\
\hline Item & $\begin{array}{l}\text { Authors' judge- } \\
\text { ment }\end{array}$ & Risk of bias & $\begin{array}{l}\text { Applicability con- } \\
\text { cerns }\end{array}$ \\
\hline \multicolumn{4}{|l|}{ DOMAIN 1: Patient Selection } \\
\hline Was a consecutive or random sample of patients enrolled? & Yes & & \\
\hline Was a case-control design avoided? & Yes & & \\
\hline \multirow[t]{2}{*}{ Did the study avoid inappropriate exclusions? } & Yes & & \\
\hline & & Low & Low \\
\hline
\end{tabular}

\section{DOMAIN 2: Index Test All tests}

Were the index test results interpreted without knowledge of Yes the results of the reference standard?

If a threshold was used, was it pre-specified? Unclear

\begin{tabular}{lll}
\hline Low & Low \\
\hline DOMAIN 3: Reference Standard & \\
\hline $\begin{array}{l}\text { Is the reference standards likely to correctly classify the target } \quad \text { Yes } \\
\text { condition? }\end{array}$ & Low \\
\hline $\begin{array}{l}\text { Were the reference standard results interpreted without knowl- } \quad \text { Unclear } \\
\text { edge of the results of the index tests? }\end{array}$
\end{tabular}

DOMAIN 4: Flow and Timing 


\section{Fernandez-Menendez 2003 (Continued)}

Was there an appropriate interval between index test and refer- Yes ence standard?

Did all patients receive the same reference standard?

Yes

Were all patients included in the analysis?

No

Low

Goldman 2000

\section{Study characteristics}

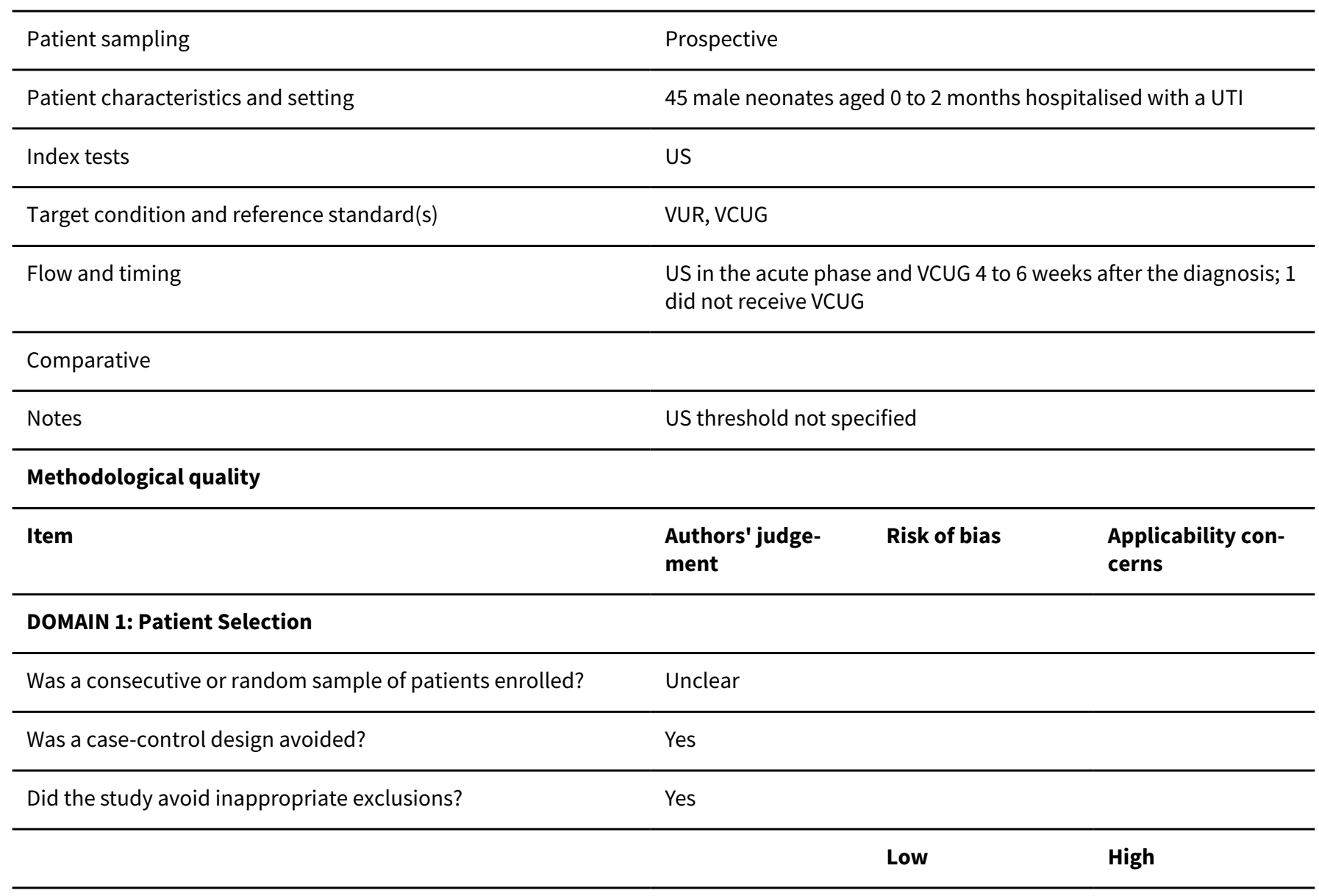

\section{DOMAIN 2: Index Test All tests}

Were the index test results interpreted without knowledge of the results of the reference standard?

If a threshold was used, was it pre-specified?
Yes

Yes

\begin{tabular}{lll}
\hline Low & Low \\
\hline
\end{tabular}

\section{DOMAIN 3: Reference Standard}




\section{Goldman 2000 (Continued)}

Is the reference standards likely to correctly classify the target Yes condition?

Were the reference standard results interpreted without knowl- Unclear edge of the results of the index tests?

Low

Low

\section{DOMAIN 4: Flow and Timing}

Was there an appropriate interval between index test and refer- Yes ence standard?

Did all patients receive the same reference standard? Yes

Were all patients included in the analysis? No

Low

Hoberman 2003

\section{Study characteristics}

\begin{tabular}{|c|c|c|c|}
\hline Patient sampling & \multicolumn{3}{|l|}{ Prospective } \\
\hline Patient characteristics and setting & \multicolumn{3}{|c|}{309 children aged 1 to 24 months admitted with first febrile UTI } \\
\hline Index tests & \multicolumn{3}{|l|}{ US and DMSA } \\
\hline Target condition and reference standard(s) & \multicolumn{3}{|l|}{ VUR, VCUG } \\
\hline Flow and timing & \multicolumn{3}{|c|}{$\begin{array}{l}\text { US within } 48 \text { hours of diagnosis, DMSA within } 48 \text { hours of diagno- } \\
\text { sis in all and VCUG } 1 \text { month after diagnosis in } 302 / 309\end{array}$} \\
\hline \multicolumn{4}{|l|}{ Comparative } \\
\hline Notes & \multicolumn{3}{|c|}{$\begin{array}{l}5 \text { children with abnormal ultrasound but no dilation not included } \\
\text { in the analysis for US (i.e., threshold for US was dilation) }\end{array}$} \\
\hline \multicolumn{4}{|l|}{ Methodological quality } \\
\hline Item & $\begin{array}{l}\text { Authors' judge- } \\
\text { ment }\end{array}$ & Risk of bias & $\begin{array}{l}\text { Applicability con- } \\
\text { cerns }\end{array}$ \\
\hline \multicolumn{4}{|l|}{ DOMAIN 1: Patient Selection } \\
\hline Was a consecutive or random sample of patients enrolled? & Unclear & & \\
\hline Was a case-control design avoided? & Yes & & \\
\hline \multirow[t]{2}{*}{ Did the study avoid inappropriate exclusions? } & Yes & & \\
\hline & & Low & Low \\
\hline
\end{tabular}


Hoberman 2003 (Continued)

\section{DOMAIN 2: Index Test All tests}

Were the index test results interpreted without knowledge of Yes the results of the reference standard?

If a threshold was used, was it pre-specified?

Yes

\begin{tabular}{|c|c|c|}
\hline & Low & Low \\
\hline \multicolumn{3}{|l|}{ DOMAIN 3: Reference Standard } \\
\hline $\begin{array}{l}\text { Is the reference standards likely to correctly classify the target } \\
\text { condition? }\end{array}$ & Yes & \\
\hline \multirow[t]{2}{*}{$\begin{array}{l}\text { Were the reference standard results interpreted without knowl- } \\
\text { edge of the results of the index tests? }\end{array}$} & Yes & \\
\hline & Low & Low \\
\hline \multicolumn{3}{|l|}{ DOMAIN 4: Flow and Timing } \\
\hline $\begin{array}{l}\text { Was there an appropriate interval between index test and refer- } \\
\text { ence standard? }\end{array}$ & Yes & \\
\hline Did all patients receive the same reference standard? & Yes & \\
\hline \multirow[t]{2}{*}{ Were all patients included in the analysis? } & No & \\
\hline & Low & \\
\hline
\end{tabular}

Ilyas 2002

\section{Study characteristics}

\begin{tabular}{ll}
\hline Patient sampling & $\begin{array}{l}\text { Retrospective study of patients with complete radiological evalua- } \\
\text { tion }\end{array}$ \\
\hline Patient characteristics and setting & $\begin{array}{l}222 \text { children aged } 2 \text { months to } 19 \text { years old admitted to hospital } \\
\text { with UTI }\end{array}$ \\
\hline Index tests & DMSA \\
\hline Target condition and reference standard(s) & VUR, VCUG \\
\hline Flow and timing & $\begin{array}{l}\text { DMSA within } 48 \text { hours of admission and VCUG within } 6 \text { weeks of di- } \\
\text { agnosis; } 14 / 222 \text { patients don't have VCUG data }\end{array}$ \\
\hline Comparative & \\
\hline Notes & SPECT DMSA used
\end{tabular}

\section{Methodological quality}


Ilyas 2002 (Continued)

$\begin{array}{llll}\text { Item } & \begin{array}{l}\text { Authors' judge- } \\ \text { ment }\end{array} & \text { Risk of bias } & \begin{array}{l}\text { Applicability con- } \\ \text { cerns }\end{array}\end{array}$

DOMAIN 1: Patient Selection

Was a consecutive or random sample of patients enrolled?

\begin{tabular}{ll}
\hline Was a case-control design avoided? & Yes \\
\hline Did the study avoid inappropriate exclusions? & Yes \\
\hline
\end{tabular}

\begin{tabular}{lcc}
\hline Low & High & Low 2: Index Test All tests \\
\hline Were the index test results interpreted without knowledge of & Yes \\
the results of the reference standard? & Yes & Low \\
\hline If a threshold was used, was it pre-specified? & Low
\end{tabular}

\section{DOMAIN 3: Reference Standard}

Is the reference standards likely to correctly classify the target Yes condition?

Were the reference standard results interpreted without knowl- Unclear edge of the results of the index tests?

Low

Low

\section{DOMAIN 4: Flow and Timing}

Was there an appropriate interval between index test and refer- Yes ence standard?

Did all patients receive the same reference standard?

Yes

Were all patients included in the analysis?

No

\section{Ismaili 2011}

\section{Study characteristics}

\begin{tabular}{ll}
\hline Patient sampling & Prospective \\
\hline Patient characteristics and setting & $\begin{array}{l}209 \text { children aged } 0.2 \text { to } 204 \text { months with first febrile UTI and in- } \\
\text { creased CRP and/or ESR evaluated at the emergency department; } \\
\text { did not exclude patients with known renal or genitourinary abnor- } \\
\text { malities }\end{array}$ \\
\hline
\end{tabular}


Ismaili 2011 (Continued)

Index tests US

Target condition and reference standard(s)

VUR, VCUG

Flow and timing

US within 48 hours of diagnosis and VCUG at least 1 month after UTI

\section{Comparative}

\section{Notes}

\section{Methodological quality}

\begin{tabular}{llll}
\hline Item & $\begin{array}{l}\text { Authors' judge- } \\
\text { ment }\end{array}$ & Risk of bias & $\begin{array}{l}\text { Applicability con- } \\
\text { cerns }\end{array}$ \\
\hline
\end{tabular}

\section{DOMAIN 1: Patient Selection}

\begin{tabular}{ll}
\hline Was a consecutive or random sample of patients enrolled? & Yes \\
\hline Was a case-control design avoided? & Yes \\
\hline
\end{tabular}

Did the study avoid inappropriate exclusions?

Low High

\section{DOMAIN 2: Index Test All tests}

Were the index test results interpreted without knowledge of Yes the results of the reference standard?

\begin{tabular}{lcc}
\hline If a threshold was used, was it pre-specified? & Yes & \\
\hline Low & Low \\
\hline
\end{tabular}

\section{DOMAIN 3: Reference Standard}

Is the reference standards likely to correctly classify the target Yes condition?

Were the reference standard results interpreted without knowl- Unclear edge of the results of the index tests?

\begin{tabular}{llll}
\hline Low & Low \\
\hline
\end{tabular}

\section{DOMAIN 4: Flow and Timing}

Was there an appropriate interval between index test and refer- Unclear ence standard?

Did all patients receive the same reference standard?

Were all patients included in the analysis?
Yes

Yes

Low 
Jakobsson 1992

\section{Study characteristics}

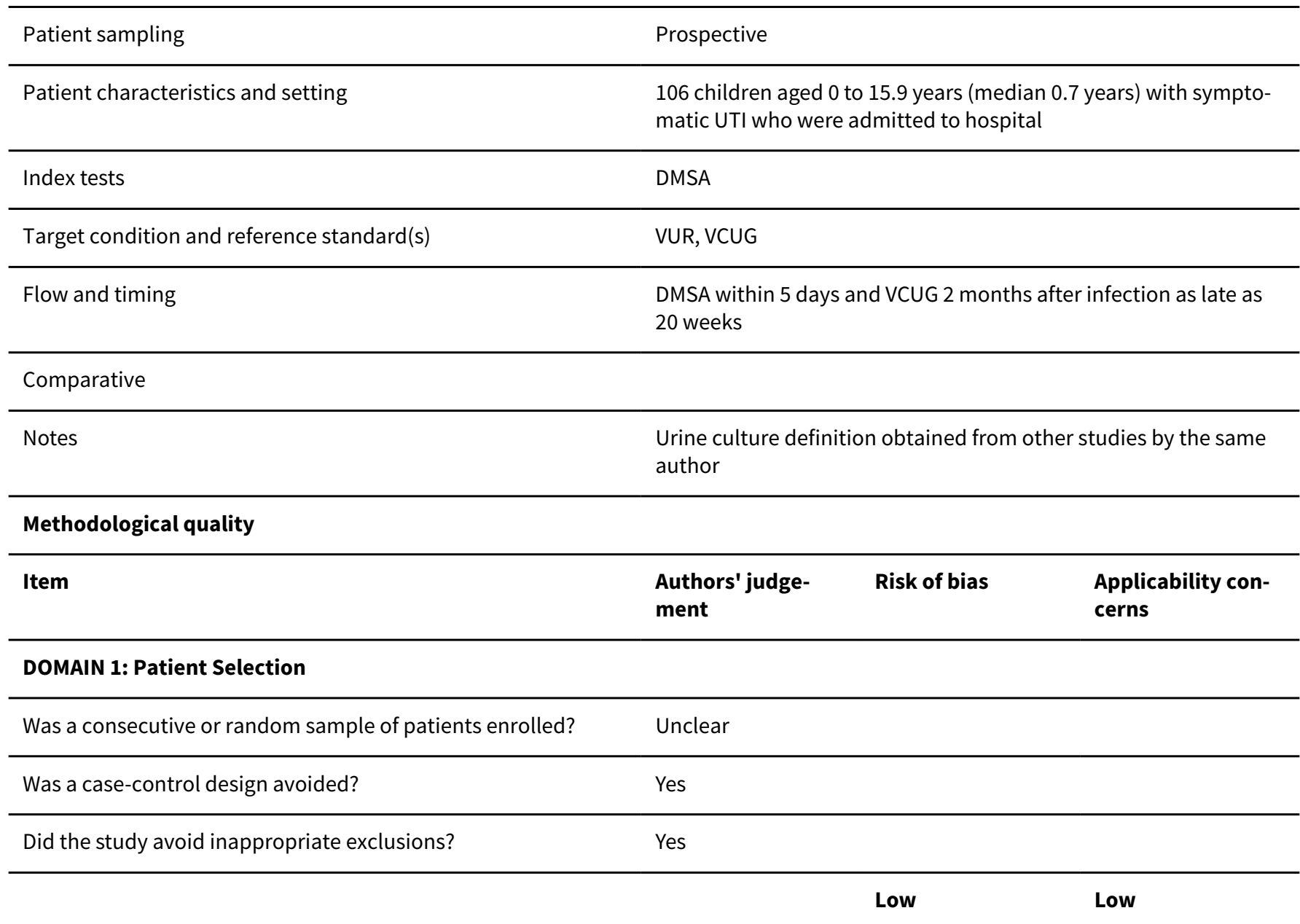

\section{DOMAIN 2: Index Test All tests}

Were the index test results interpreted without knowledge of Yes the results of the reference standard?

\begin{tabular}{lll}
\hline Low & Low \\
\hline
\end{tabular}

\section{DOMAIN 3: Reference Standard}

Is the reference standards likely to correctly classify the target Yes condition?

Were the reference standard results interpreted without knowl- Unclear edge of the results of the index tests?

Low Low

\section{DOMAIN 4: Flow and Timing}


Jakobsson 1992 (Continued)

Was there an appropriate interval between index test and refer- Yes ence standard?

Did all patients receive the same reference standard?

Yes

Were all patients included in the analysis?

Yes

Low

Kim 2006

\section{Study characteristics}

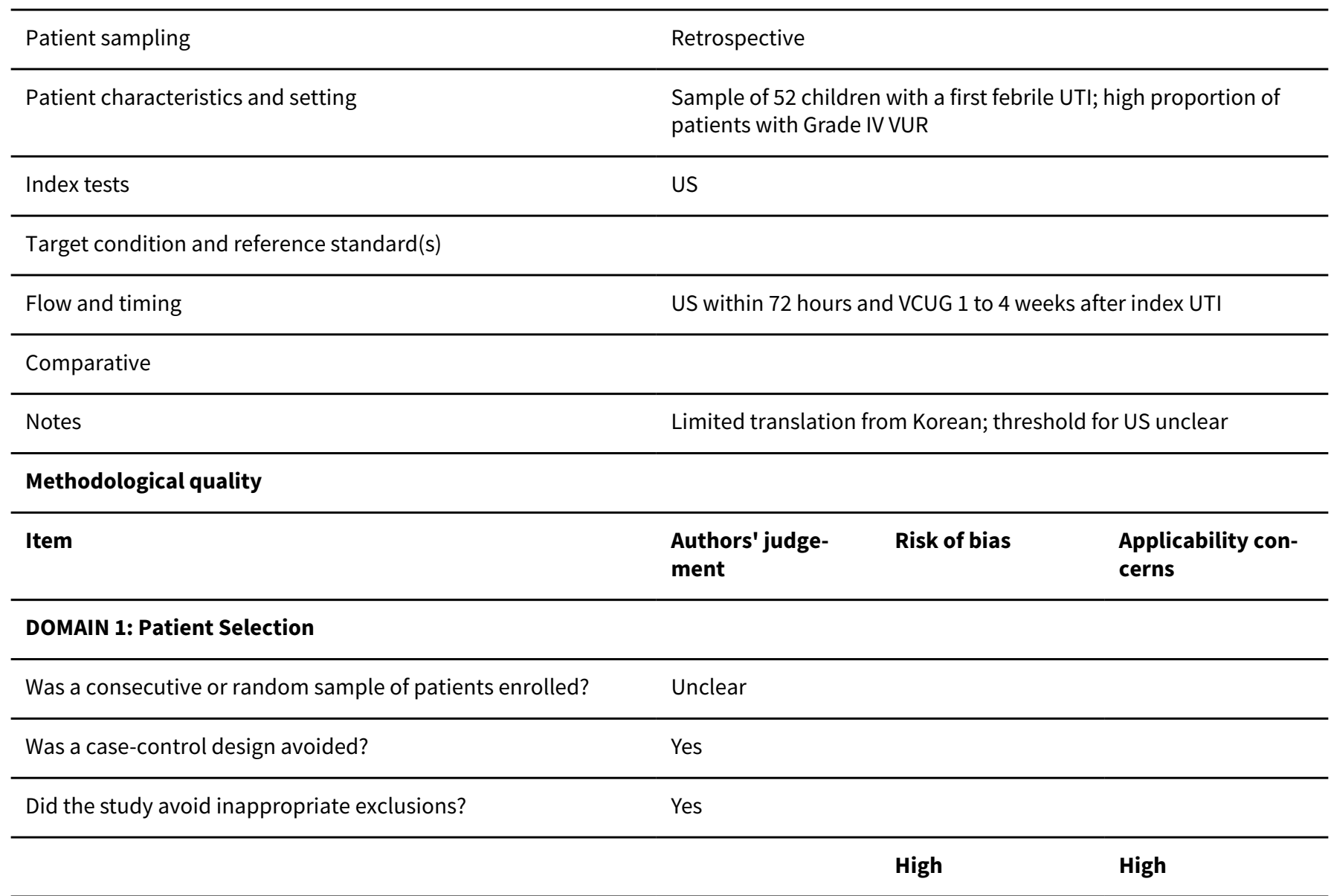

\section{DOMAIN 2: Index Test All tests}

Were the index test results interpreted without knowledge of

the results of the reference standard?

If a threshold was used, was it pre-specified?

Unclear

\begin{tabular}{lll}
\hline Low & Low \\
\hline
\end{tabular}

DOMAIN 3: Reference Standard 
Kim 2006 (Continued)

Is the reference standards likely to correctly classify the target Yes condition?

Were the reference standard results interpreted without knowl- Unclear edge of the results of the index tests?

Low

Low

\section{DOMAIN 4: Flow and Timing}

Was there an appropriate interval between index test and refer- Yes ence standard?

\begin{tabular}{lc}
\hline Did all patients receive the same reference standard? & Yes \\
\hline Were all patients included in the analysis? & Yes \\
\hline & Low \\
\hline
\end{tabular}

\section{Lavocat 1997}

\section{Study characteristics}

\begin{tabular}{ll}
\hline Patient sampling & Prospective \\
\hline Patient characteristics and setting & $\begin{array}{l}55 \mathrm{children} \text { aged } 15 \text { days to 15.5 years admitted for first UTI with a } \\
\mathrm{CRP}>20 \mathrm{mg} / \mathrm{L}\end{array}$ \\
\hline Index tests & DMSA \\
\hline Target condition and reference standard(s) & VUR, VCUG \\
\hline Flow and timing & DMSA within 2 weeks; VCUG a minimum of 3 weeks after onset of \\
& UTI
\end{tabular}

\section{Comparative}

\begin{tabular}{ll}
\hline Notes & $\begin{array}{l}\text { Data in terms of renal units, } 3 \text { patients with change in renal con- } \\
\text { tour or small renal volume on DMSA not counted as abnormal }\end{array}$
\end{tabular}

\section{Methodological quality}

\begin{tabular}{|c|c|c|c|}
\hline Item & $\begin{array}{l}\text { Authors' judge- } \\
\text { ment }\end{array}$ & Risk of bias & $\begin{array}{l}\text { Applicability con- } \\
\text { cerns }\end{array}$ \\
\hline
\end{tabular}

\section{DOMAIN 1: Patient Selection}

\begin{tabular}{lll}
\hline Was a consecutive or random sample of patients enrolled? & Yes \\
\hline Was a case-control design avoided? & Yes & \\
\hline Did the study avoid inappropriate exclusions? & Yes & Low \\
\hline
\end{tabular}


Lavocat 1997 (Continued)

\section{DOMAIN 2: Index Test All tests}

Were the index test results interpreted without knowledge of Yes the results of the reference standard?

If a threshold was used, was it pre-specified?

Yes

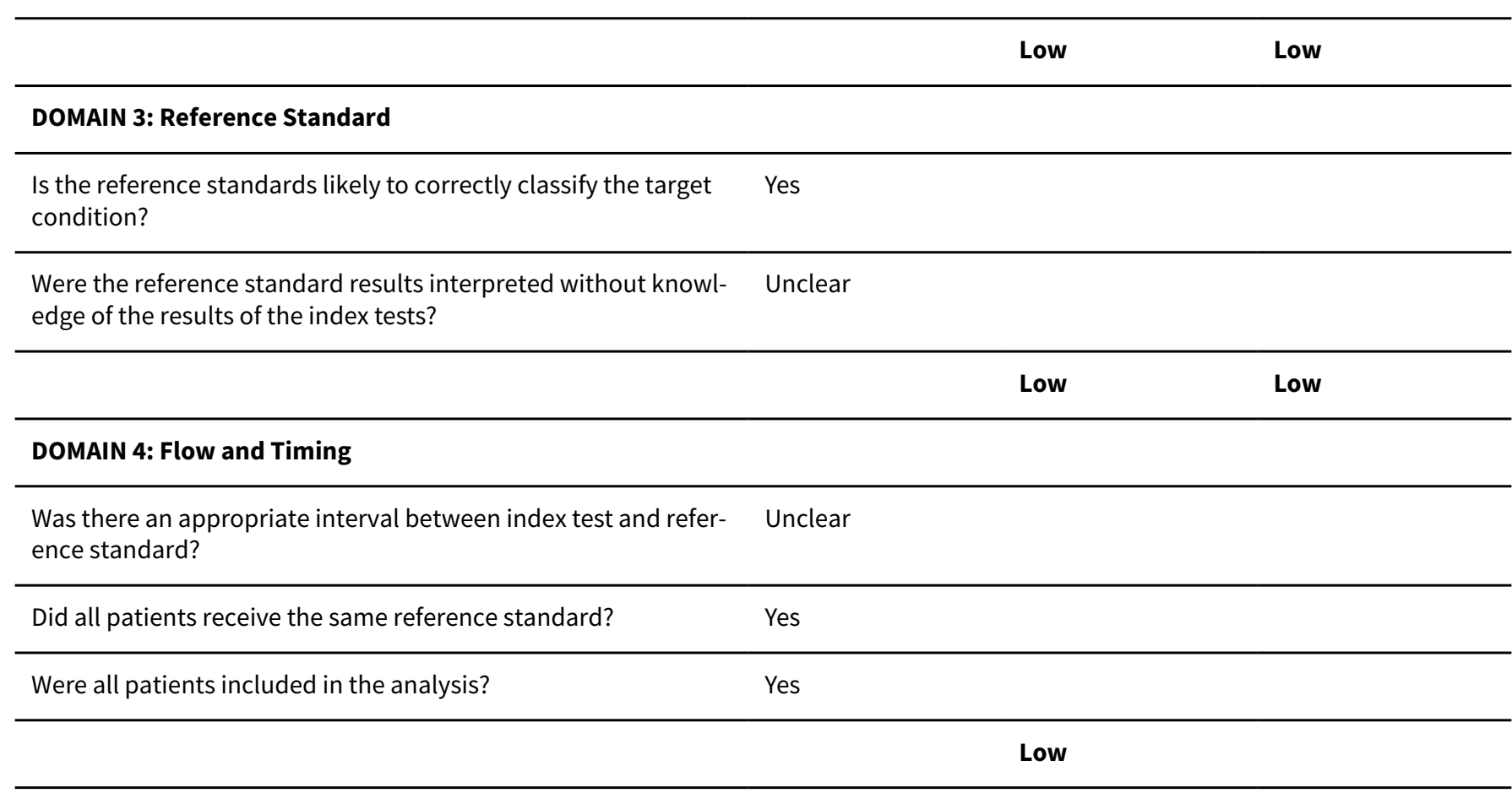

\section{Lee 2009a}

\section{Study characteristics}

\begin{tabular}{ll}
\hline Patient sampling & $\begin{array}{l}\text { Retrospective; appears that only patients with complete imaging } \\
\text { evaluation were included }\end{array}$ \\
\hline Patient characteristics and setting & $\begin{array}{l}220 \text { children aged } 0 \text { to } 2 \text { years with first febrile UTI; setting not } \\
\text { specified; males > females }\end{array}$ \\
\hline Index tests & US and DMSA \\
\hline Target condition and reference standard(s) & $\begin{array}{l}\text { VUR, VCUG; DMSA threshold unusual: > 1 area of photopenia (in- } \\
\text { stead of } \geq 1)\end{array}$ \\
\hline Flow and timing & $\begin{array}{l}\text { US immediately after diagnosis, DMSA/VCUG after resolution of } \\
\text { fever and confirmation of culture results }\end{array}$
\end{tabular}

Comparative

Notes

\section{Methodological quality}


Lee 2009a (Continued)

$\begin{array}{llll}\text { Item } & \begin{array}{l}\text { Authors'judge- } \\ \text { ment }\end{array} & \text { Risk of bias } & \begin{array}{l}\text { Applicability con- } \\ \text { cerns }\end{array}\end{array}$

DOMAIN 1: Patient Selection

\begin{tabular}{ll}
\hline Was a consecutive or random sample of patients enrolled? & Unclear \\
\hline Was a case-control design avoided? & Yes \\
\hline Did the study avoid inappropriate exclusions? & Yes
\end{tabular}

\begin{tabular}{lcc}
\hline & High & Low \\
\hline DOMAIN 2: Index Test Ultrasound & \\
\hline
\end{tabular}

Were the index test results interpreted without knowledge of Yes the results of the reference standard?

If a threshold was used, was it pre-specified?

Yes

Low Low

\section{DOMAIN 2: Index Test DMSA}

Were the index test results interpreted without knowledge of Unclear the results of the reference standard?

\begin{tabular}{llll}
\hline If a threshold was used, was it pre-specified? & Yes & \\
\hline & High & High \\
\hline
\end{tabular}

\section{DOMAIN 3: Reference Standard}

Is the reference standards likely to correctly classify the target Yes condition?

Were the reference standard results interpreted without knowl- Unclear edge of the results of the index tests?

\section{DOMAIN 4: Flow and Timing}

Was there an appropriate interval between index test and refer- Yes ence standard?

Did all patients receive the same reference standard? Yes

Were all patients included in the analysis? Yes


Lee 2012a

\section{Study characteristics}

Patient sampling

Retrospective study of patients with complete radiological evaluation

Patient characteristics and setting

618 children aged 0 to 12 years old admitted to the hospital with first febrile UTI and CRP $>0.3 \mathrm{mg} / \mathrm{dL}$

\begin{tabular}{ll}
\hline Index tests & US and DMSA \\
\hline Target condition and reference standard(s) & VUR, VCUG \\
\hline Flow and timing & $\begin{array}{l}\text { US/DMSA within } 4 \text { days of admission, VCUG within 2 weeks of reso- } \\
\text { lution of fever }\end{array}$ \\
\hline
\end{tabular}

Comparative

$$
\text { Notes }
$$

\section{Methodological quality}

\begin{tabular}{|c|c|c|c|}
\hline Item & $\begin{array}{l}\text { Authors' judge- } \\
\text { ment }\end{array}$ & Risk of bias & $\begin{array}{l}\text { Applicability con- } \\
\text { cerns }\end{array}$ \\
\hline
\end{tabular}

\section{DOMAIN 1: Patient Selection}

\begin{tabular}{llll}
\hline Was a consecutive or random sample of patients enrolled? & No \\
\hline Was a case-control design avoided? & Yes & \\
\hline Did the study avoid inappropriate exclusions? & Yes & High & High
\end{tabular}

\section{DOMAIN 2: Index Test All tests}

Were the index test results interpreted without knowledge of Yes the results of the reference standard?

If a threshold was used, was it pre-specified? Yes

\begin{tabular}{lll}
\hline LOMAIN 3: Reference Standard & Low \\
\hline Is the reference standards likely to correctly classify the target $\quad$ Yes \\
condition?
\end{tabular}

DOMAIN 4: Flow and Timing 
Lee 2012a (Continued)

Was there an appropriate interval between index test and refer- Yes ence standard?

Did all patients receive the same reference standard?

Yes

Were all patients included in the analysis?

Yes

Low

Lin 2007

\section{Study characteristics}

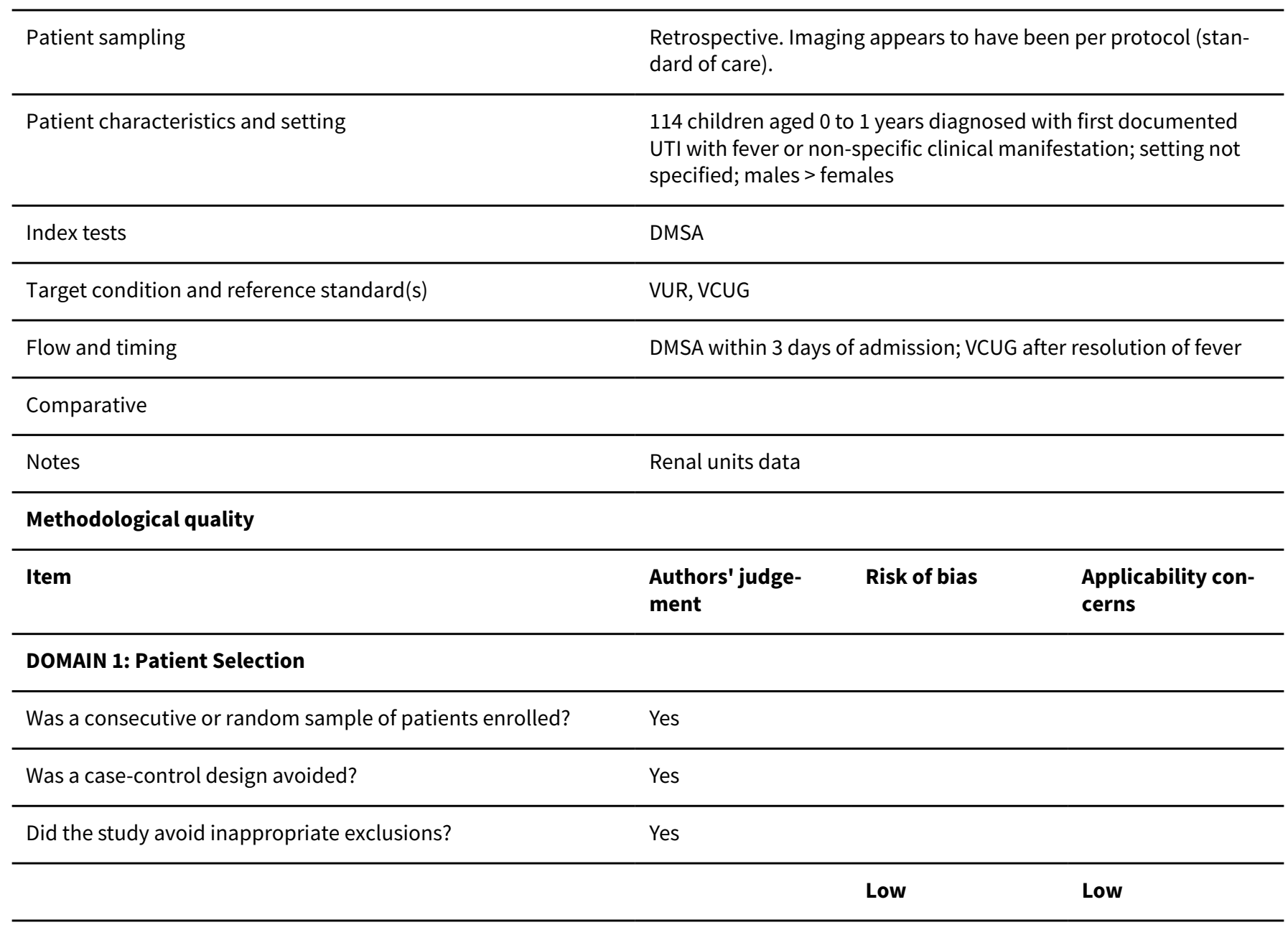

\section{DOMAIN 2: Index Test All tests}

Were the index test results interpreted without knowledge of Yes the results of the reference standard?

If a threshold was used, was it pre-specified? 
Lin 2007 (Continued)

\section{DOMAIN 3: Reference Standard}

Is the reference standards likely to correctly classify the target Yes condition?

Were the reference standard results interpreted without knowl- Unclear edge of the results of the index tests?

Low Low

\section{DOMAIN 4: Flow and Timing}

Was there an appropriate interval between index test and refer- Yes ence standard?

\begin{tabular}{ll}
\hline Did all patients receive the same reference standard? & Yes \\
\hline Were all patients included in the analysis? & Yes \\
\hline
\end{tabular}

Low

Lopez Sastre 2007

\section{Study characteristics}

\begin{tabular}{ll}
\hline Patient sampling & Prospective \\
\hline Patient characteristics and setting & $\begin{array}{l}\text { 301 infants aged 4 to } 40 \text { days old with UTI admitted to acute-care } \\
\text { teaching hospitals }\end{array}$ \\
\hline Index tests & US \\
\hline Target condition and reference standard(s) & $\begin{array}{l}\text { US/VCUG after infectious episode; 291/301 underwent US and } \\
262 / 301 \text { underwent VCUG }\end{array}$ \\
\hline Flow and timing & $\begin{array}{l}\text { Nosocomial UTI in study but we excluded these patients from our } \\
\text { analysis; although threshold for US not clear, most patients had } \\
\text { dilatation }\end{array}$ \\
\hline Comparative & $\begin{array}{l}\text { Authors' judge- } \\
\text { ment }\end{array}$ \\
\hline Notes & Risk of bias
\end{tabular}

\section{DOMAIN 1: Patient Selection}

Was a consecutive or random sample of patients enrolled?

Was a case-control design avoided?

\section{Unclear}

Yes 
Lopez Sastre 2007 (Continued)

\begin{tabular}{lcc}
\hline & Low & High \\
\hline DOMAIN 2: Index Test All tests &
\end{tabular}

\section{DOMAIN 2: Index Test All tests}

Were the index test results interpreted without knowledge of Unclear the results of the reference standard?

\begin{tabular}{|c|c|c|c|}
\hline & & Low & Low \\
\hline \multicolumn{4}{|l|}{ DOMAIN 3: Reference Standard } \\
\hline $\begin{array}{l}\text { Is the reference standards likely to correctly classify the target } \\
\text { condition? }\end{array}$ & Yes & & \\
\hline \multirow[t]{2}{*}{$\begin{array}{l}\text { Were the reference standard results interpreted without knowl- } \\
\text { edge of the results of the index tests? }\end{array}$} & Unclear & & \\
\hline & & Low & Low \\
\hline \multicolumn{4}{|l|}{ DOMAIN 4: Flow and Timing } \\
\hline $\begin{array}{l}\text { Was there an appropriate interval between index test and refer- } \\
\text { ence standard? }\end{array}$ & Unclear & & \\
\hline Did all patients receive the same reference standard? & Yes & & \\
\hline \multirow[t]{2}{*}{ Were all patients included in the analysis? } & No & & \\
\hline & & Low & \\
\hline
\end{tabular}

\section{Mahant 2002}

\section{Study characteristics}

\begin{tabular}{ll}
\hline Patient sampling & Retrospective \\
\hline Patient characteristics and setting & $\begin{array}{l}170 \text { children aged < 5 years with a first UTI who were admitted to } \\
\text { the hospital }\end{array}$ \\
\hline Index tests & US \\
\hline Target condition and reference standard(s) & VUR, VCUG \\
\hline Flow and timing & $\begin{array}{l}\text { US was performed during admission (mean 2 days); unclear timing } \\
\text { for VCUG; VCUG not performed in 8/70 }\end{array}$ \\
\hline Comparative & \\
\hline Notes & \\
\hline
\end{tabular}


Mahant 2002 (Continued)

Methodological quality

\begin{tabular}{llll}
\hline Item & $\begin{array}{l}\text { Authors' judge- } \\
\text { ment }\end{array}$ & Risk of bias & $\begin{array}{l}\text { Applicability con- } \\
\text { cerns }\end{array}$ \\
\hline
\end{tabular}

\section{DOMAIN 1: Patient Selection}

Was a consecutive or random sample of patients enrolled?

Was a case-control design avoided?

Did the study avoid inappropriate exclusions?
Yes

Yes

Yes

Low Low

\section{DOMAIN 2: Index Test All tests}

Were the index test results interpreted without knowledge of Unclear the results of the reference standard?

If a threshold was used, was it pre-specified?

Yes

\begin{tabular}{lll}
\hline LOMAIN 3: Reference Standard & Low & Low \\
\hline $\begin{array}{l}\text { Is the reference standards likely to correctly classify the target } \quad \text { Yes } \\
\text { condition? }\end{array}$ & Low \\
\hline $\begin{array}{l}\text { Were the reference standard results interpreted without knowl- } \quad \text { Unclear } \\
\text { edge of the results of the index tests? }\end{array}$
\end{tabular}

\section{DOMAIN 4: Flow and Timing}

Was there an appropriate interval between index test and refer- Unclear ence standard?

Did all patients receive the same reference standard? Yes

Were all patients included in the analysis? No

\section{Melis 1992}

\section{Study characteristics}

\begin{tabular}{ll}
\hline Patient sampling & Retrospective; imaging was per hospital protocol \\
\hline Patient characteristics and setting & $\begin{array}{l}146 \text { patients }<16 \text { years admitted with a febrile UTI; } 47 \%<2 \text { years; } \\
\text { did not exclude children with previous genitourinary } / \text { renal abnor- } \\
\text { malities }\end{array}$ \\
\end{tabular}


Melis 1992 (Continued)

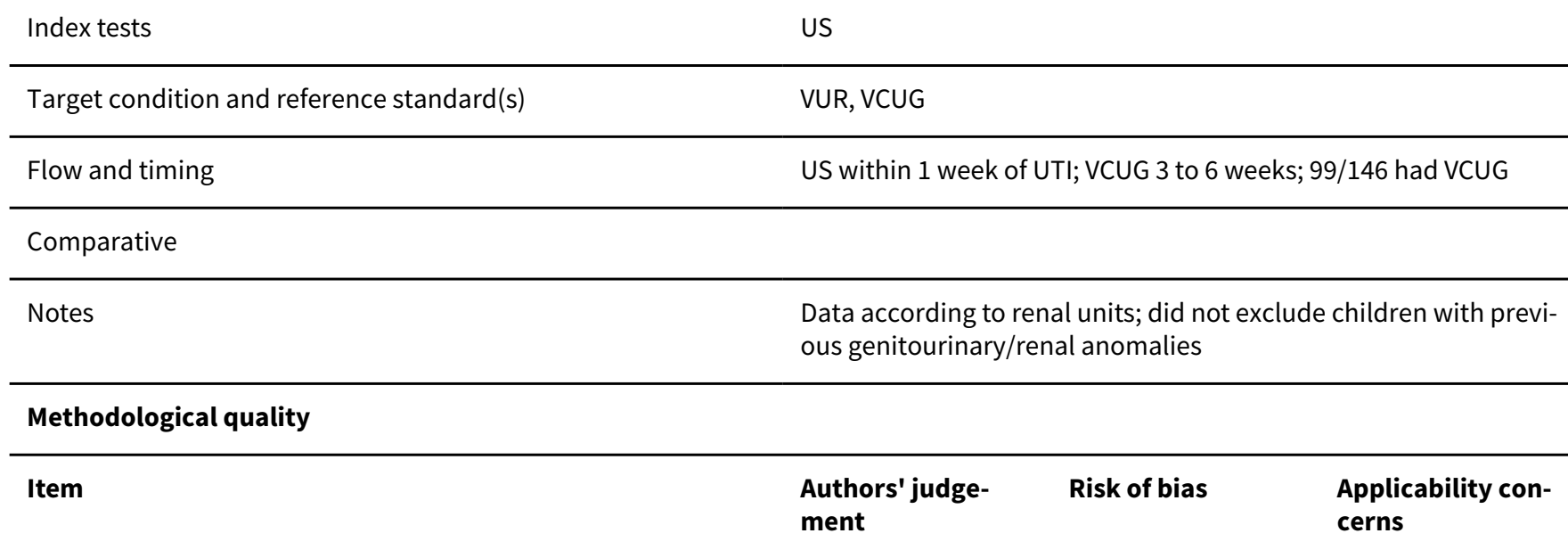

\section{DOMAIN 1: Patient Selection}

\begin{tabular}{llll}
\hline Was a consecutive or random sample of patients enrolled? & Unclear \\
\hline Was a case-control design avoided? & Yes & \\
\hline Did the study avoid inappropriate exclusions? & Yes & Low & High
\end{tabular}

\section{DOMAIN 2: Index Test All tests}

Were the index test results interpreted without knowledge of Yes the results of the reference standard?

\begin{tabular}{lll}
\hline If a threshold was used, was it pre-specified? & Yes & Low \\
\hline
\end{tabular}

\section{DOMAIN 3: Reference Standard}

Is the reference standards likely to correctly classify the target Yes condition?

Were the reference standard results interpreted without knowl- Unclear edge of the results of the index tests?

\begin{tabular}{lll}
\hline & Low & Low \\
\hline DOMAIN 4: Flow and Timing &
\end{tabular}

Was there an appropriate interval between index test and refer- Yes ence standard?

Did all patients receive the same reference standard?

Were all patients included in the analysis?
No

No

High 
Montini 2009

\section{Study characteristics}

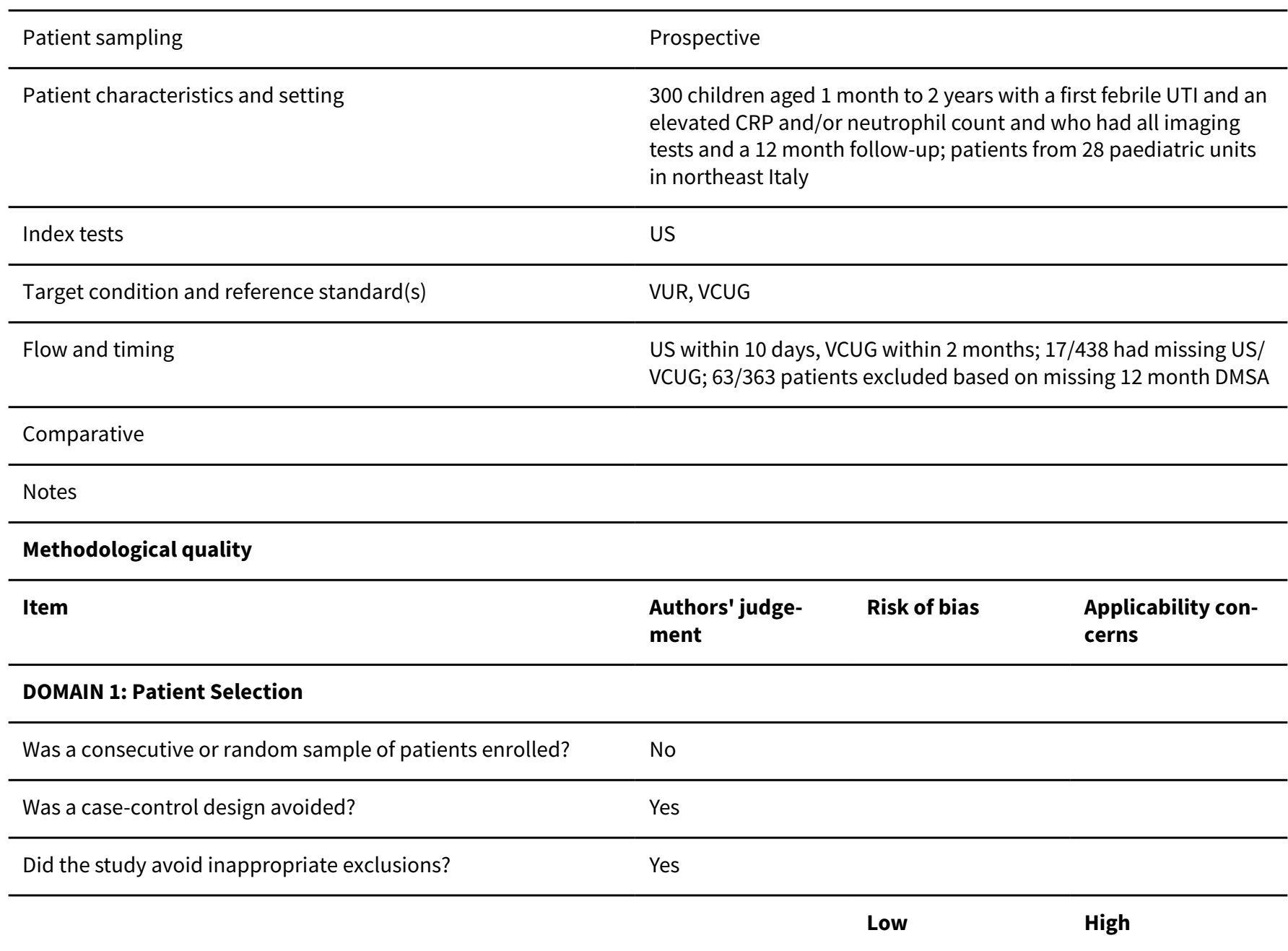

\section{DOMAIN 2: Index Test All tests}

Were the index test results interpreted without knowledge of Yes the results of the reference standard?

If a threshold was used, was it pre-specified? Yes

\begin{tabular}{lll}
\hline LOMAIN 3: Reference Standard & Low & Low \\
\hline Is the reference standards likely to correctly classify the target $\quad$ Yes \\
condition?
\end{tabular}

DOMAIN 4: Flow and Timing

Dimercaptosuccinic acid scan or ultrasound in screening for vesicoureteral reflux among children with urinary tract infections (Review) 


\section{Montini 2009 (Continued)}

Was there an appropriate interval between index test and refer- Yes ence standard?

Did all patients receive the same reference standard?

Yes

Were all patients included in the analysis?

No

Low

\section{Morin 1999}

\section{Study characteristics}

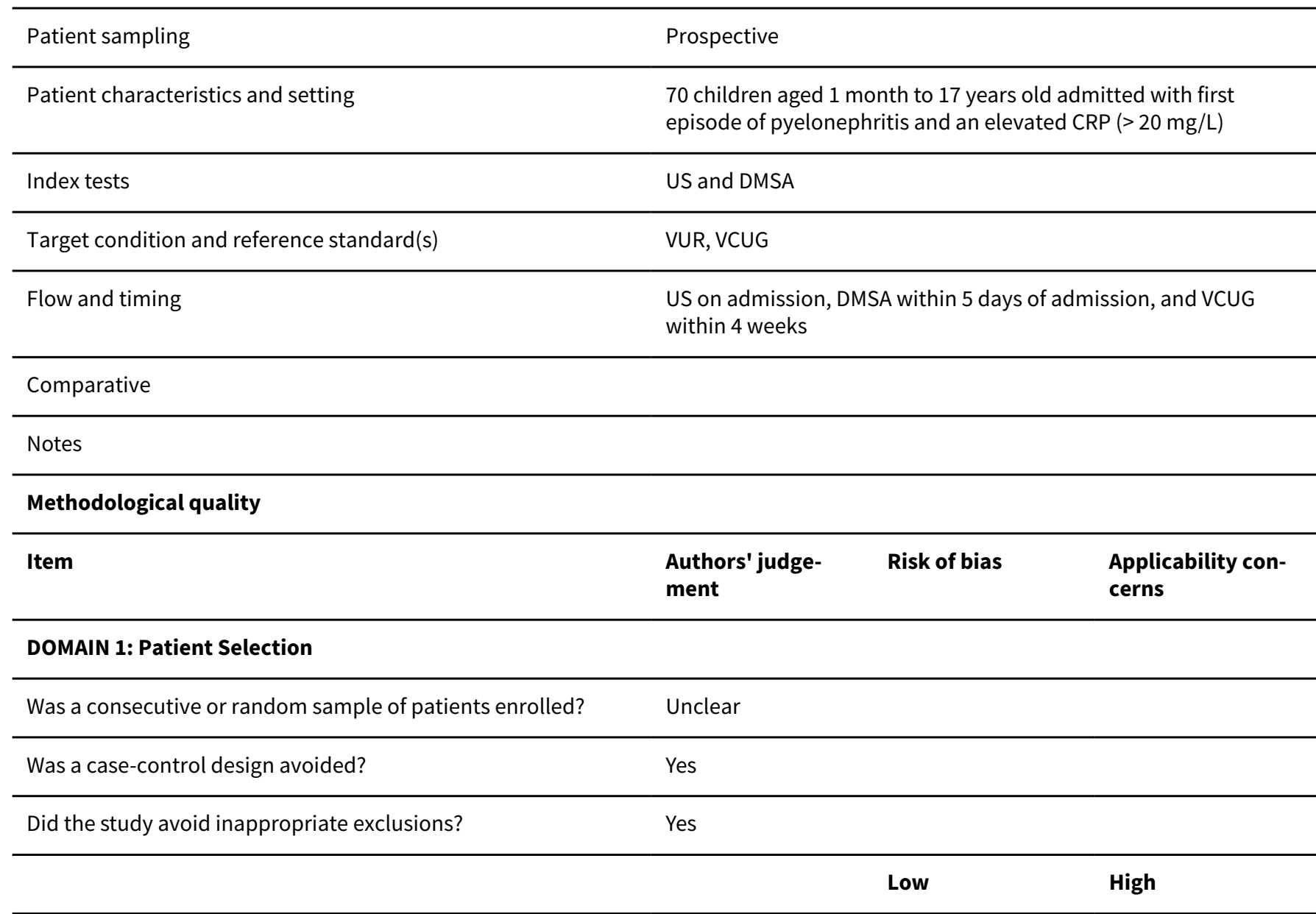

DOMAIN 2: Index Test All tests

Were the index test results interpreted without knowledge of Yes the results of the reference standard?

If a threshold was used, was it pre-specified? Yes

Low Low

\section{DOMAIN 3: Reference Standard}

Dimercaptosuccinic acid scan or ultrasound in screening for vesicoureteral reflux among children with urinary tract infections (Review) 
Morin 1999 (Continued)

Is the reference standards likely to correctly classify the target Yes condition?

Were the reference standard results interpreted without knowl- Unclear edge of the results of the index tests?

\section{Low}

Low

\section{DOMAIN 4: Flow and Timing}

Was there an appropriate interval between index test and refer- Yes ence standard?

\begin{tabular}{ll}
\hline Did all patients receive the same reference standard? Yes & ?
\end{tabular}

Were all patients included in the analysis? Yes

\section{Muller 2009}

\section{Study characteristics}

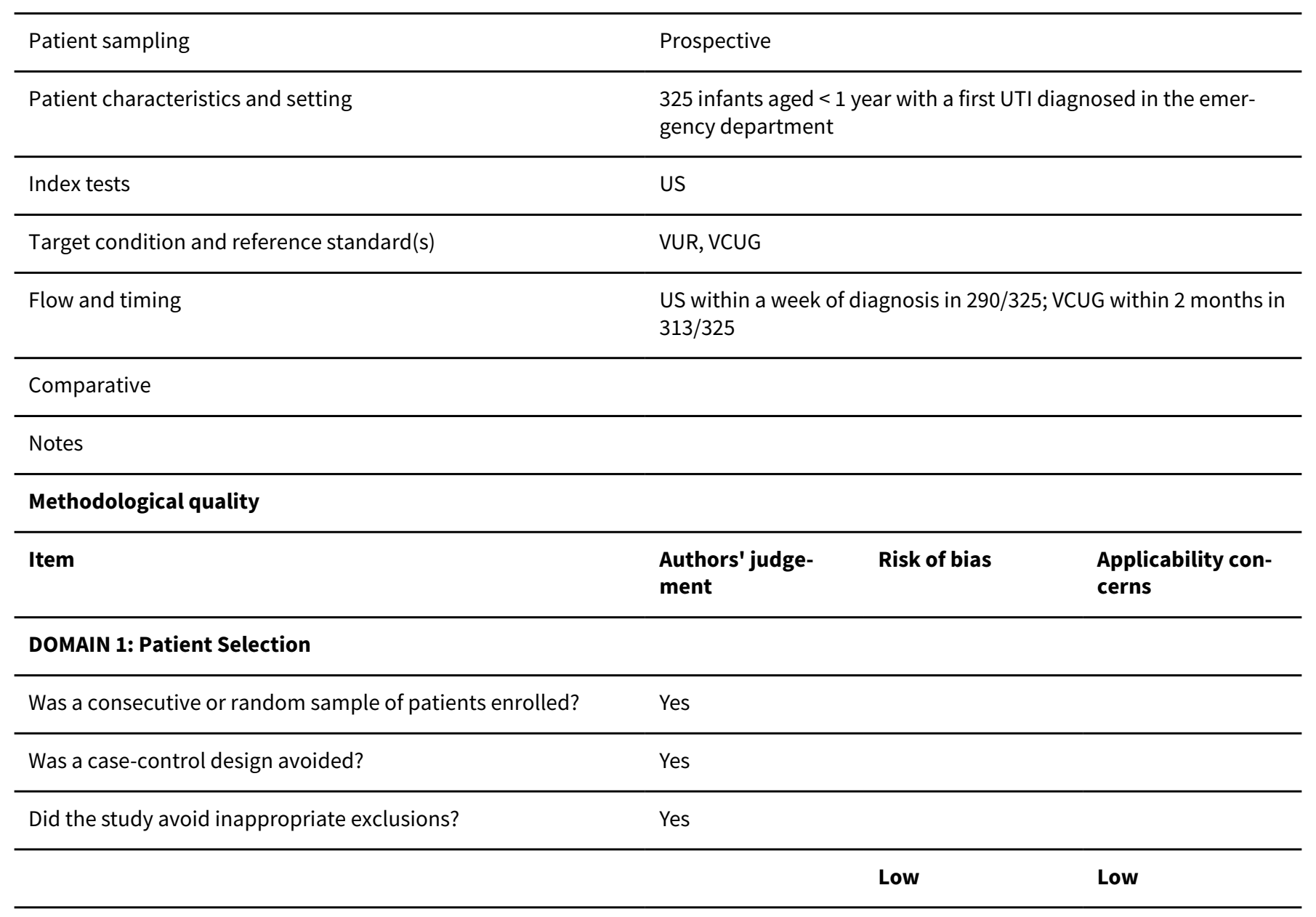


Muller 2009 (Continued)

\section{DOMAIN 2: Index Test All tests}

Were the index test results interpreted without knowledge of Yes the results of the reference standard?

If a threshold was used, was it pre-specified?

Yes

\begin{tabular}{|c|c|c|c|}
\hline & & Low & Low \\
\hline \multicolumn{4}{|l|}{ DOMAIN 3: Reference Standard } \\
\hline $\begin{array}{l}\text { Is the reference standards likely to correctly classify the target } \\
\text { condition? }\end{array}$ & Yes & & \\
\hline \multirow[t]{2}{*}{$\begin{array}{l}\text { Were the reference standard results interpreted without knowl- } \\
\text { edge of the results of the index tests? }\end{array}$} & Unclear & & \\
\hline & & Low & Low \\
\hline \multicolumn{4}{|l|}{ DOMAIN 4: Flow and Timing } \\
\hline $\begin{array}{l}\text { Was there an appropriate interval between index test and refer- } \\
\text { ence standard? }\end{array}$ & Yes & & \\
\hline Did all patients receive the same reference standard? & Yes & & \\
\hline \multirow[t]{2}{*}{ Were all patients included in the analysis? } & No & & \\
\hline & & Low & \\
\hline
\end{tabular}

\section{Oh 2012}

\section{Study characteristics}

\begin{tabular}{ll}
\hline Patient sampling & Prospective \\
\hline Patient characteristics and setting & $\begin{array}{l}230 \text { children admitted first febrile UTI; mean age 9 months; males } \\
\text { f females }\end{array}$ \\
\hline Index tests & DMSA \\
\hline Target condition and reference standard(s) & VUR, VCUG \\
\hline Flow and timing & DMSA within 7 days; VCUG 3 to 6 weeks \\
\hline Comparative & $\begin{array}{l}\text { Authors' judge- } \\
\text { ment }\end{array}$ \\
\hline Notes & Risk of bias \\
\hline Methodological quality & Applicability con- \\
\hline Item & cerns
\end{tabular}


Oh 2012 (Continued)

\section{DOMAIN 1: Patient Selection}

\begin{tabular}{lll}
\hline Was a consecutive or random sample of patients enrolled? & Unclear \\
\hline Was a case-control design avoided? & Yes & Yes \\
\hline Did the study avoid inappropriate exclusions? & Low & Low \\
\hline
\end{tabular}

\section{DOMAIN 2: Index Test All tests}

Were the index test results interpreted without knowledge of Yes the results of the reference standard?

If a threshold was used, was it pre-specified?

Yes

Low Low

\section{DOMAIN 3: Reference Standard}

Is the reference standards likely to correctly classify the target Yes condition?

Were the reference standard results interpreted without knowl- Unclear edge of the results of the index tests?

Low Low

\section{DOMAIN 4: Flow and Timing}

Was there an appropriate interval between index test and refer- Yes ence standard?

Did all patients receive the same reference standard? Yes

Were all patients included in the analysis? Yes

Low

Preda 2007

\section{Study characteristics}

\begin{tabular}{ll}
\hline Patient sampling & Prospective \\
\hline Patient characteristics and setting & $\begin{array}{l}325 \text { infants aged }<1 \text { year with first symptomatic UTI diagnosed in } \\
\text { the emergency department }\end{array}$ \\
\hline Index tests & DMSA \\
\hline Target condition and reference standard(s) & VUR, VCUG \\
\hline
\end{tabular}


Preda 2007 (Continued)

Flow and timing

DMSA < 30 days; VCUG within 2 months; excluded 11 with no VCUG and 24 with missing DMSA or DMSA conducted after 30 days

\section{Comparative}

\section{Notes}

\section{Methodological quality}

\begin{tabular}{llll}
\hline Item & $\begin{array}{l}\text { Authors' judge- } \\
\text { ment }\end{array}$ & Risk of bias & $\begin{array}{l}\text { Applicability con- } \\
\text { cerns }\end{array}$ \\
\hline
\end{tabular}

\section{DOMAIN 1: Patient Selection}

\begin{tabular}{lll}
\hline Was a consecutive or random sample of patients enrolled? & Yes \\
\hline Was a case-control design avoided? & Yes \\
\hline Did the study avoid inappropriate exclusions? & Yes & Low \\
\hline
\end{tabular}

\section{DOMAIN 2: Index Test All tests}

Were the index test results interpreted without knowledge of Unclear the results of the reference standard?

\begin{tabular}{lll}
\hline If a threshold was used, was it pre-specified? & Yes & Low \\
\hline
\end{tabular}

\section{DOMAIN 3: Reference Standard}

Is the reference standards likely to correctly classify the target Yes condition?

Were the reference standard results interpreted without knowl- Unclear edge of the results of the index tests?

Low Low

\section{DOMAIN 4: Flow and Timing}

Was there an appropriate interval between index test and refer- Yes ence standard?

Did all patients receive the same reference standard? Yes

Were all patients included in the analysis?

No 
Sayedzadeh 2011

\section{Study characteristics}

Patient sampling

Patient characteristics and setting

\begin{tabular}{ll}
\hline Index tests DMSA & DM
\end{tabular}

\begin{tabular}{ll}
\hline Target condition and reference standard(s) & VUR, VCUG \\
\hline Flow and timing & $\begin{array}{l}\text { DMSA within 14 days; VCUG after treatment and negative urine } \\
\text { culture }\end{array}$
\end{tabular}

Comparative

$$
\text { Notes }
$$

\section{Methodological quality}

\begin{tabular}{|c|c|c|c|}
\hline Item & $\begin{array}{l}\text { Authors' judge- } \\
\text { ment }\end{array}$ & Risk of bias & $\begin{array}{l}\text { Applicability con- } \\
\text { cerns }\end{array}$ \\
\hline
\end{tabular}

\section{DOMAIN 1: Patient Selection}

\begin{tabular}{llll}
\hline Was a consecutive or random sample of patients enrolled? & Unclear \\
\hline Was a case-control design avoided? & Yes & \\
\hline Did the study avoid inappropriate exclusions? & No & Unclear & High \\
\hline
\end{tabular}

DOMAIN 2: Index Test All tests

Were the index test results interpreted without knowledge of Unclear the results of the reference standard?

If a threshold was used, was it pre-specified? Yes

\begin{tabular}{lll}
\hline LOMAIN 3: Reference Standard & Low \\
\hline $\begin{array}{l}\text { Is the reference standards likely to correctly classify the target } \quad \text { Yes } \\
\text { condition? }\end{array}$ & Low & Low \\
\hline $\begin{array}{l}\text { Were the reference standard results interpreted without knowl- } \\
\text { edge of the results of the index tests? }\end{array}$
\end{tabular}

DOMAIN 4: Flow and Timing 


\section{Sayedzadeh 2011 (Continued)}

Was there an appropriate interval between index test and refer- Yes ence standard?

Did all patients receive the same reference standard?

Yes

Were all patients included in the analysis?

Yes

Low

Sheu 2013

\section{Study characteristics}

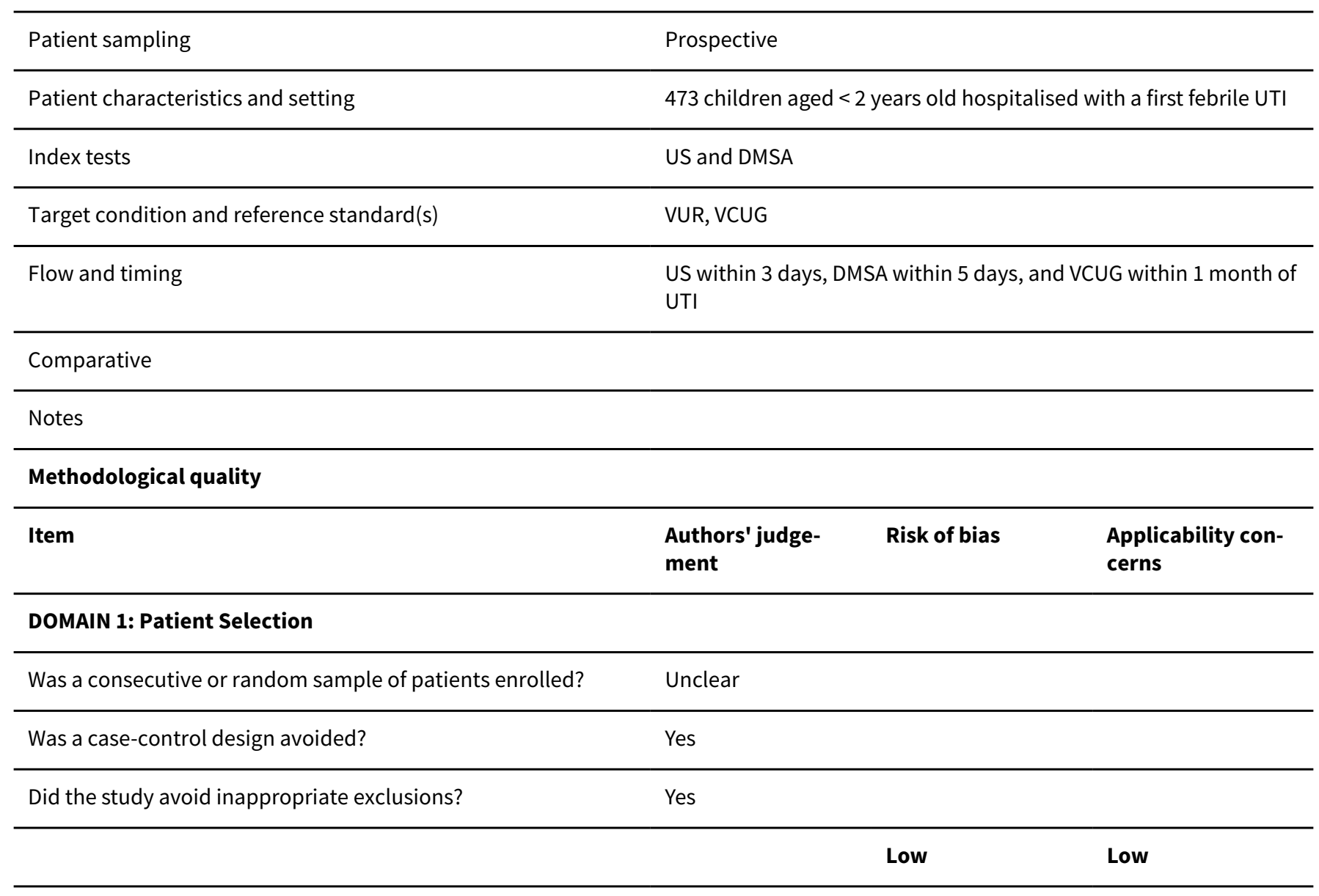

\section{DOMAIN 2: Index Test All tests}

Were the index test results interpreted without knowledge of the results of the reference standard?

If a threshold was used, was it pre-specified?
Yes

Yes

\begin{tabular}{lll}
\hline Low & Low \\
\hline
\end{tabular}

\section{DOMAIN 3: Reference Standard}


Sheu 2013 (Continued)

Is the reference standards likely to correctly classify the target Yes condition?

Were the reference standard results interpreted without knowl- Unclear edge of the results of the index tests?

Low

Low

\section{DOMAIN 4: Flow and Timing}

Was there an appropriate interval between index test and refer- Yes ence standard?

Did all patients receive the same reference standard? Yes

Were all patients included in the analysis? Yes

Low

Sorkhi 2011

\section{Study characteristics}

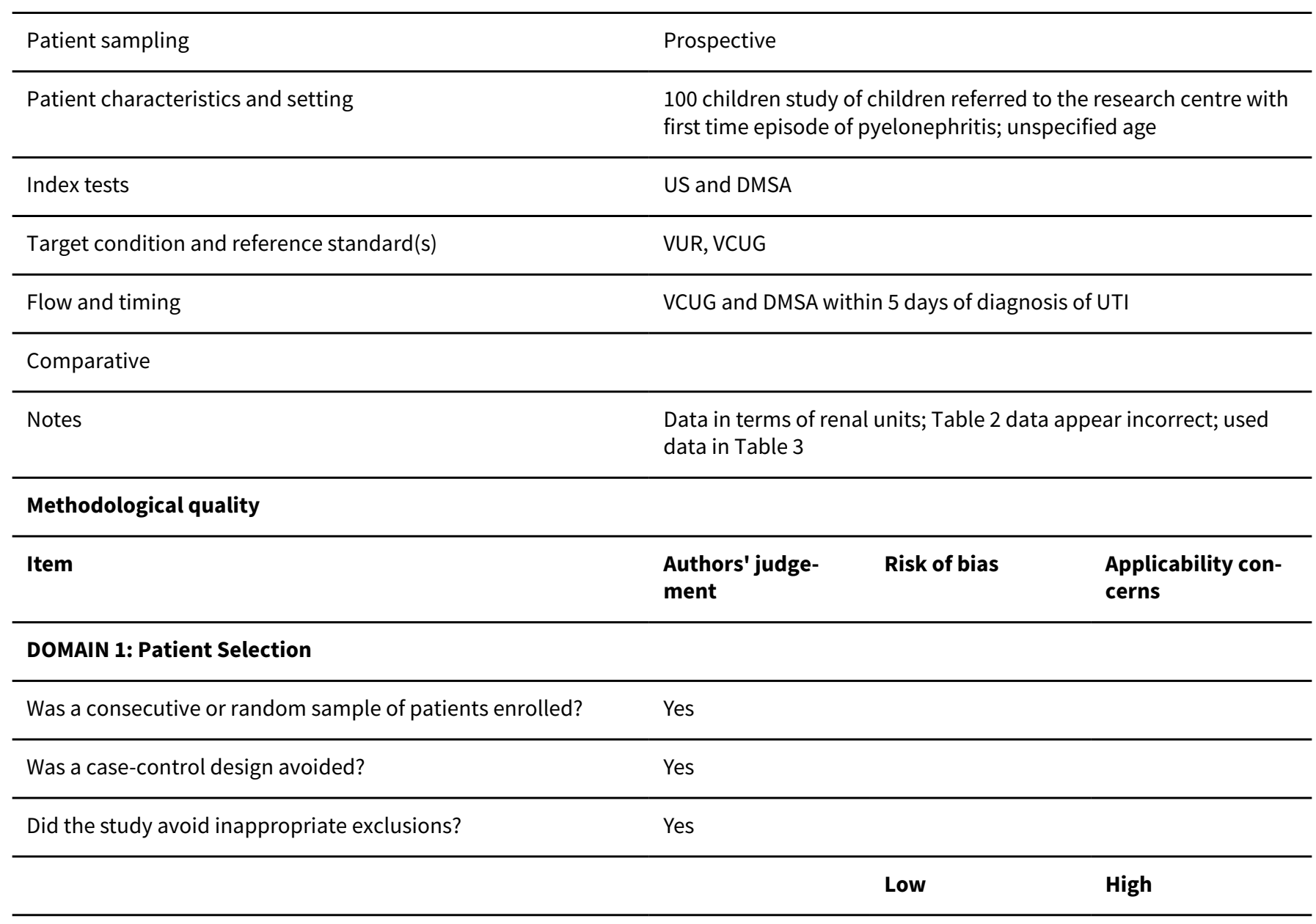


Sorkhi 2011 (Continued)

\section{DOMAIN 2: Index Test All tests}

Were the index test results interpreted without knowledge of Unclear the results of the reference standard?

If a threshold was used, was it pre-specified?

Yes

\begin{tabular}{ll}
\hline & Low \\
\hline DOMAIN 3: Reference Standard & Low \\
\hline $\begin{array}{l}\text { Is the reference standards likely to correctly classify the target } \quad \text { Yes } \\
\text { condition? }\end{array}$ & Low \\
\hline $\begin{array}{l}\text { Were the reference standard results interpreted without knowl- } \\
\text { edge of the results of the index tests? }\end{array}$ & Low \\
\hline DOMAIN 4: Flow and Timing & Yes \\
\hline $\begin{array}{l}\text { Was there an appropriate interval between index test and refer- } \\
\text { ence standard? }\end{array}$ \\
\hline Did all patients receive the same reference standard? & Yes \\
\hline Were all patients included in the analysis? & Low \\
\hline
\end{tabular}

Soylu 2007

\section{Study characteristics}

\begin{tabular}{|c|c|}
\hline Patient sampling & $\begin{array}{l}\text { Retrospective study of patients with complete radiological evalua- } \\
\text { tion }\end{array}$ \\
\hline Patient characteristics and setting & $\begin{array}{l}88 \text { patient aged } 0 \text { to } 204 \text { months with febrile UTI who were re- } \\
\text { ferred to the Paediatric Nephrology Unit }\end{array}$ \\
\hline Index tests & US \\
\hline Target condition and reference standard(s) & VUR, VCUG \\
\hline Flow and timing & Unclear timing for US and VCUG \\
\hline \multicolumn{2}{|l|}{ Comparative } \\
\hline \multicolumn{2}{|l|}{ Notes } \\
\hline \multicolumn{2}{|l|}{ Methodological quality } \\
\hline Item & $\begin{array}{l}\text { Applicability con- } \\
\text { cerns }\end{array}$ \\
\hline
\end{tabular}


Soylu 2007 (Continued)

\section{DOMAIN 1: Patient Selection}

\begin{tabular}{lccc}
\hline Was a consecutive or random sample of patients enrolled? & No & Yes & \\
\hline Was a case-control design avoided? & Yes & High & High \\
\hline Did the study avoid inappropriate exclusions? & Unclear & \\
\hline DomAIN 2: Index Test All tests & Yes & Low \\
\hline Were the index test results interpreted without knowledge of & & Low \\
\hline If a threshold was used, was it pre-specified?
\end{tabular}

\section{DOMAIN 3: Reference Standard}

Is the reference standards likely to correctly classify the target Yes condition?

Were the reference standard results interpreted without knowl- Unclear edge of the results of the index tests?

Low Low

\section{DOMAIN 4: Flow and Timing}

Was there an appropriate interval between index test and refer- Unclear ence standard?

Did all patients receive the same reference standard? Yes

Were all patients included in the analysis? Yes

Low

Supavekin 2013a

\section{Study characteristics}

\begin{tabular}{ll}
\hline Patient sampling & Prospective \\
\hline Patient characteristics and setting & $\begin{array}{l}67 \text { hospitalised children aged 0.02 to 7.26 years hospitalised with } \\
\text { first episode of UTI; mean age of 1 year }\end{array}$ \\
\hline Index tests & US \\
\hline Target condition and reference standard(s) & US timing unclear \\
\hline Flow and timing & \\
\hline & \\
\hline $\begin{array}{l}\text { Dimercaptosuccinic acid scan or ultrasound in screening for vesicoureteral reflux among children with urinary tract infections (Review) } \\
\text { Copyright @ 2016 The Cochrane Collaboration. Published by John Wiley \& Sons, Ltd. }\end{array}$
\end{tabular}

Copyright $\odot 2016$ The Cochrane Collaboration. Published by John Wiley \& Sons, Ltd. 
Supavekin 2013a (Continued)

Comparative

$$
\text { Notes }
$$

\section{Methodological quality}

\begin{tabular}{|c|c|c|c|}
\hline Item & $\begin{array}{l}\text { Authors' judge- } \\
\text { ment }\end{array}$ & Risk of bias & $\begin{array}{l}\text { Applicability con- } \\
\text { cerns }\end{array}$ \\
\hline
\end{tabular}

\section{DOMAIN 1: Patient Selection}

\begin{tabular}{llll}
\hline Was a consecutive or random sample of patients enrolled? & Unclear \\
\hline Was a case-control design avoided? & Yes & \\
\hline Did the study avoid inappropriate exclusions? & Yes & Low & Low \\
\hline
\end{tabular}

DOMAIN 2: Index Test All tests

Were the index test results interpreted without knowledge of Unclear
the results of the reference standard?

\begin{tabular}{|c|c|c|c|}
\hline & & Low & Low \\
\hline \multicolumn{4}{|l|}{ DOMAIN 3: Reference Standard } \\
\hline $\begin{array}{l}\text { Is the reference standards likely to correctly classify the target } \\
\text { condition? }\end{array}$ & Yes & & \\
\hline \multirow[t]{2}{*}{$\begin{array}{l}\text { Were the reference standard results interpreted without knowl- } \\
\text { edge of the results of the index tests? }\end{array}$} & Unclear & & \\
\hline & & Low & Low \\
\hline \multicolumn{4}{|l|}{ DOMAIN 4: Flow and Timing } \\
\hline $\begin{array}{l}\text { Was there an appropriate interval between index test and refer- } \\
\text { ence standard? }\end{array}$ & Yes & & \\
\hline Did all patients receive the same reference standard? & Yes & & \\
\hline \multirow[t]{2}{*}{ Were all patients included in the analysis? } & Yes & & \\
\hline & & Low & \\
\hline
\end{tabular}

\section{Study characteristics}


Tsai 1996 (Continued)

Patient sampling

Patient characteristics and setting

Index tests

Target condition and reference standard(s)

Flow and timing
Retrospective study of patients with complete radiological evaluation

247 children aged $<16$ years admitted to the hospital for UTI

DMSA

VUR, VCUG

DMSA within first 3 days of diagnosis and VCUG 10 to 14 days after treatment; 230/247 had VCUG

Comparative

Notes

Data according to renal units

\section{Methodological quality}

\begin{tabular}{|c|c|c|c|}
\hline Item & $\begin{array}{l}\text { Authors' judge- } \\
\text { ment }\end{array}$ & Risk of bias & $\begin{array}{l}\text { Applicability con- } \\
\text { cerns }\end{array}$ \\
\hline
\end{tabular}

\section{DOMAIN 1: Patient Selection}

\begin{tabular}{llll}
\hline Was a consecutive or random sample of patients enrolled? & Unclear \\
\hline Was a case-control design avoided? & Yes & \\
\hline Did the study avoid inappropriate exclusions? & Yes & High & Low \\
\hline
\end{tabular}

\section{DOMAIN 2: Index Test All tests}

Were the index test results interpreted without knowledge of Yes the results of the reference standard?

If a threshold was used, was it pre-specified?

Yes

\begin{tabular}{lll}
\hline High & Low \\
\hline
\end{tabular}

\section{DOMAIN 3: Reference Standard}

Is the reference standards likely to correctly classify the target Yes condition?

Were the reference standard results interpreted without knowl- Unclear edge of the results of the index tests?

\begin{tabular}{|c|c|c|}
\hline & Low & Low \\
\hline \multicolumn{3}{|l|}{ DOMAIN 4: Flow and Timing } \\
\hline $\begin{array}{l}\text { Was there an appropriate interval between index test and refer- } \\
\text { ence standard? }\end{array}$ & Yes & \\
\hline Did all patients receive the same reference standard? & Yes & \\
\hline
\end{tabular}


Tsai 1996 (Continued)

Tsai 2012

\section{Study characteristics}

\begin{tabular}{|c|c|c|c|}
\hline Patient sampling & \multicolumn{3}{|l|}{ Prospective } \\
\hline Patient characteristics and setting & \multicolumn{3}{|c|}{231 infants aged 0 to 3 months hospitalised with first febrile UTI } \\
\hline Index tests & \multicolumn{3}{|l|}{ US and DMSA } \\
\hline Target condition and reference standard(s) & \multicolumn{3}{|l|}{ VUR, VCUG } \\
\hline Flow and timing & \multicolumn{3}{|c|}{$\begin{array}{l}\text { US within } 3 \text { days and DMSA within } 5 \text { days of diagnosis of UTI; VCUG } \\
7 \text { to } 10 \text { days after end of antibiotic therapy; } 11 / 231 \text { patients with } \\
\text { missing DMSA or VCUG were excluded }\end{array}$} \\
\hline \multicolumn{4}{|l|}{ Comparative } \\
\hline Notes & \multicolumn{3}{|c|}{$\begin{array}{l}\text { Those with increased bladder wall thickness were counted as hav- } \\
\text { ing an abnormal renal ultrasound }\end{array}$} \\
\hline \multicolumn{4}{|l|}{ Methodological quality } \\
\hline Item & $\begin{array}{l}\text { Authors' judge- } \\
\text { ment }\end{array}$ & Risk of bias & $\begin{array}{l}\text { Applicability con- } \\
\text { cerns }\end{array}$ \\
\hline \multicolumn{4}{|l|}{ DOMAIN 1: Patient Selection } \\
\hline Was a consecutive or random sample of patients enrolled? & Yes & & \\
\hline Was a case-control design avoided? & Yes & & \\
\hline \multirow[t]{2}{*}{ Did the study avoid inappropriate exclusions? } & Yes & & \\
\hline & & Low & High \\
\hline
\end{tabular}

\section{DOMAIN 2: Index Test Ultrasound}

Were the index test results interpreted without knowledge of Yes the results of the reference standard?

\begin{tabular}{lccc}
\hline If a threshold was used, was it pre-specified? & Yes & \\
\hline & Low & High \\
\hline
\end{tabular}

\section{DOMAIN 2: Index Test DMSA}

Were the index test results interpreted without knowledge of Yes the results of the reference standard? 
Tsai 2012 (Continued)

\begin{tabular}{lcl}
\hline & Low & Low \\
\hline DOMAIN 3: Reference Standard &
\end{tabular}

\section{DOMAIN 3: Reference Standard}

Is the reference standards likely to correctly classify the target Yes condition?

Were the reference standard results interpreted without knowl- Yes edge of the results of the index tests?

Low Low

\section{DOMAIN 4: Flow and Timing}

Was there an appropriate interval between index test and refer- Yes ence standard?

\begin{tabular}{ll}
\hline Did all patients receive the same reference standard? & Yes \\
\hline Were all patients included in the analysis? & No \\
\hline
\end{tabular}

Low

Tseng 2007

\section{Study characteristics}

\begin{tabular}{ll}
\hline Patient sampling & $\begin{array}{l}\text { Retrospective study of patients with complete radiological evalua- } \\
\text { tion }\end{array}$ \\
\hline Patient characteristics and setting & 232 children aged $<2$ years admitted with a first episode of UTI \\
\hline Index tests & DMSA \\
\hline Target condition and reference standard(s) & VUR, VCUG \\
\hline Flow and timing & DMSA 48 hours after diagnosis; VCUG 1 month after diagnosis; \\
\hline Comparative & \\
\hline Notes & \\
\hline
\end{tabular}

\section{Methodological quality}

\begin{tabular}{llll}
\hline Item & $\begin{array}{l}\text { Authors' judge- } \\
\text { ment }\end{array}$ & Risk of bias & $\begin{array}{l}\text { Applicability con- } \\
\text { cerns }\end{array}$ \\
\hline
\end{tabular}

\section{DOMAIN 1: Patient Selection}

Was a consecutive or random sample of patients enrolled?

No 
Tseng 2007 (Continued)

Was a case-control design avoided?

\begin{tabular}{llll}
\hline DOMAIN 2: Index Test All tests & High & Low \\
\hline $\begin{array}{l}\text { Were the index test results interpreted without knowledge of } \\
\text { the results of the reference standard? }\end{array}$ & Yes & Low \\
\hline If a threshold was used, was it pre-specified? & & Low \\
\hline
\end{tabular}

\section{DOMAIN 3: Reference Standard}

Is the reference standards likely to correctly classify the target Yes condition?

Were the reference standard results interpreted without knowl- Unclear edge of the results of the index tests?

\section{DOMAIN 4: Flow and Timing}

Was there an appropriate interval between index test and refer- Yes ence standard?

Did all patients receive the same reference standard?

Yes

Were all patients included in the analysis?

No

High

Zaki 1996

\section{Study characteristics}

\begin{tabular}{ll}
\hline Patient sampling & Prospective \\
\hline Patient characteristics and setting & $\begin{array}{l}50 \text { children aged } 6 \text { months to } 12 \text { years admitted with a first febrile } \\
\text { UTI }\end{array}$ \\
\hline Index tests & DMSA \\
\hline Target condition and reference standard(s) & VUR, VCUG \\
\hline Flow and timing & $\begin{array}{l}\text { DMSA within } 1 \text { week of admission; VCUG 2 to 4 weeks after presen- } \\
\text { tation }\end{array}$ \\
\hline
\end{tabular}

\section{Comparative}


Zaki 1996 (Continued)

Notes

\section{Methodological quality}

\begin{tabular}{llll}
\hline Item & $\begin{array}{l}\text { Authors' judge- } \\
\text { ment }\end{array}$ & Risk of bias & $\begin{array}{l}\text { Applicability con- } \\
\text { cerns }\end{array}$
\end{tabular}

\section{DOMAIN 1: Patient Selection}

\begin{tabular}{ll} 
Was a consecutive or random sample of patients enrolled? & Unclear \\
\hline Was a case-control design avoided? & Yes \\
\hline Did the study avoid inappropriate exclusions? & Yes
\end{tabular}

\begin{tabular}{lll}
\hline Low & Low \\
\hline
\end{tabular}

\section{DOMAIN 2: Index Test All tests}

Were the index test results interpreted without knowledge of Yes the results of the reference standard?

If a threshold was used, was it pre-specified?

Yes

\begin{tabular}{lcc}
\hline & Low & Low \\
\hline DOMAIN 3: Reference Standard &
\end{tabular}

\section{DOMAIN 3: Reference Standard}

Is the reference standards likely to correctly classify the target Yes condition?

Were the reference standard results interpreted without knowl- Unclear edge of the results of the index tests?

\begin{tabular}{lll}
\hline & Low & Low \\
\hline DOMAIN 4: Flow and Timing & & \\
\hline $\begin{array}{l}\text { Was there an appropriate interval between index test and refer- } \\
\text { ence standard? }\end{array}$ & Yes \\
\hline Did all patients receive the same reference standard? & Yes \\
\hline Were all patients included in the analysis? &
\end{tabular}

Low

\section{Zaki 2003}

\section{Study characteristics}

\begin{tabular}{ll}
\hline Patient sampling & Retrospective \\
\hline Patient characteristics and setting & 174 children aged 0 to 12 years admitted with first febrile UTI, high \\
& CRP $(>40 \mathrm{mg} / \mathrm{L})$ and had DMSA and VCUG; however, DMSA was \\
\hline
\end{tabular}


Zaki 2003 (Continued)

standard of care and VCUG was only missing in 7 patients; exclusion based on ethnicity

\begin{tabular}{lll}
\hline Index tests & DMSA & VUR, VCUG \\
\hline Target condition and reference standard(s) & $\begin{array}{l}\text { DMSA within 1 week of admission; VCUG at least 1 month after in- } \\
\text { fection }\end{array}$ \\
\hline Flow and timing & \\
\hline Comparative & $\begin{array}{l}\text { Authors' judge- } \\
\text { ment }\end{array}$ & Risk of bias \\
\hline Notes & Applicability con- \\
\hline Methodological quality & cerns \\
\hline Item & Yes \\
\hline DomAIN 1: Patient Selection & Yes \\
\hline Was a consecutive or random sample of patients enrolled? & Yes & Low \\
\hline Was a case-control design avoided? & High \\
\hline Did the study avoid inappropriate exclusions? & & \\
\hline
\end{tabular}

\section{DOMAIN 2: Index Test All tests}

Were the index test results interpreted without knowledge of Yes the results of the reference standard?

If a threshold was used, was it pre-specified?

Yes

\begin{tabular}{lll}
\hline Low & Low \\
\hline
\end{tabular}

DOMAIN 3: Reference Standard

Is the reference standards likely to correctly classify the target Yes condition?

Were the reference standard results interpreted without knowl- Unclear edge of the results of the index tests?

Low

Low

\section{DOMAIN 4: Flow and Timing}

Was there an appropriate interval between index test and refer- Unclear ence standard?

Did all patients receive the same reference standard?

Yes

Were all patients included in the analysis?

Yes 
Zaki 2003 (Continued)

APN - acute pyelonephritis; CRP - C-reactive protein; DMSA - 99Tc-dimercaptosuccinic acid; ESR - erythrocyte sedimentation rate; SPECT - single-photon emission computed tomography; US - ultrasound; UTI - urinary tract infection; VCUG - voiding cystourethrography; VUR vesicoureteric reflux; WBC - white blood cell

Characteristics of excluded studies [ordered by study ID]

\begin{tabular}{|c|c|}
\hline Study & Reason for exclusion \\
\hline Adibi 2013 & UTI definition not specified \\
\hline Ahmadzadeh 2007 & UTI definition not met \\
\hline Ajdinovic 2005 & DMSA timing not given \\
\hline Ajdinovic 2006 & DMSA timing not given \\
\hline Ajdinovic 2008 & DMSA performed later than 1 month \\
\hline Ajdinovic 2010 & Not enough data to calculate sensitivity/specificity \\
\hline Aktas 2008 & DMSA performed later than 1 month \\
\hline Almeida 1994 & UTI definition not met \\
\hline Alshamsam 2009 & UTI definition not met \\
\hline Alvarez 2009 & Not relevant \\
\hline Alzen 1994 & Not all patients had a UTI \\
\hline Asanuma 2012 & Not enough data to calculate sensitivity/specificity \\
\hline Balbay 1998 & UTI definition not specified \\
\hline Barros 2010 & VCUG only in high-risk children \\
\hline Beiraghdar 2012 & Not enough data to calculate sensitivity/specificity \\
\hline Ben-Ami 1989 & Not enough data to calculate sensitivity/specificity \\
\hline Benador 1994 & Not enough data to calculate sensitivity/specificity \\
\hline Benador 1997 & UTI definition not met \\
\hline Benador 1998 & UTI definition not met \\
\hline Benador 2001 & UTI definition not met \\
\hline Bergius 1990 & UTI definition not specified \\
\hline Berry 2012 & UTI definition not specified \\
\hline
\end{tabular}




\begin{tabular}{|c|c|}
\hline Study & Reason for exclusion \\
\hline Bhatnagar 2002 & UTI definition not specified \\
\hline Biggi 2001 & Not enough data to calculate sensitivity/specificity \\
\hline Biyikli 2004 & Not enough data to calculate sensitivity/specificity \\
\hline Blane 1993 & Not all patients had a UTI \\
\hline Boudailliez 1989 & Gold standard was not radiographic VCUG \\
\hline Bouissou 1988 & Not enough data to calculate sensitivity/specificity \\
\hline Bouissou 1994 & DMSA performed later than 1 month \\
\hline Butorac-Ahel 2011 & Not enough data to calculate sensitivity/specificity \\
\hline Cabezuelo Huerta 2005 & UTI definition not specified \\
\hline Caillaud 2013 & Not enough data to calculate sensitivity/specificity \\
\hline Calleja Gero 2008 & Not enough data to calculate sensitivity/specificity \\
\hline Castello Girona 1995 & UTI definition not met \\
\hline Cemerlic-Zecevic 2002 & DMSA performed later than 1 month \\
\hline Cheng 2011 & Not enough data to calculate sensitivity/specificity \\
\hline Chroustova 2006 & DMSA performed later than 1 month \\
\hline Clarke 1996 & DMSA timing not given \\
\hline Cortes 2010 & Not enough data to calculate sensitivity/specificity \\
\hline Craig 1998 & UTI definition not met \\
\hline D'Souza 2013 & Enhanced ultrasound \\
\hline David 1998 & Not all patients had a UTI \\
\hline De Mutiis 2011 & Not enough data to calculate sensitivity/specificity \\
\hline DiPietro 1997 & UTI definition not specified \\
\hline Ditchfield 1994 & Index test is Tc-99gluconate, not DMSA \\
\hline Ditchfield 1998 & DMSA timing not given \\
\hline Donoso 2012 & DMSA performed later than 1 month \\
\hline Dura Trave 1997 & UTI definition not specified \\
\hline Ekim 1992 & Not enough data to calculate sensitivity/specificity \\
\hline El-Naggari 2011 & Not enough data to calculate sensitivity/specificity \\
\hline
\end{tabular}




\begin{tabular}{|c|c|}
\hline Study & Reason for exclusion \\
\hline Elison 1992 & DMSA timing not given \\
\hline Fallahzadeh 2008 & UTI definition not specified \\
\hline Farnsworth 1991 & DMSA performed later than 1 month \\
\hline Fidan 2013 & Not enough data to calculate sensitivity/specificity \\
\hline Foresman 2001 & UTI definition not met \\
\hline Fouzas 2010 & Gold standard was not radiographic VCUG \\
\hline Gelfand 2000 & UTI definition not specified \\
\hline Geronikola-Trapali 2010 & Not enough data to calculate sensitivity/specificity \\
\hline Ghiro 2002 & UTI definition not met \\
\hline Giorgi 2005 & UTI definition not specified \\
\hline Gomez Tellado 1994 & Not enough data to calculate sensitivity/specificity \\
\hline Gupta 2011 & Not enough data to calculate sensitivity/specificity \\
\hline Halevy 2013 & Not enough data to calculate sensitivity/specificity \\
\hline Hamoui 2008 & Not enough data to calculate sensitivity/specificity \\
\hline Hannula 2009 & Not enough data to calculate sensitivity/specificity \\
\hline Hannula 2010 & Not enough data to calculate sensitivity/specificity \\
\hline Hannula 2011 & UTI definition not specified \\
\hline Hansson 1997 & Not enough data to calculate sensitivity/specificity \\
\hline Hansson 2004 & DMSA performed later than 1 month \\
\hline Haznedaroglu 1996 & UTI definition not specified \\
\hline Herz 2005 & Not enough data to calculate sensitivity/specificity \\
\hline Herz 2010 & UTI definition not specified \\
\hline Hiraoka 1996 & Not enough data to calculate sensitivity/specificity \\
\hline Hiraoka 1997 & Not enough data to calculate sensitivity/specificity \\
\hline Honkinen 1986 & Gold standard not radiographic VCUG \\
\hline Huang 2008 & UTI definition not met \\
\hline Inoue 2011 & Not enough data to calculate sensitivity/specificity \\
\hline Jakobsson 1996 & Not enough data to calculate sensitivity/specificity \\
\hline
\end{tabular}




\begin{tabular}{|c|c|}
\hline Study & Reason for exclusion \\
\hline Jakobsson 1997 & UTI definition not specified \\
\hline Jarmolinski 2011 & Not enough data to calculate sensitivity/specificity \\
\hline Jaukovic 2009 & DMSA performed later than 1 month \\
\hline Jequier 1985 & UTI definition not specified \\
\hline Jewkes 1990 & UTI definition not specified \\
\hline Johnson 1985 & UTI definition not met \\
\hline Johnson 1986 & UTI definition not met \\
\hline Juliano 2013 & UTI definition not specified \\
\hline Kanellopoulos 2005 & Not enough data to calculate sensitivity/specificity \\
\hline Kanellopoulos 2006 & UTI definition not met \\
\hline Kangarloo 1985 & Not enough data to calculate sensitivity/specificity \\
\hline Kaplan Bulut 2011 & Not enough data to calculate sensitivity/specificity \\
\hline Kass 1992 & Index test is TC-glucoheptonate, not DMSA \\
\hline Kass 2000 & UTI definition not specified \\
\hline Kim 2010 & Not enough data to calculate sensitivity/specificity \\
\hline Kljucevsek 2009 & Enhanced ultrasound \\
\hline Krzemien 2002 & UTI definition not met \\
\hline Kuzmanovska 2008 & Gold standard was not radiographic VCUG \\
\hline La Scola 2013 & UTI definition not specified \\
\hline Lee $2009 b$ & Not all patients had a UTI \\
\hline Lee $2012 b$ & Not all patients had a UTI \\
\hline Leroy 2010 & Not enough data to calculate sensitivity/specificity \\
\hline $\operatorname{Lim} 2010$ & UTI definition not specified \\
\hline Lin 2003 & Gold standard was not uniformly VCUG \\
\hline Lytzen 2011 & Not enough data to calculate sensitivity/specificity \\
\hline MacLeod 2011 & Not enough data to calculate sensitivity/specificity \\
\hline Mage 1989 & UTI definition not specified \\
\hline Majd 1991 & Gold standard was not uniformly VCUG \\
\hline
\end{tabular}




\begin{tabular}{|c|c|}
\hline Study & Reason for exclusion \\
\hline Martin Aguado 2000 & Not enough data to calculate sensitivity/specificity \\
\hline Martinez 2012 & DMSA timing not given \\
\hline Masalskiene 2011 & UTI definition not specified \\
\hline Massanyi 2013 & Gold standard not radiographic VCUG \\
\hline Matesanz 1998 & Not all patients had UTI \\
\hline Mazigh Mrad 2002 & Not relevant (no VCUG) \\
\hline Merguerian 1999 & DMSA performed later than 1 month \\
\hline Mersdorf 1997 & Not enough data to calculate sensitivity/specificity \\
\hline Mingin 2004 & DMSA performed later than 1 month \\
\hline Mohkam 2010 & Not enough data to calculate sensitivity/specificity \\
\hline Mohkam 2012 & UTI definition not specified \\
\hline Monakil 2013 & UTI definition not specified \\
\hline Montini 2008 & Not enough data to calculate sensitivity/specificity \\
\hline Moon 2009 & Not enough data to calculate sensitivity/specificity \\
\hline Muensterer 2002 & Not all patients had a UTI \\
\hline Muga Zuriarrain 2008 & DMSA performed later than 1 month \\
\hline Nafisi-Moghadam 2011 & UTI definition not specified \\
\hline Nammalwar 2005 & UTI definition not specified \\
\hline Naseri 2013 & Not enough data to calculate sensitivity/specificity \\
\hline Nelson 2013 & UTI definition not specified \\
\hline Ninos 1998 & Not all patients had UTI \\
\hline Orive 2010 & UTI definition not specified \\
\hline Otukesh 2011 & Enhanced ultrasound \\
\hline Otukesh 2013 & Not enough data to calculate sensitivity/specificity \\
\hline Paripovic 2010 & Not enough data to calculate sensitivity/specificity \\
\hline Pecile 1999 & Gold standard was not uniformly VCUG \\
\hline Pecile 2009 & Gold standard was not uniformly VCUG \\
\hline Pennesi 2012 & VCUG only in high-risk children \\
\hline
\end{tabular}




\begin{tabular}{|c|c|}
\hline Study & Reason for exclusion \\
\hline Printza 2012 & Gold standard was not radiographic VCUG \\
\hline Puseljic 2003 & UTI definition not met \\
\hline Quirino 2011 & UTI definition not specified \\
\hline Radmayr 2001 & Enhanced ultrasound \\
\hline Radmayr 2002 & UTI definition not specified \\
\hline Risi 1990 & Not enough data to calculate sensitivity/specificity \\
\hline Ristola 2013 & Not enough data to calculate sensitivity/specificity \\
\hline Rosenberg 1990 & UTI definition not specified \\
\hline Rosenberg 1992 & Not enough data to calculate sensitivity/specificity \\
\hline Sadeghi-bojd 2013 & Not enough data to calculate sensitivity/specificity \\
\hline Schiavina 1988 & UTI definition not specified \\
\hline Schneider 1986 & Not all patients had a UTI \\
\hline Schneider 1997 & DMSA performed later than 1 month \\
\hline Sciagra 1996 & DMSA timing not given \\
\hline Sinha 2013 & Not enough data to calculate sensitivity/specificity \\
\hline Siomou 2009 & Gold standard was not radiographic VCUG \\
\hline Smellie 1995 & UTI definition not specified \\
\hline Soccorso 2010 & Less than $1 / 5$ patients had a VCUG \\
\hline Sorkhi 2010 & Not all patients had a UTI \\
\hline Sreenarasimhaiah 1995 & Not enough data to calculate sensitivity/specificity \\
\hline Stokland 1996 & DMSA performed later than 1 month \\
\hline Strife 1989 & UTI definition not specified \\
\hline Subat-Dezulovic 1998 & Not relevant (no data on index test or gold standard) \\
\hline Sun 2013 & Not enough data to calculate sensitivity/specificity \\
\hline Supavekin 2013b & Not enough data to calculate sensitivity/specificity \\
\hline Taheri 2013 & $\begin{array}{l}\text { Only } 50 \% \text { of patients had a VCUG. Methods do not adequately explain why. Timing of imaging } \\
\text { tests not specified. Numbers in tables do not match. Bladder thickness used to define an abnormal } \\
\text { ultrasound and many children with this finding. No age range. }\end{array}$ \\
\hline Tan 1988 & UTI definition not met \\
\hline
\end{tabular}




\begin{tabular}{|c|c|}
\hline Study & Reason for exclusion \\
\hline Tappin 1989 & Not enough data to calculate sensitivity/specificity \\
\hline Temiz 2006 & Not all patients had a UTI \\
\hline Teoh 2011 & DMSA timing not given \\
\hline Tepmongkol 2002 & Gold standard was not uniformly VCUG \\
\hline Tramma 2010 & UTI definition not specified \\
\hline Tsai 2004 & Not relevant \\
\hline Tse 2009 & UTI definition not specified \\
\hline Valavi 2011 & Not enough data to calculate sensitivity/specificity \\
\hline Venhola 2010 & UTI definition not specified \\
\hline Verber 1988 & DMSA timing not given \\
\hline Wong 2010 & UTI definition not specified \\
\hline Wongbencharat 2013 & Not enough data to calculate sensitivity/specificity \\
\hline Wu 2004 & Gold standard was not radiographic VCUG \\
\hline Wu 2011 & Gold standard was not radiographic VCUG \\
\hline Zaki 2005 & DMSA performed later than 1 month \\
\hline Zhang 2010 & UTI definition not specified \\
\hline Zhang 2013 & UTI definition not specified \\
\hline Zhang 2014 & Not all patients had a UTI \\
\hline Zhao 2006 & Gold standard not a radiographic VCUG (radionuclide); no UTI definition \\
\hline Zocchi 1988 & UTI definition not specified \\
\hline
\end{tabular}

DMSA - 99TC-dimercaptosuccinic acid; UTI - urinary tract infection; VCUG - voiding cystourethrography; VUR - vesicoureteric reflux

Characteristics of studies awaiting classification [ordered by study ID]

\section{Alvarez 2007}

\section{Study characteristics}

Patient sampling

Patient characteristics and setting

Index tests 
Alvarez 2007 (Continued)

Target condition and reference standard(s)

Flow and timing

Comparative

Notes Cannot obtain full text of article

\section{Maioli 1987}

\section{Study characteristics}

Patient sampling

Patient characteristics and setting

Index tests

Target condition and reference standard(s)

Flow and timing

Comparative

Notes Cannot obtain full text of article

\section{A T A}

Presented below are all the data for all of the tests entered into the review.

\section{Table Tests. Data tables by test}

\begin{tabular}{lll}
\hline Test & No. of studies & No. of participants \\
\hline 1 Ultrasound & 20 & 3726 \\
\hline 2 Ultrasound for high-grade VUR & 11 & 2498 \\
\hline 3 Ultrasound Renal Units & 1 & 200 \\
\hline 4 Ultrasound for high-grade VUR (Renal Units) & 200 \\
\hline 5 DMSA & 1 & 3863 \\
\hline 6 DMSA for high-grade VUR & 19 & 2499 \\
\hline 7 DMSA Renal-Units & 10 & 1907 \\
\hline 8 DMSA for high-grade VUR (Renal Units) & 9 & 642 \\
\hline
\end{tabular}


Test 1. Ultrasound.

Review: Dimercaptosuccinic acid scan or ultrasound in screening for vesicoureteral reflux among children with urinary tract infections
Test: 1 Ultrasound

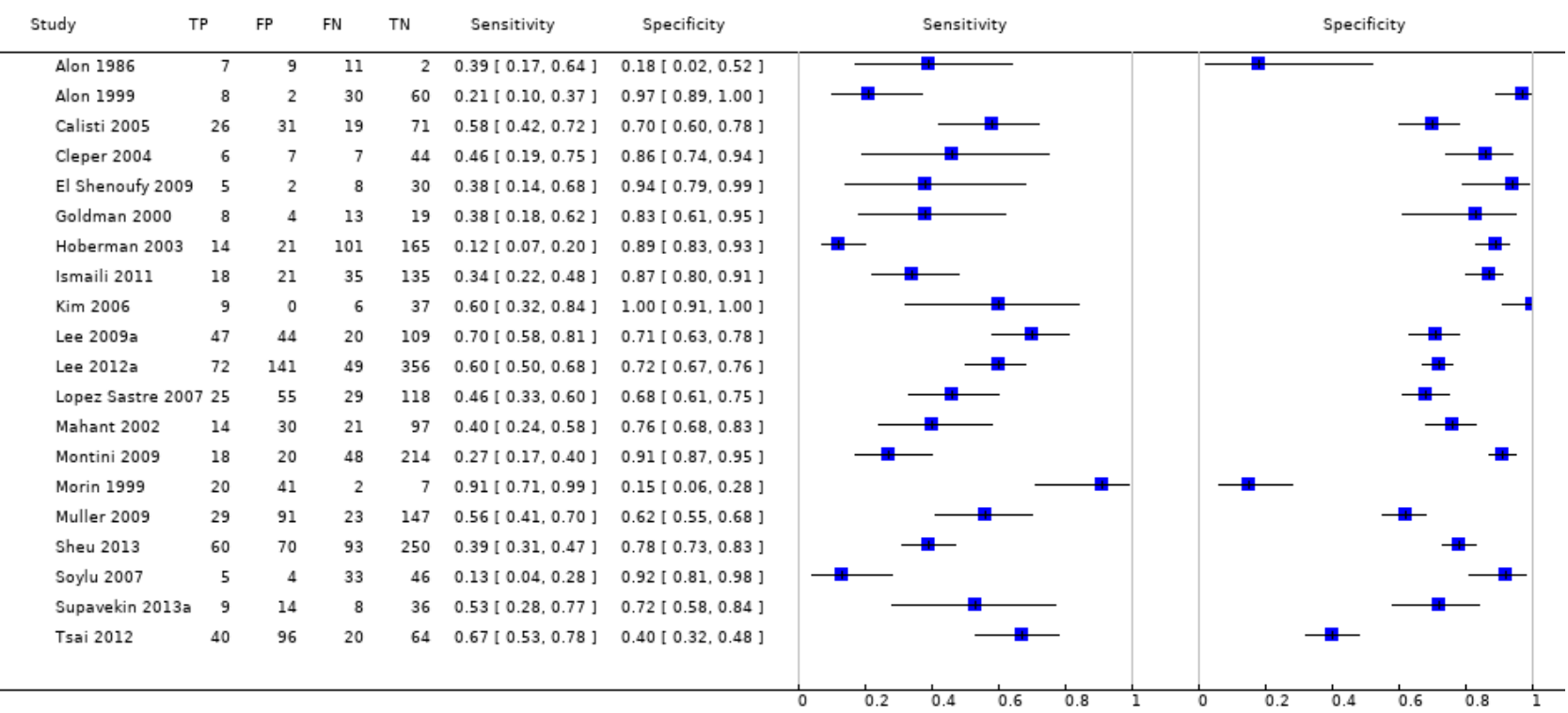

Test 2. Ultrasound for high-grade VUR.

Review: Dimercaptosuccinic acid scan or ultrasound in screening for vesicoureteral reflux among children with urinary tract infections
Test: 2 Ultrasound for high-grade VUR

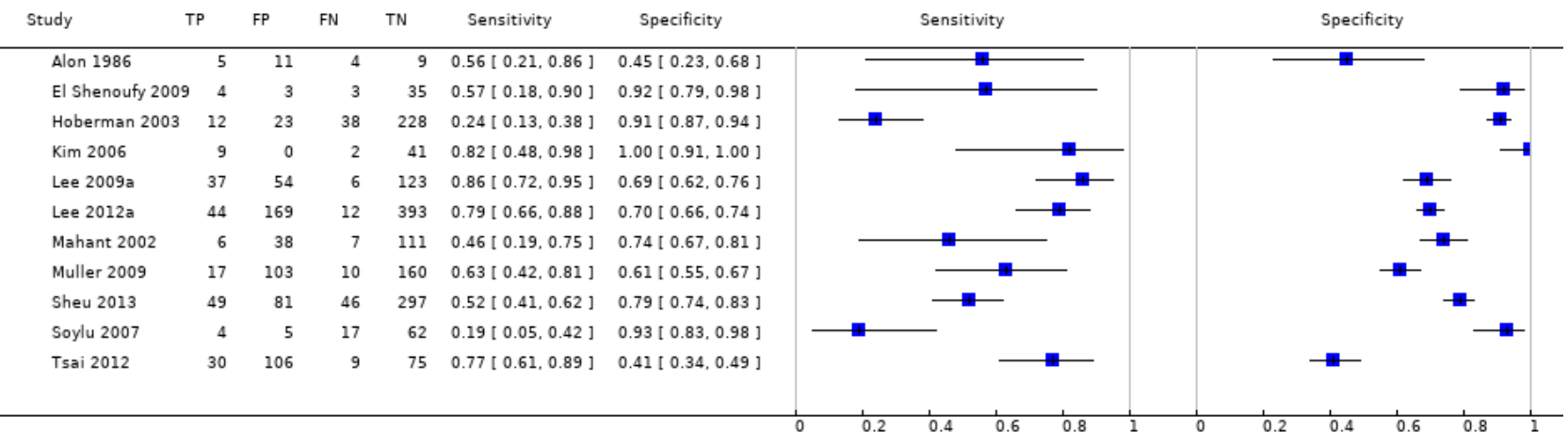

Test 3. Ultrasound Renal Units.

Review: Dimercaptosuccinic acid scan or ultrasound in screening for vesicoureteral reflux among children with urinary tract infections
Test: 3 Ultrasound Renal Units

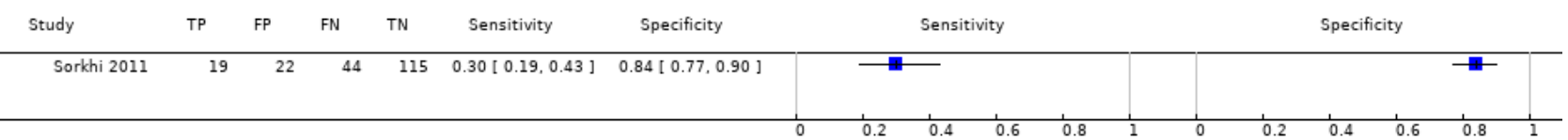


Test 4. Ultrasound for high-grade VUR (Renal Units). Review: Dimercaptosuccinic acid scan or ultrasound in screening for vesicoureteral reflux among children with urinary tract infections
Test: 4 Ultrasound for high-grade VUR (Renal Units)

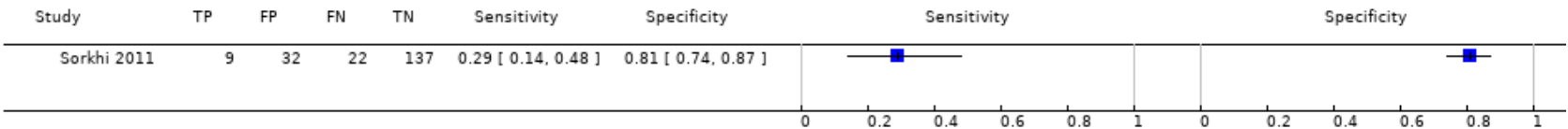

Test 5. DMSA.

Review: Dimercaptosuccinic acid scan or ultrasound in screening for vesicoureteral reflux among children with urinary tract infections
Test: 5 DMSA

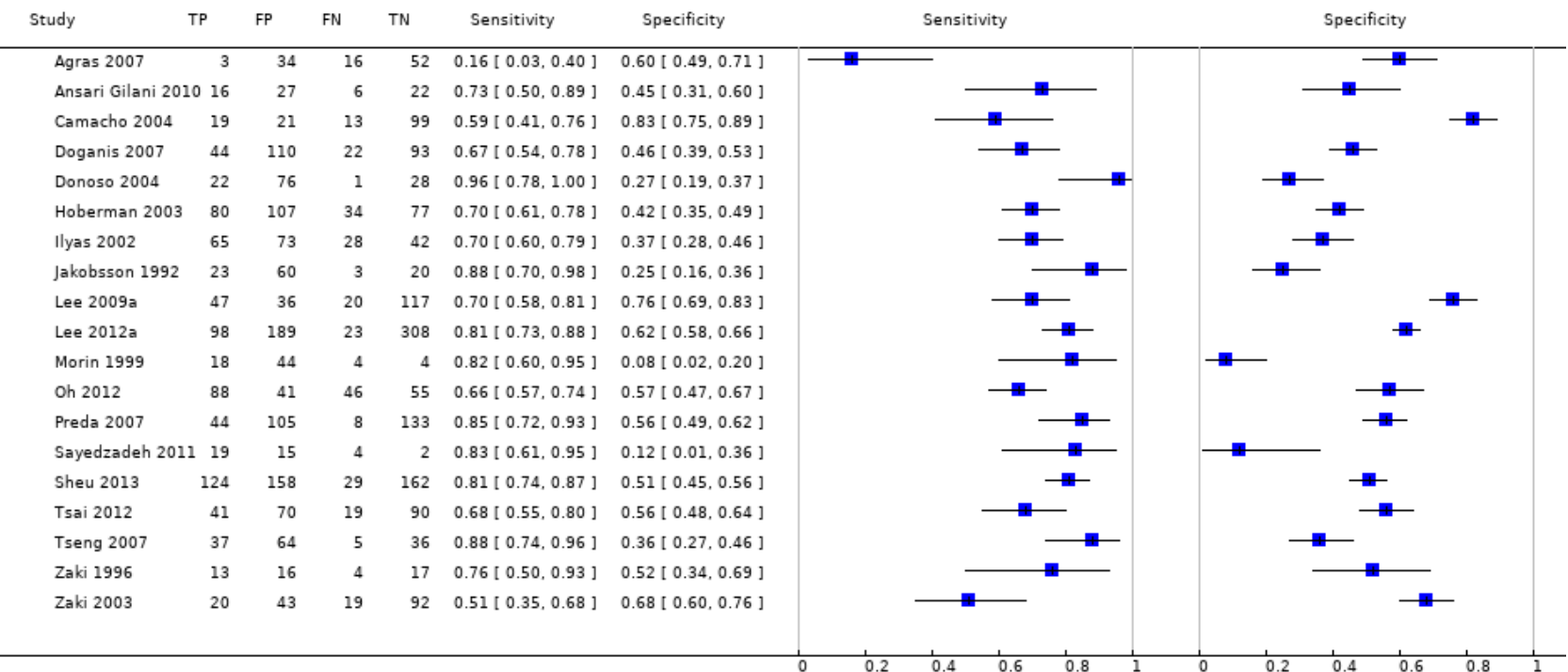

Test 6. DMSA for high-grade VUR.

Review: Dimercaptosuccinic acid scan or ultrasound in screening for vesicoureteral reflux among children with urinary tract infections

\begin{tabular}{|c|c|c|c|c|c|c|c|c|}
\hline Study & TP & $\mathrm{FP}$ & $\mathrm{FN}$ & $\mathrm{TN}$ & Sensitivity & Specificity & Sensitivity & Specificity \\
\hline Agras 2007 & 2 & 35 & 10 & 58 & $0.17[0.02,0.48]$ & $0.62[0.52,0.72]$ & 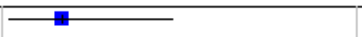 & 5 \\
\hline Donoso 2004 & 9 & 89 & 0 & 29 & $1.00[0.66,1.00]$ & $0.25[0.17,0.33]$ & $\longrightarrow$ & $\rightarrow-$ \\
\hline Hoberman 2003 & 33 & 154 & 16 & 95 & $0.67[0.52,0.80]$ & $0.38[0.32,0.44]$ & $\longrightarrow$ & - \\
\hline Jakobsson 1992 & 14 & 69 & 1 & 22 & $0.93[0.68,1.00]$ & $0.24[0.16,0.34]$ & - & - \\
\hline Lee 2009a & 38 & 45 & 5 & 132 & $0.88[0.75,0.96]$ & $0.75[0.67,0.81]$ & $=$ & $\rightarrow-$ \\
\hline Lee 2012a & 55 & 232 & 1 & 330 & $0.98[0.90,1.00]$ & $0.59[0.55,0.63]$ & $\rightarrow$ & - \\
\hline Muller 2009 & 26 & 123 & 1 & 40 & $0.96[0.81,1.00]$ & $0.25[0.18,0.32]$ & $=$ & - \\
\hline Sheu 2013 & 91 & 191 & 4 & 187 & $0.96[0.90,0.99]$ & $0.49[0.44,0.55]$ & 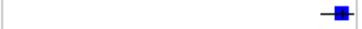 & 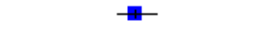 \\
\hline Tsai 2012 & 32 & 79 & 7 & 102 & $0.82[0.66,0.92]$ & $0.56[0.49,0.64]$ & $=$ & $\rightarrow-$ \\
\hline Tseng 2007 & 21 & 80 & 0 & 41 & $1.00[0.84,1.00]$ & $0.34[0.26,0.43]$ & $\longrightarrow$ & - \\
\hline
\end{tabular}


Test 7. DMSA Renal-Units.

Review: Dimercaptosuccinic acid scan or ultrasound in screening for vesicoureteral reflux among children with urinary tract infections
Test: 7 DMSA Renal-Units

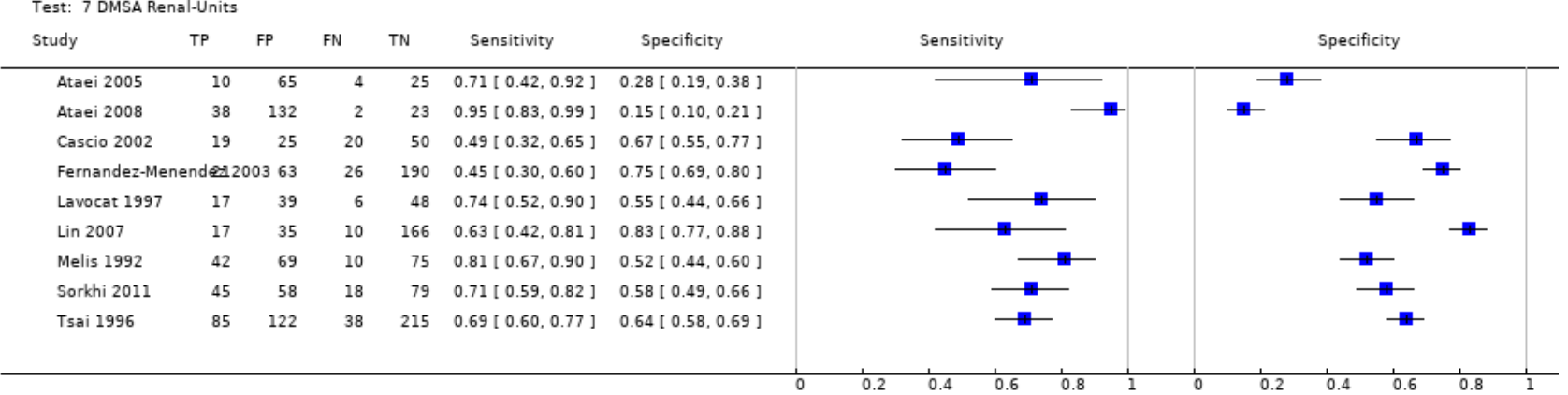

Test 8. DMSA for high-grade VUR (Renal Units).

Review: Dimercaptosuccinic acid scan or ultrasound in screening for vesicoureteral reflux among children with urinary tract infections

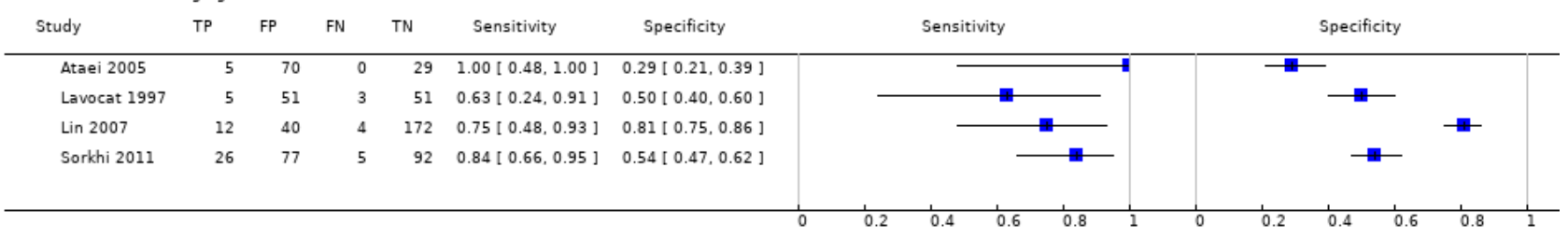

\section{APPENDICES}

\section{Appendix 1. Electronic search strategies}

\begin{tabular}{ll}
\hline Database & Search terms \\
\hline MEDLINE & 1. exp Succimer/ \\
2. Organotechnetium Compounds/ & 3. Organometallic Compounds/ and Technetium/ \\
4. Radionuclide Imaging/ & 5. DMSA.tw. \\
6. dimercaptosuccin\$.tw. \\
7. dimercapto-succin\$.tw. \\
8. scintigra\$.tw. \\
9. Ultrasonography/ \\
10.exp Ultrasonography, Doppler/ \\
11.Ultrasonography, Interventional/ \\
12.(ultrasound or ultrasonogra\$ or echogr\$ or sonogr\$).tw. \\
13.or/1-12 \\
14.Vesico-Ureteral Reflux/ \\
15.vesicoureteral reflux.tw. \\
16.vesico-ureteral reflux.tw. \\
17.VUR.tw. \\
18.or/14-17 \\
19. and/13,18
\end{tabular}

Dimercaptosuccinic acid scan or ultrasound in screening for vesicoureteral reflux among children with urinary tract infections (Review) 
20.Vesico-Ureteral Reflux/ri

21.Vesico-Ureteral Reflux/us

22.Vesico-Ureteral Reflux/ and "Sensitivity and Specificity"/

23.or $/ 20-22$

24.or/19,23

25.exp Infant/ or exp Child/ or Adolescent/ or exp Puberty/ or Pediatrics/ or exp Schools/

26. (infant* or infancy or newborn* or baby or babies or neonat* or preterm or prematur* or postmatur $^{\star}$ or child $^{\star}$ or schoolchild ${ }^{\star}$ or school age ${ }^{\star}$ or preschool* or kid or kids or toddler ${ }^{\star}$ or adolesc $^{\star}$ or teen* or boy* or girl* or minor or minors or pubert* or pubescen* or prepubescen* or paediatric $^{\star}$ or pediatric ${ }^{\star}$ or nursery school ${ }^{\star}$ or kindergar ${ }^{\star}$ or primary school ${ }^{\star}$ or secondary school* or elementary school* or high school* or highschool*).tw.

27.or/25-26

28.and $/ 24,27$
1. succimer tc $99 \mathrm{~m} /$

2. succimer/

3. (dimercaptosuccin\$ or dimercapto-succin\$).tw.

4. DMSA.tw.

5. Scintigraphy/

6. scintigra\$.tw.

7. Scintiscanning/

8. Radioisotope Diagnosis/

9. Echography/

10.Doppler Echography/

11.Echotomography/

12. (ultrasound or ultrasonogr\$ or echogr\$ or sonogr\$).tw.

13.or/1-12

14.vesicoureteral reflux/

15.vesicoureteral reflux.tw.

16.vesico-ureteral reflux.tw.

17.VUR.tw.

18.or/14-17

19.and $/ 13,18$

20.vesicoureteral reflux/ and (diagnostic test accuracy/ or "sensitivity and specificity"/)

21.or/19-20

22.exp Child/

23.exp Infant/

24.Adolescent/

25.exp Adolescence/

26.school/

27.pediatrics/

28.child urology/

29. (infant* or infancy or newborn* or baby or babies or neonat ${ }^{\star}$ or preterm or prematur ${ }^{\star}$ or post-

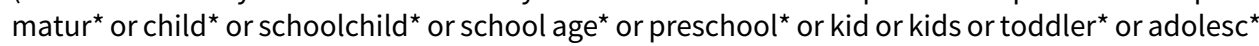
or teen ${ }^{\star}$ or boy ${ }^{\star}$ or girl ${ }^{\star}$ or minor or minors or pubert ${ }^{\star}$ or pubescen ${ }^{\star}$ or prepubescen ${ }^{\star}$ or paediatric ${ }^{\star}$ or pediatric ${ }^{\star}$ or nursery school* or kindergar $^{\star}$ or primary school ${ }^{\star}$ or secondary school* or elementary school* or high school* or highschool*).tw.

30.or/22-29

31.and $/ 21,30$

BIOSIS

\section{TS=dimercaptosuccin * \\ 2. TS=dimercapto-succin* \\ 3. TS=scintigra*}




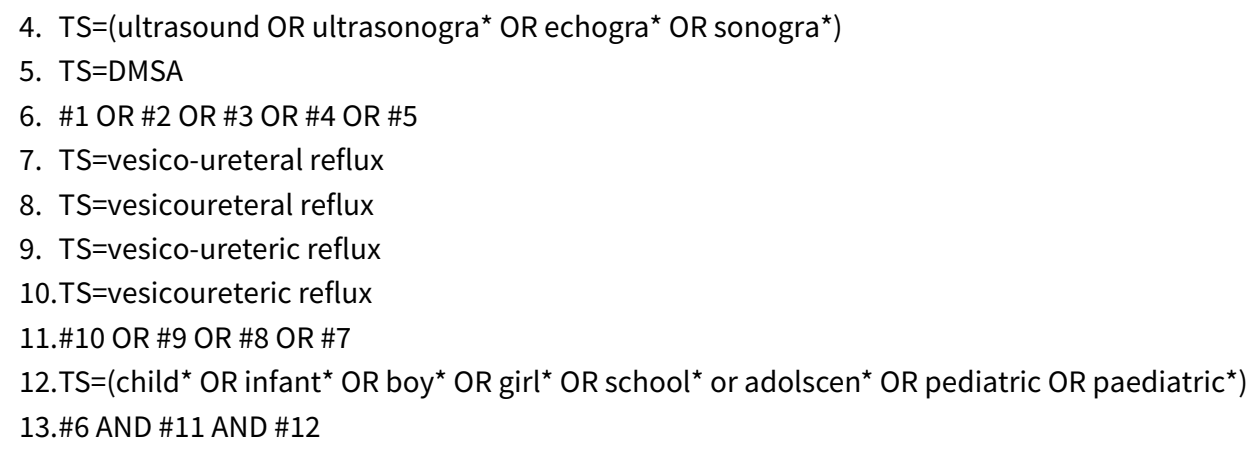

Cochrane Register of Diagnostic Test Accuracy Studies
1. Urinary tract infection
2. VUR
3. Vesicoureteral reflux
4. \#1 or \#2 or \#3

\section{Appendix 2. QUADAS-2}

\section{Domain 1: Patient selection}

A study was deemed as having a "high risk of bias" for this domain if:

1. The study was retrospective and included a convenience sample of patients who happened to have the index test of interest and the reference standard (i.e. the primary inclusion criteria was having had all relevant imaging tests, not having had a UTI). Because these studies were retrospective, bias cannot be ruled out. For example, performance of the reference standard may have been influenced by the results of the index test.

2. Excluded subgroups of children based on events occurring long after the diagnosis of UTI (e.g. recurrence of UTI)

A study was deemed as having a "high risk" for applicably if it Included only a subgroup of children with UTI.

1. Only patients in a restricted age range (e.g. neonates, one gender),

2. Only patients with elevated inflammatory markers (e.g. C-reactive protein, erythrocyte sedimentation rate),

3. Patients were markedly different from that of a cohort of children with UTI

4. Only high-risk patients referred for imaging

\section{Domain 2: Index test}

A study was deemed as having a "high risk of bias" for this domain if the test procedure was markedly different from usual practice or if a markedly unusual threshold was used. If the index test occurred before the reference standard, it was assumed to have been interpreted blindly. Because all studies except those which used a regular renal ultrasound and a DMSA scan as the reference standard were excluded, no studies were "high risk" for applicability.

\section{Domain 3: Reference standard}

A study was deemed as having a "high risk of bias" for this domain if the VCUG was not interpreted as per the International Reflux study criteria. Because the interpretation of the VCUG test is quite standardized, it is less prone to bias due to the lack of blinding. Accordingly, lack of blinding alone did not result in a "high risk of bias".

Because all studies included used the radiographic VCUG as the reference standard were excluded, no studies were "high risk" for applicability.

\section{Domain 4: Flow and timing}

A study was deemed as having a "high risk of bias" for this domain if

1. Not all patients received same reference standard OR

2. Excluded patients appear to have been excluded for reasons related to index test results (i.e. missing data not at random) OR

3. More than $20 \%$ of patients had missing data

Dimercaptosuccinic acid scan or ultrasound in screening for vesicoureteral reflux among children with urinary tract infections (Review) 
Because VUR is very slow to resolve (years) and because GU anomalies uncovered by ultrasound are similarly slow to resolve or are permanent, the timing of the VCUG and RBUS are not critical. All studies in which the DMSA was conducted $>30$ days were excluded. Thus, the timing of the tests in this review was of secondary importance.

\section{CONTRIBUTIONS OF AUTHORS}

1. Draft the protocol: NS, RS

2. Study selection: NS, RS, SH

3. Extract data from studies: NS, RS, SH

4. Enter data into RevMan: NS, RS, SH

5. Carry out the analysis: NS, RS

6. Interpret the analysis: NS, RS, SH

7. Draft the final review: NS, RS, SH

8. Disagreement resolution: NS, RS, SH

\section{DECLARATIONS OF INTEREST}

- Nader Shaikh: none known

- Russell B Spingarn: none known

- Stephanie W Hum: none known

\section{SOURCES OF SUPPORT}

\section{Internal sources}

- None, Namibia.

\section{External sources}

- None, Other.

\section{DIFFERENCES BETWEEN PROTOCOLANDREVIEW}

We changed the title of the review from "DMSA versus Ultrasound in screening for VUR among children with a UTI" to "DMSA or ultrasound in screening for VUR among children with UTIs". We also decided to include studies in which the timing of the VCUG or RBUS was unspecified. Almost all centres we are aware of conduct these tests within the first two months after the diagnosis of a UTI. Because the results of these tests are unlikely to change within this time period, the exact timing of these tests is of secondary interest only. We had stated that we would include only children $<18$ years of age. However, we later decided to include one study that included children up to 19 years of age. We did not search for ongoing studies. Because of the relatively small number of studies, meta-influence analysis was not performed. Although not specified in the protocol, we decided to include studies that reported data in terms of renal units.

\section{IN DEX TERMS}

\section{Medical Subject Headings (MeSH)}

*Radiopharmaceuticals; *Technetium Tc 99m Dimercaptosuccinic Acid; Cohort Studies; Cross-Sectional Studies; ROC Curve; Radionuclide Imaging; Sensitivity and Specificity; Severity of Illness Index; Ultrasonography; Urinary Tract Infections [*complications]; Vesico-Ureteral Reflux [complications] [*diagnostic imaging]

\section{MeSH check words}

Adolescent; Child; Child, Preschool; Humans; Infant; Infant, Newborn; Young Adult 